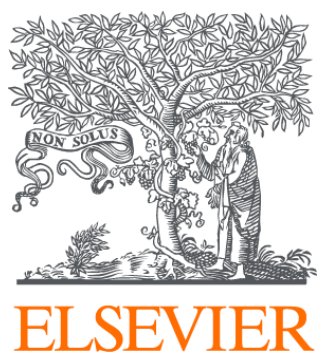

Since January 2020 Elsevier has created a COVID-19 resource centre with free information in English and Mandarin on the novel coronavirus COVID-

19. The COVID-19 resource centre is hosted on Elsevier Connect, the company's public news and information website.

Elsevier hereby grants permission to make all its COVID-19-related research that is available on the COVID-19 resource centre - including this research content - immediately available in PubMed Central and other publicly funded repositories, such as the WHO COVID database with rights for unrestricted research re-use and analyses in any form or by any means with acknowledgement of the original source. These permissions are granted for free by Elsevier for as long as the COVID-19 resource centre remains active. 


\title{
Revenge of the experts: Will COVID-19 renew or diminish public trust in science? ${ }^{\text {is }}$
}

\author{
Barry Eichengreen $^{\mathrm{a}, \mathrm{b}, \mathrm{c}}$, Cevat Giray Aksoy ${ }^{\mathrm{d}, \mathrm{e}, \mathrm{f}, *}$, Orkun Saka $^{\mathrm{g}, \mathrm{h}, \mathrm{i}}$ \\ aniversity of California, Berkeley, United States \\ ${ }^{\mathrm{b}}$ National Bureau of Economic Research, United States

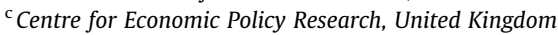 \\ ${ }^{\mathrm{d}}$ European Bank for Reconstruction and Development (EBRD), United Kingdom \\ ${ }^{\mathrm{e}}$ King's College London, United Kingdom \\ ${ }^{\mathrm{f}}$ IZA Institute of Labour Economics, Germany \\ ${ }^{\mathrm{g}}$ University of Sussex, United Kingdom \\ ${ }^{\mathrm{h}}$ London School of Economics, United Kingdom \\ ${ }^{\mathrm{i}}$ Systemic Risk Centre, United Kingdom
}

\section{A R T I C L E I N F O}

\section{Article history:}

Received 15 September 2020

Revised 11 November 2020

Accepted 11 November 2020

Available online 21 November 2020

\section{JEL codes:}

D83

F50

I19

Keywords:

Epidemics

Trust

Scientists

Impressionable years

\begin{abstract}
A B S T R A C T
It is sometimes said that an effect of the COVID-19 pandemic will be heightened appreciation of the importance of scientific research and expertise. We test this hypothesis by examining how exposure to previous epidemics affected trust in science and scientists. Building on the "impressionable years hypothesis" that attitudes are durably formed during the ages $18-25$, we focus on individuals exposed to epidemics in their country of residence at this particular stage of the life course. Combining data from a 2018 Wellcome Trust survey of more than 75,000 individuals in 138 countries with data on global epidemics since 1970, we show that such exposure has no impact on views of science as an endeavor but that it significantly reduces trust in scientists and in the benefits of their work. We also illustrate that the decline in trust is driven by the individuals with little previous training in science subjects. Finally, our evidence suggests that epidemic-induced distrust translates into lower compliance with healthrelated policies in the form of negative views towards vaccines and lower rates of child vaccination.
\end{abstract}

(c) 2020 Elsevier B.V. All rights reserved.
"More shutdowns are avoidable, but the public needs to trust science."

(Anthony Stephen Fauci, Director of the U.S. National Institute of Allergy and Infectious Diseases' remarks at a virtual symposium hosted by Harvard University on 5 August 2020)

\footnotetext{
The order of author names is randomized via AEA Randomization Tool (code: tOjmA7DVzybq). All authors contributed equally to this manuscript. We thank Nicolás Ajzenman, Chris Anderson (discussant), Belinda Archibong, Sascha Becker, Damien Bol, Ralph De Haas, Anna Getmansky (discussant), Luigi Guiso, Bruce Hardy, Beata Javorcik, André Sapir, Konstantin Sonin, Dan Treisman, and webinar participants at the Bank of Finland, Comparative Economics Webinar series, EBRD, LSE and University of Sussex for helpful comments. We are also grateful to Kimiya Akhyani for providing very useful research assistance. Views presented are those of the authors and not necessarily those of the EBRD. All interpretations, errors, and omissions are our own.

* Corresponding author.

E-mail address: aksoyc@ebrd.com (C.G. Aksoy).
}

\section{Introduction}

The Covid-19 pandemic has highlighted disagreements among scientists, leading to criticism from politicians and the public. ${ }^{1}$ It has renewed long-standing concerns that lay perceptions of scientific disputes diminish the regard in which scientific findings are held and further "misunderstanding of how science operates and/ or...[lead] people to ignore scientific advice" (Dieckmann and Johnson, 2019). It has put on display leaders' "longstanding practice of undermining scientific expertise for political purposes" (Friedman and Plumer, 2020) and of engaging in "denigration of scientific expertise and harassment of scientists" (Scientists for ScienceBased Policy, 2020).

\footnotetext{
${ }^{1}$ See, for example, the Conversation article from April 8, 2020: https://theconversation.com/coronavirus-why-experts-disagree-so-strongly-over-how-to-tackle-thedisease-135825.
} 
One can distinguish several questions under this heading. First, are assessments of science as an endeavor and scientists as experts affected positively or negatively by the circumstances of a pandemic? Second, will changes in attitudes and opinions adhere mainly to the scientific endeavor or individual scientists? Will any reassessment of the importance of science apply to both the undertaking and those engaging in it, or will the public continue to trust science as a potential source of a vaccine, for example, while criticizing individual scientists who warn that the time needed to develop that vaccine will be lengthy?

We investigate in this paper how exposure to past epidemics affected trust in science and scientists. We use data from the 2018 Wellcome Global Monitor (WGM), which includes responses to questions about trust in science and scientists from over 75,000 individuals in 138 countries. We link these individual responses to the incidence of epidemics since 1970 as tabulated in the EM-DAT International Disasters Database. Building on work suggesting that individual attitudes and behavior are durably molded in what psychologists refer to as the "impressionable" late-adolescent and early-adult years, we show that impressionable-year epidemic exposure does not influence respondents' long-term views of the value of science as an endeavor or of its role in containing the spread of diseases. However, such exposure is negatively associated with trust in scientists and, specifically, with views of their integrity and trustworthiness. Specifically, an individual with the highest exposure to an epidemic (relative to zero exposure) is 11 percentage points less likely to have trust in the scientist (the respective average of this variable in our sample is $76 \%$ ).

Our data and setting allow us to extend and complement existing studies. We can examine trust in science and trust in scientists as separate outcomes. Using the cross-cohort variation generated by past epidemics, our analysis offers the broadest cross-national evidence to date on the relationship between exposure to epidemics and scientific trust. Whereas previous papers have looked at individual countries, our data cover 138 countries. This inspires greater confidence in the generality of the findings.

The negative relationship between past epidemic exposure during one's impressionable years and current trust in scientists is robust to controlling for a battery of political and economic shocks that may have coincided with an individual's impressionable years. We utilize the methodology developed by Oster (2019) to show that our results are unlikely to be driven by omitted variables. In addition, there is no such association in the case of trust in public health professionals (doctors, nurses, traditional healers, and others helping to manage the public-health consequences of an epidemic). And in line with the impressionable year hypothesis, this relationship is specific to the epidemic exposure between the ages of 18 and 25 .

Public distrust in science and scientists during and following an epidemic can be a product both of individuals' backgrounds and of miscommunication by the scientific community. Such miscommunication, including conflicting statements by different experts, is more likely in crisis periods when the pressure to quickly produce and disseminate scientific findings is intense (IFPRI, 2020). Members of the public who are not familiar with the scientific process may interpret the conflicting views of scientists and criticism of some studies by the authors of others as signs of bias or dishonesty. This paper cannot analyze the first argument, due to lack of data on scientific communication during past epidemics. But we provide suggestive evidence for the second, showing that individuals with little scientific training drive the negative relationship between past epidemic exposure and trust in scientists.

Effective epidemic control depends on public compliance with government mandates based on scientific advice. For example, trust in scientists recommending policies such as mask wearing, social distancing, lockdowns and mass vaccination will be associated with greater compliance with those recommendations. We directly investigate this channel, establishing that epidemic-induced distrust in scientists is associated with lower compliance with health-related advice. In particular, we show that past epidemic exposure negatively shapes respondents' long-term attitudes towards vaccination and reduces the likelihood that their children are vaccinated against childhood diseases.

Our paper contributes to several strands of literature. First, there are a number of studies of the impact of epidemics on trust-related outcomes, which reach conflicting results. Aassve et al. (2020) find that the Spanish Flu had permanent negative consequences for individuals' social trust. Bol et al. (2020), on the other hand, survey citizens of 15 European countries and find that COVID-19-related lockdowns were associated with a $2 \%$ increase in trust in government in the short term. Fluckiger et al. (2019), focusing on Ebola in West Africa, provide evidence that exposure to the epidemic enhanced trust in government, especially where governments responded robustly. In contrast, Aksoy et al. (2020) find a negative impact of past exposure to epidemics on confidence in government.

In addition, we know of one paper that has explored changes in trust in science following the outbreak of COVID-19. Agley (2020) shows that the overall level of trust in science remained unchanged between December 2019 and March 2020 in the United States, although conservatives reported slight increases and liberals reported slight decreases. ${ }^{2}$

Second, our paper is related to the literature on the trust in science and expert advice. Gauchat (2012) investigates public trust in science in the United States and documents differences by social class, ethnicity, gender, church attendance, and region. Sapienza and Zingales (2013) examine whether information about the consensus views of economists affects the views of average citizens, finding that knowledge of expert views sometimes moves public opinion in the opposite direction.

Third, there is the literature on scientific communication, which shows that different findings across studies may be seen by the public as discrediting the investigators, depending on how disagreements are presented (Scheufele, 2013; Van der Bles et al., 2020). These analyses point to the importance of scientists cultivating an aura of trustworthiness, in addition to asserting expertise (Fiske and Dupree, 2014). Related to this is the literature concerned with science and public opinion (Drummond and Fischhoff, 2017), in which it is argued that scientific knowledge may be invoked or dismissed insofar as it supports or challenges non-scientific (economic or political) concerns.

Fourth, there is the literature on the impressionable years. A seminal study pointing to the importance of this stage of the lifecycle is the survey of women attending Bennington College between 1935 and 1939 (Newcomb, 1943; Newcomb et al., 1967), among whom beliefs and values formed then remained stable for long periods. An early statement of the resulting hypothesis is Dawson and Prewitt (1969), Krosnick and Alwin (1989), among others, then pinpoint the impressionable years as running from ages 18 to 25 .

When rationalizing the importance of the impressionable years, some scholars draw on Mannheim's concept of the "fresh encounter," suggesting that views are durably formed when late adolescents first encounter new ideas or events. Others invoke Erikson (1968) to suggest that individuals at this age are open to new

\footnotetext{
${ }^{2}$ However, this study considers only the short-term impact of a single epidemic. In contrast, we consider a larger class of epidemics and test for persistent effects of experiencing epidemics during a critical juncture in individuals' life cycle, namely 'impressionable years'.
} 
influences because they are at the stage of life when they are forming a sense of self and identity. Still others suggest that attitudes are pliable at this stage of the lifecycle because views have not yet been hardened by confirmatory information (Converse, 1976). Spear (2000) links the the impressionable years to work in neurology, suggesting that these neurochemical and anatomical changes between the adolescent and adult brain are associated with durable attitude formation. Niemi and Sobieszek (1977, p.221 et seq) suggest that only in the late adolescent years have young people developed "the cognitive capacity to deal with political ideas" and that the same can be said to some extent of individuals in their university years (p.222).

In terms of applications, Giuliano and Spilimbergo (2013) establish that experiencing a recession between the ages of 18 and 25 has a significant impact on political preferences and beliefs about the economy. Using survey data from Chile, Etchegaray et al. (2018) show that individuals in their impressionable years in periods of political repression have a greater tendency to withhold their opinions, compared to those who grew up in less repressive times. Farzanegan and Gholipour (2019) find that Iranians experiencing the Iran-Iraq War in their impressionable years are more likely to prioritize a strong defense.

Finally, the present paper is related to Aksoy et al. (2020), where we find a negative impact of past epidemic exposure in confidence in the current political leader and in the integrity of the elections through which that leader is selected. But whereas, in that paper, we were able to investigate trust in the leader only in one setting (that of national government), here we observe views of the trustworthiness of scientists in two different settings: universities and private companies. In addition, we are able to link the changes in trust in the responsible authorities with compliance with their advice; we show that epidemic exposure that erodes trust in scientists is also associated with a reduced willingness to vaccinate one's children, both within the same group of individuals included in WGM survey.

The remainder of the paper is organized as follows. Section 2 describes our data. Section Section 3 outlines our empirical design and identification strategy. Section 4 presents the baseline results, after which Section 5 concludes.

\section{Data}

Our principal data sources are 2018 Wellcome Global Monitor (WGM) and the EM-DAT International Disasters Database. WGM is a nationally representative survey fielded in 2018. Our final merged sample includes 138 countries. WGM is the first global survey of how people think and feel about key health and science challenges, including attitudes towards vaccines; trust in doctors, nurses and scientists; trust in medical advice from the government; whether people believe in the benefits of science.

The main outcome variables of interest come from questions asked of all WGM respondents regarding their trust in science and scientists:

(i) "in general, would you say that you trust science a lot, some, not much, or not at all?";

(ii) "how much do you trust scientists working in colleges/universities in this country to do each of the following?"

a. to do their work with the intention of benefiting the public

b. to be open and honest about who is paying for their work

(iii) "thinking about companies - for example, those who make medicines or agricultural supplies - how much do you trust scientists working for companies in this country to do each of the following?" c. to do their work with the intention of benefiting the public

d. to be open and honest about who is paying for their work

(iv) "in general, how much do you trust scientists to find out accurate information about the world? A lot, some, not much, or not at all?"

Responses were coded on a 4-point Likert scale, ranging from "A lot" (1) to "Not at all" (4). We code "A lot" and "Some" as 1 and zero otherwise in order to estimate a Linear Probability Model (LPM). ${ }^{3}$

WGM also provides information on respondents' demographic characteristics (age, gender, educational attainment, marital status, religion, and urban/rural residence), labor market outcomes, and within-country income quintiles. Controlling for employment status and income allows us to measure the impact of past epidemics on trust in science and scientists beyond any direct effect of epidemics on material well-being.

We also examine responses to three parallel questions as placebo outcomes, namely whether the respondents have trust in doctors and nurses; hospitals and health clinics; traditional healers. This helps us to determine whether what we are capturing is the impact of epidemic exposure on views of scientists specifically, as distinct from any impact on views of healthcare-related institutions and professionals.

Data on the worldwide epidemic occurrence and effects are drawn from the EM-DAT International Disasters Database from 1970 to the present. ${ }^{4}$ These data are compiled from UN agencies, non-governmental organizations, insurance companies, research institutes, press agencies, and other sources. It includes all epidemics (viral, bacterial, parasitic, fungal, and prion) meeting one or more of the following criteria: (i) 10 or more people dead; (ii) 100 or more people affected; (iii) declaration of a state of emergency; (iv) a call for international assistance.

Our dataset includes 47 different types of epidemics and pandemics since 1970. This includes large outbreaks of Cholera, Ebola, and H1N1 and also more limited epidemics. Averaged across available years, H1N1, Ebola, Dysentery, Measles, Meningitis, Cholera, Yellow Fever, Diarrhoeal Syndromes, Marburg Virus, and Pneumonia were the top 10 diseases causing epidemic mortality worldwide.

Many of these epidemics and pandemics affected multiple countries. 138 countries experienced at least one epidemic since 1970. This includes 51 countries in Africa, 40 in Asia, 22 in the Americas, 19 in Europe, and 5 in Oceania. The most epidemicprone countries in the dataset are Niger (25), Nigeria (25), Congo (22), Cameroon (21), Mozambique (20), Sudan (20), Uganda (20) and India (19). Advanced countries in our sample all experienced 5 or fewer epidemics. ${ }^{5}$

Each epidemic is identified with the country where it took place. When an epidemic affects several countries, several separate entries are made to the database for each. EM-DAT provides information on the start and end date of the epidemic, the number of deaths, and the number of individuals affected. The number of individuals affected refers to the total number requiring immediate assistance (assistance with basic survival needs such as food, water, shelter, sanitation, and immediate medical treatment) during the period of emergency. We aggregate the epidemic related

\footnotetext{
${ }^{3}$ In Appendix Tables A16 and A17, we also show that our results are robust to using ordered logit and multinomial logit models.

${ }^{4}$ EM-DAT was established in 1973 as a non-profit within the School of Public Health of the Catholic University of Louvain; it subsequently became a collaborating center of the World Health Organization. It also gathers historical information on epidemics that took place before it was founded; however, those data are patchy and biased towards well-recorded epidemics. Hence we only focus on epidemic cases that EM-DAT "live" collected after it was founded in early 1970s.

5 We provide the full country-year-epidemic list in Appendix Table A18.
} 
information in this database at the county-year level and merge it with WGM. Fig. 1 provides a visual summary.

We also use country level information from the Cross-National Time-Series (CNTS) dataset to control for individuals' past experiences and get information on past media consumption (TV units per capita and radio units per capita). Country level past economic experience variables come from the World Bank. The data on political regime comes from the Polity. ${ }^{6}$

\section{Empirical Model}

To assess the effect of past exposure to an epidemic on an individual's trust in science and scientists, we estimate the following OLS specification:

$$
\begin{aligned}
\mathrm{Y}_{\mathrm{i}, \mathrm{c}, \mathrm{a}}= & \beta_{0}+\beta_{1} \mathrm{X}_{\mathrm{i}}+\beta_{2} \text { Exposure to epidemic }(18-25)_{\text {ica }} \\
& +\beta_{3} \mathrm{C}_{\mathrm{c}}+\beta_{4} \mathrm{~A}_{\mathrm{a}}+\beta_{5} \mathrm{C}_{\mathrm{c}} * \text { Age }+\varepsilon_{\text {ica }}
\end{aligned}
$$

where $Y_{\text {ica }}$ is a dummy variable indicating whether or not the respondent $i$ with age $a$ in country $c$ has trust in science or scientists. To operationalize Exposure to epidemic (18-25), we calculate for each individual the number of people affected by an epidemic as a share of the population, averaged over the 8 years when the individual was in his or her impressionable years (18-25 years old). ${ }^{7}$ The coefficient of interest is $\beta_{2}$, which captures the impact of past exposure to an epidemic on the trust in science or scientists.

We specify the $X_{i}$ vector of individual characteristics to include: indicator variables for living in an urban area and for having a child (any child under 15), and dummy variables for gender (male), employment status (full-time employed by an employer, fulltime self-employed, part-time employed with intention for fulltime, part-time employed with no intention for full-time, unemployed, out of workforce), religion (religious vs. non-religious), educational attainment (tertiary education, secondary education), and within-country income quintiles.

To account for unobservable characteristics, we include fixed effects separately at the levels of country $\left(C_{c}\right)$ and age cohort $\left(A_{a}\right)$ (that is, cohort fixed effects). The country dummies control for all variation in the outcome variable due to factors that vary crossnationally. The cohort fixed effects control for the variation in the outcome variable caused by factors that are heterogeneous across (but homogenous within) birth cohorts. ${ }^{8}$ By controlling for these and other variables separately, we can be confident that their effects are not being picked up by impressionable-year epidemic exposure. In addition to saturating our specification with country and cohort fixed-effects, we include country-specific age trends $\left(C c^{*} A g e\right) .{ }^{9}$ These address the possibility that, even though we control for overall cohort and age-related factors, the interaction of age and attitudes may differ across countries. In further robustness checks, we also include country*income quintile, country*employment status and country*education fixed effects.

\footnotetext{
${ }^{6}$ Past experience variables include GDP growth, GDP per capita, the inflation rate, the political regime (the Polity2 score), assassinations, general strikes, terrorism/ guerrilla warfare, purges, riots, revolutions, and anti-government demonstrations, government crises, physicians per capita and university enrollment per capita.

7 In Appendix Tables A5 and A6, we show that our results are robust to using "population unadjusted epidemic exposure" variable. Additionally, the results are qualitatively same once we employ a time-invariant measure for population (see Appendix Tables A7 and A8).

8 Since WGM contains a cross-section of countries at a single point in time (as of 2018), our cohort fixed effects fully coincide with the age dummies that one would ideally like to include in Eq. (1). Thus, even though we cannot separately estimate the age-fixed effects due to such perfect collinearity, our setting indirectly controls for all age-related heterogeneity by including these cohort fixed-effects.

${ }^{9}$ Our results remain virtually unchanged when we include country-quadratic age trends. These results are available upon request.
}

We cluster standard errors by country and use sampling weights provided by the WGM to make the data representative at the country level.

\subsection{Identification}

One can imagine several potential threats to this strategy. First, age-specific factors may matter if different generations were exposed to epidemics with different probabilities; given advances in science and improvements in national healthcare systems, one might anticipate that epidemics are less likely to be experienced by younger generations. We address these concerns by including a full set of cohort fixed effects determined by an individual's year of birth.

Second, generational trends in science attitudes could also be heterogeneous across countries. Some national cultures may be more flexible and open to change in individual values and beliefs, leading to larger differences across generations. We therefore include country-specific age trends in our models.

Third, although we fully saturate our specifications with fixed effects, there could still be other past exposures that are correlated with epidemics and matter for individuals' views regarding science and scientists. To capture these additional exposures, we control for various aspects of the political and socio-economic environment (GDP growth, GDP per capita, inflation rate, political regime -the Polity2 score-, assassinations, general strikes, terrorism/guerrilla warfare, purges, riots, revolutions, antigovernment demonstrations, government crises, physicians per capita and university enrollment per capita) in the country in question during the individual's impressionable years. Thus, we confirm that including these controls for other past exposures and conditions has minimal impact on the stability of our coefficients of interest.

Lastly, we control for contemporaneous individual characteristics and economic circumstances as captured by the WGM. These contemporaneous controls minimize the possibility that the impact of a past epidemic is transferred to current outcomes via one of these variables. These variables might also be considered as 'bad controls' (Angrist and Pischke, 2009). As we reported in the Appendix A, removing them does not substantively change any of our findings.

\section{Results}

\subsection{Main results}

Table 1 reports the results for all dependent variables in WGM dataset related to respondents' views of scientists: whether the respondent has trust in scientists in their country; trusts that scientists working for private companies in their country aim to benefit the public; trusts that scientists working for private companies in their country are honest about who is paying for their work; trusts that scientists working for universities in their country aim to benefit the public; trusts that scientists working for universities in their country are honest about who is paying for their work; and trusts that scientists can find out accurate information about the world.

Models/Columns 1-3, estimated on the full sample of respondents, progressively increase the tightness of identification by adding controls at each step. Models/Columns 4-6 then add fixed effects, where individuals in the treatment and control groups are only compared within the same country and income level (Model 4), the same country and employment status (Model 5), and the same country and educational attainment (Model 6). 


\section{Panel A}

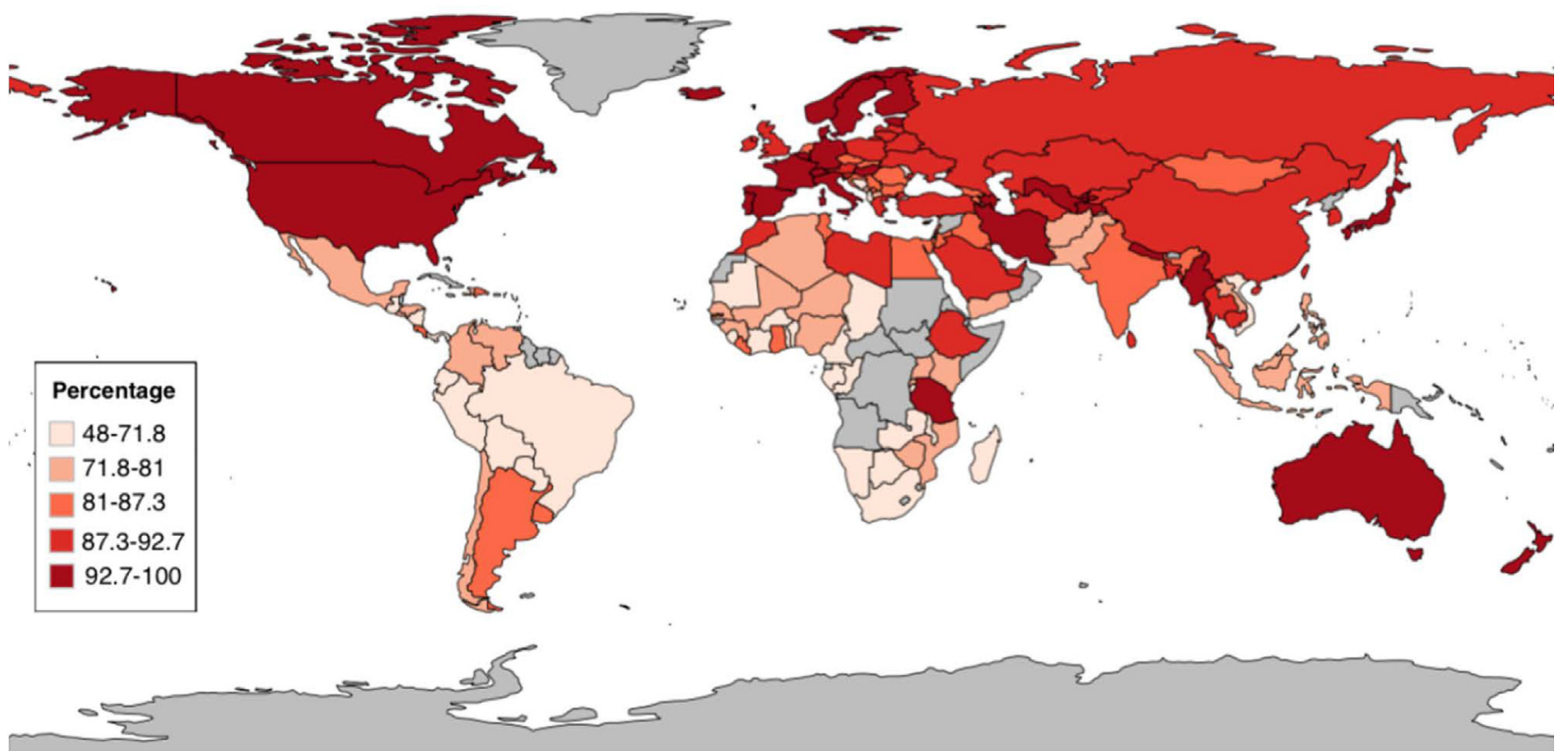

Panel B

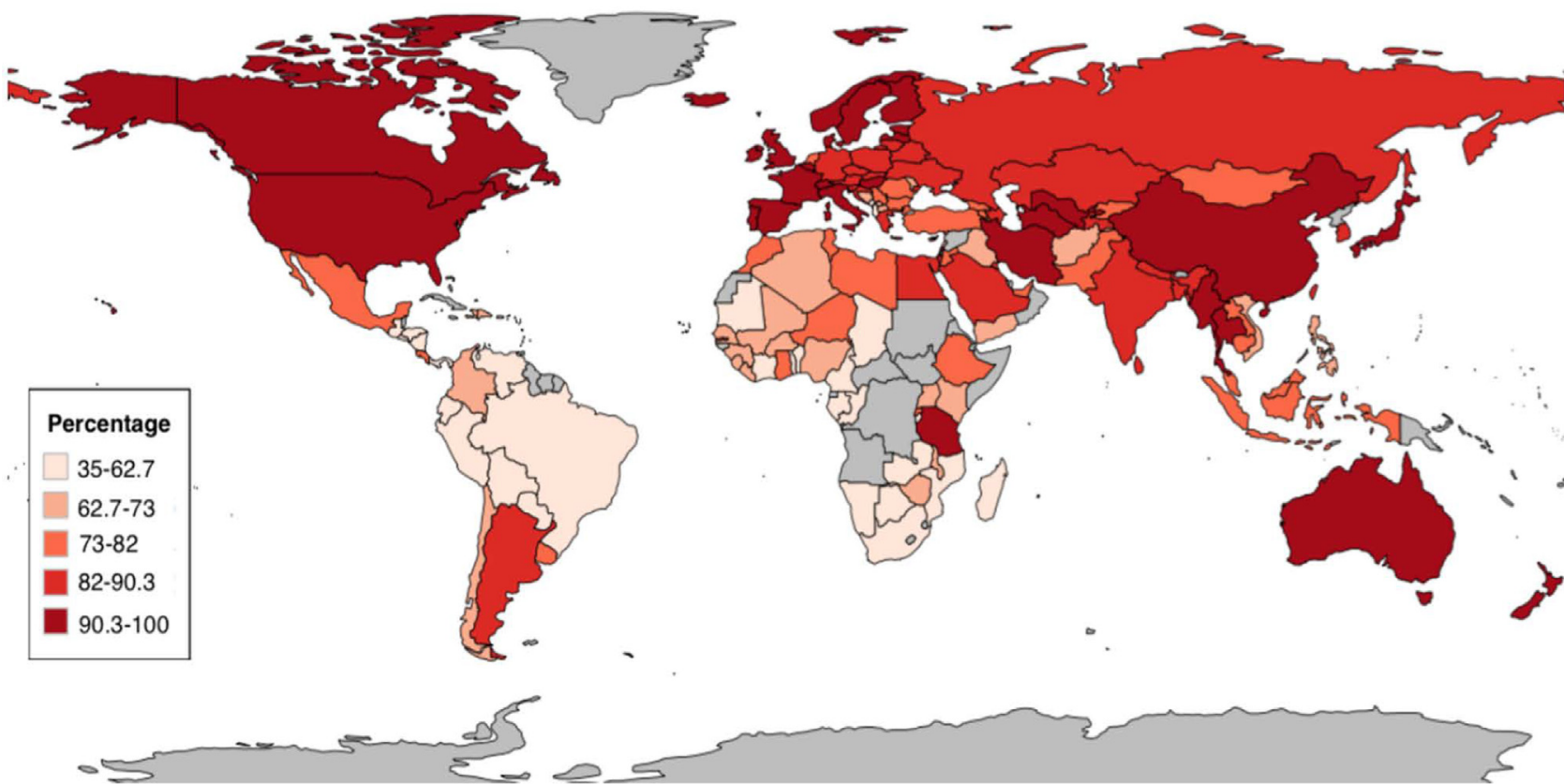

Notes: Panel A illustrates share of respondents who trust science a lot or some. Panel B illustrates share of respondents who trust scientists a lot or some. Countries are grouped in quintiles. Source: Wellcome Global Monitor, 2018.

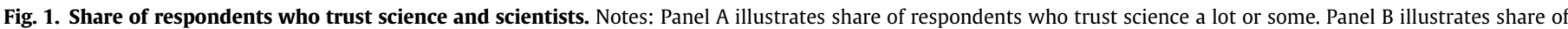
respondents who trust scientists a lot or some. Countries are grouped in quintiles. Source: Wellcome Global Monitor, 2018.

The coefficients on impressionable-year epidemic exposure are negative and significant at conventional levels in 29 of 36 cases. $^{10}$ The estimates in Column 3 of Table 1, for example, show that an individual with the highest exposure to epidemics $(0.032$, that is, the highest number of people affected by an epidemic as a share of the population averaged during an individual's formative years)

\footnotetext{
${ }^{10}$ Later in a robustness check, we confirm the relevance of our treatment variable across multiple hypotheses.
}

relative to individuals with no exposure is on average 11 percentage points $(-3.454 * 0.032)$ less likely to trust in scientists in their country (the respective average of this variable in our sample is $76 \%$ ). ${ }^{11}$

\footnotetext{
${ }^{11}$ We use the highest number in terms of past epidemics exposure as this varible is highly skewed with more than half of the respondents having no experience at all; and thus, it would not be appropriate to benchmark the effect size with mean or median.
} 
Table 1

The Impact of Exposure to Epidemic (18-25) on Trust in Scientists.

\begin{tabular}{|c|c|c|c|c|c|c|}
\hline & $(1)$ & $(2)$ & (3) & $(4)$ & $(5)$ & (6) \\
\hline \multicolumn{7}{|l|}{ Outcome $\rightarrow$ Trust in scientists } \\
\hline Exposure to Epidemic (18-25) & $\begin{array}{l}-2.937^{*} \\
(1.600)\end{array}$ & $\begin{array}{l}-2.821^{*} \\
(1.645)\end{array}$ & $\begin{array}{l}-3.454^{* *} \\
(1.330)\end{array}$ & $\begin{array}{l}-3.408^{* *} \\
(1.422)\end{array}$ & $\begin{array}{l}-3.162^{* *} \\
(1.468)\end{array}$ & $\begin{array}{l}-3.525^{* *} \\
(1.421)\end{array}$ \\
\hline Observations & 83,014 & 82,854 & 82,854 & 82,854 & 82,854 & 82,854 \\
\hline $\begin{array}{l}\text { Outcome } \rightarrow \text { Scientists working } \\
\text { Exposure to Epidemic (18-25) }\end{array}$ & $\begin{array}{c}\text { companies } \\
-1.552^{* * *} \\
(0.354)\end{array}$ & $\begin{array}{l}\text { public } \\
-1.559^{* * *} \\
(0.349)\end{array}$ & $\begin{array}{l}-1.283^{* * *} \\
(0.338)\end{array}$ & $\begin{array}{l}-1.289^{* * *} \\
(0.389)\end{array}$ & $\begin{array}{l}-1.141^{* *} \\
(0.447)\end{array}$ & $\begin{array}{l}-1.346^{* * *} \\
(0.375)\end{array}$ \\
\hline Observations & 81,554 & 81,406 & & & & \\
\hline $\begin{array}{l}\text { Outcome } \rightarrow \text { Scientists working } \\
\text { Exposure to Epidemic (18-25) }\end{array}$ & $\begin{array}{c}\text { companies } \\
-2.105^{* * *} \\
(0.597) \\
76,856\end{array}$ & $\begin{array}{l}-2.106^{* * *} \\
(0.611) \\
76,723\end{array}$ & $\begin{array}{l}-1.731^{* * *} \\
(0.642) \\
76.723\end{array}$ & $\begin{array}{l}-1.915^{* * *} \\
(0.661) \\
76.723\end{array}$ & $\begin{array}{l}-1.611^{* * *} \\
(0.466) \\
76.723\end{array}$ & $\begin{array}{l}-1.779^{* * *} \\
(0.620) \\
76.723\end{array}$ \\
\hline \multicolumn{7}{|c|}{ Outcome $\rightarrow$ Scientists working for universities benefit the public } \\
\hline Exposure to Epidemic (18-25) & $\begin{array}{l}0.150 \\
(0.727)\end{array}$ & $\begin{array}{l}0.226 \\
(0.752)\end{array}$ & $\begin{array}{l}-0.616 \\
(0.478)\end{array}$ & $\begin{array}{l}-0.836^{*} \\
(0.459)\end{array}$ & $\begin{array}{l}-0.572 \\
(0.500)\end{array}$ & $\begin{array}{l}-0.808^{*} \\
(0.448)\end{array}$ \\
\hline Observations & 81,307 & 81,147 & 81,147 & 81,147 & 81,147 & 81,147 \\
\hline \multicolumn{7}{|c|}{ Outcome $\rightarrow$ Scientists working for universities are honest } \\
\hline Exposure to Epidemic (18-25) & $\begin{array}{l}-3.042^{* * *} \\
(0.375)\end{array}$ & $\begin{array}{l}-2.980^{* * *} \\
(0.413)\end{array}$ & $\begin{array}{l}-3.330^{* * *} \\
(0.446)\end{array}$ & $\begin{array}{l}-3.442^{* * *} \\
(0.471)\end{array}$ & $\begin{array}{l}-3.259^{* * *} \\
(0.356)\end{array}$ & $\begin{array}{l}-3.337^{* * *} \\
(0.531)\end{array}$ \\
\hline Observations & 76,123 & 75,992 & 75,992 & 75,992 & 75,992 & 75,992 \\
\hline \multicolumn{7}{|c|}{ Outcome $\rightarrow$ Scientists to find out accurate information } \\
\hline Exposure to Epidemic (18-25) & $\begin{array}{l}-1.352 \\
(0.988)\end{array}$ & $\begin{array}{l}-1.188 \\
(1.137)\end{array}$ & $\begin{array}{l}-1.438^{* *} \\
(0.664)\end{array}$ & $\begin{array}{l}-1.873^{* * *} \\
(0.644)\end{array}$ & $\begin{array}{l}-1.185 \\
(0.752)\end{array}$ & $\begin{array}{l}-1.704^{* *} \\
(0.717)\end{array}$ \\
\hline Observations & 84,104 & 83,939 & 83,939 & 83,939 & 83,939 & 83,939 \\
\hline Country fixed effects & Yes & Yes & Yes & No & No & No \\
\hline Cohort fixed effects & Yes & Yes & Yes & Yes & Yes & Yes \\
\hline Demographic characteristics & No & Yes & Yes & Yes & Yes & Yes \\
\hline Income quintile fixed effects & No & Yes & Yes & No & Yes & Yes \\
\hline Labour market controls & No & Yes & Yes & Yes & No & Yes \\
\hline Country-specific age trends & No & No & Yes & Yes & Yes & Yes \\
\hline Country * Income fixed effects & No & No & No & Yes & No & No \\
\hline Country ${ }^{*}$ Empl. fixed effects & No & No & No & No & Yes & No \\
\hline Country * Educ. fixed effects & No & No & No & No & No & Yes \\
\hline
\end{tabular}

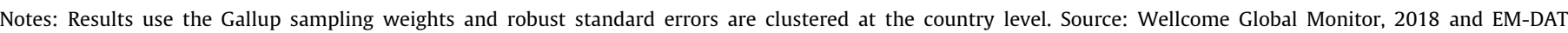
International Disaster Database, $1970-2017$. *Significant at $10 \% ;{ }^{* *}$ Significant at $5 \% ;{ }^{* * *}$ Significant at $1 \%$.

Table 2 reports estimates of the same models for six additional dependent variables. The first three are related to the societal impact of science: whether the respondent has trust in science; thinks that science will help improve life for the next generation; and thinks that studying disease is a part of science. The next three are placebo tests that address the possibility that what we are picking up is not the impact on the perceived trustworthiness and public-spiritedness of scientists engaged in health-related research specifically but the impact on perceptions of individuals engaged in tasks related to healthcare and health outcomes generally. In contrast to Table 1 , Table 2 shows that formative-year epidemic exposure has a positive, small and statistically insignificant effect on almost all of these outcome variables. The effect we find is not a general decline in trust in science, but only in scientists. It is not a general decline in trust in everyone engaged in health care, only in scientists researching health care related issues. ${ }^{12}$

\footnotetext{
12 One could be concerned that our preferred specification (Model 3) in Tables 1 and 2 contains country-specific age trends, which could be collinear with our treatment variable (Exposure to Epidemic (18-25)). On the one hand, there is little to suspect that our treatment variable would vary in a certain direction in line with the age of the respondents in a country since we focus on the same past experience window (ages 18-25) irrespective of what the age of the respondent is at the time of the survey. On the other hand, it is reassuring that our results change very little when we drop these age trends in our estimations (see Models 1 and 2 in Tables 1 and 2).
}

\subsection{Heterogeneity by the level of science education}

Given that previous work points to science education as shaping views of science and scientists, we also estimate our main specification for two subsamples: respondents who learned about science at most at the primary school level, versus respondents who learned about science at least at the secondary school level. The results, in Table 3, reveal substantial differences. They suggest that our results are driven by the sample of individuals with little or no science education. Additional analysis (not presented here but available upon request) suggests that these results cannot be explained by the possible interruption in education due to exposure to an epidemic. ${ }^{13}$

\footnotetext{
13 We also check the role of media consumption in shaping attitudes towards scientists at the time of the epidemics. To do so, we use the country-level data from CNTS, which reports TV units per capita and Radio units per capita for a large number of countries. In particular, we calculate the average values for each dimension during the impressionable years of each individual. We then create interaction terms, Exposure to Epidemic (18-25)*TV Per Capita (18-25) and Exposure to Epidemic (18$25)^{*}$ Radio Per Capita (18-25), and include them (alongside standalone variables) in our baseline model as reported in Appendix Table A15. The results show that none of the interactions are statistically significant, suggesting that media consumption is not likely to be the main transmission channel in our setting.
} 
Table 2

The Impact of Exposure to Epidemic (18-25) on Trust in Science and Placebo Outcomes.

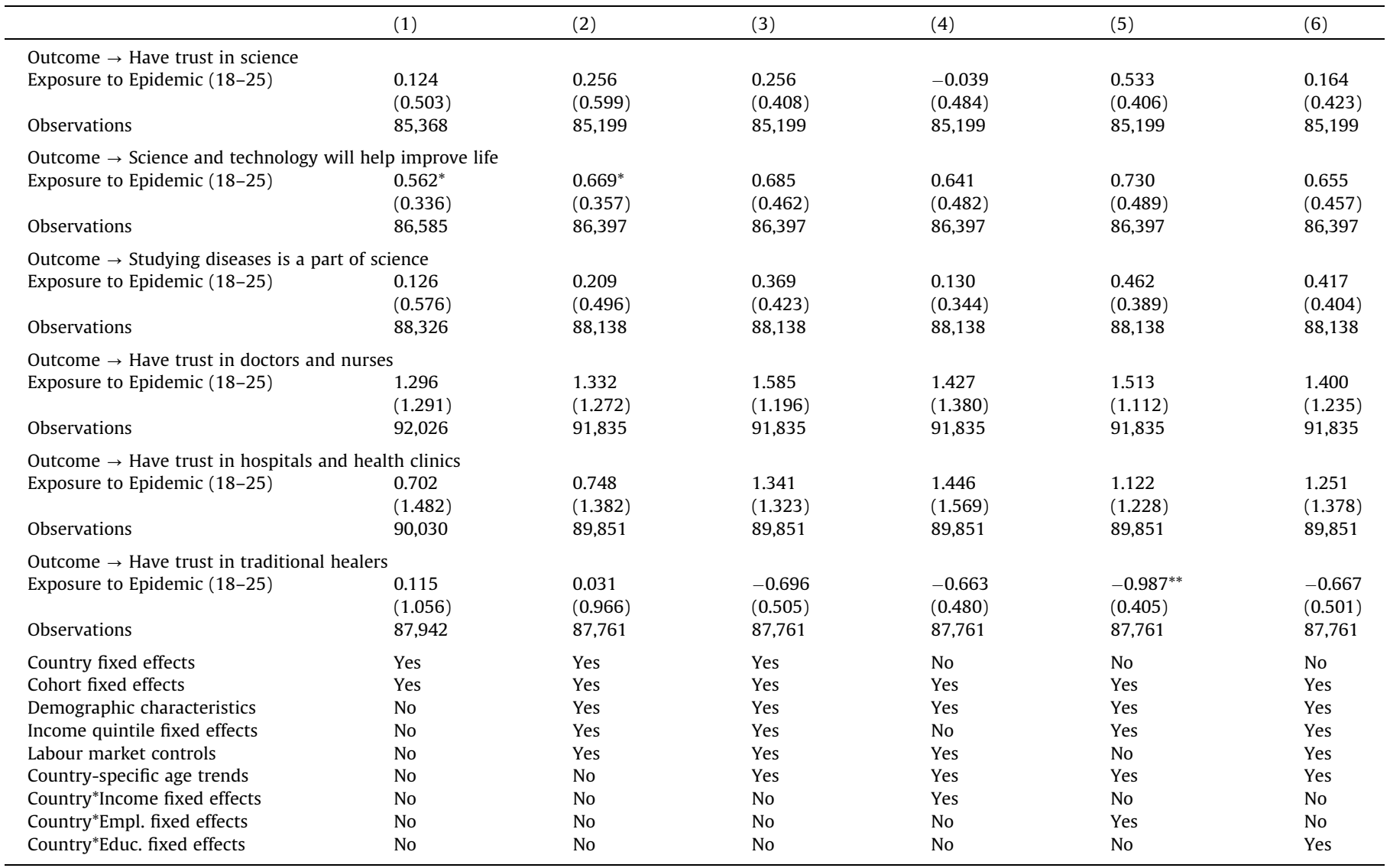

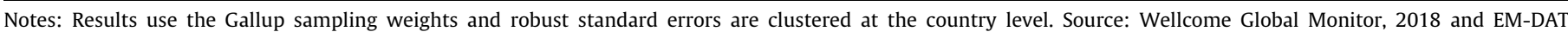
International Disaster Database, $1970-2017$. ${ }^{*}$ Significant at $10 \% ;{ }^{* *}$ Significant at $5 \% ;{ }^{* * *}$ Significant at $1 \%$.

\subsection{Are the results driven by other past experience?}

In a robustness check, we control for other political and socioeconomic experiences, the timing of which corresponds to the same impressionable years (ages 18-25). For each individual we add GDP growth, GDP per capita, inflation rate, political regime Polity2 score-, assassinations, general strikes, terrorism/guerrilla warfare, purges, riots, revolutions, anti-government demonstrations, government crises, physicians per capita and university enrollment per capita at the time of the survey response. ${ }^{14}$ If such shocks coincide with epidemics, omitting them may exaggerate the estimated effect of the latter.

Appendix Table A1 reports the results across the same six outcome variables related to trust in scientists and shows that the impact of epidemic exposure on trust in scientists -if anythingbecome larger, not smaller, once we control for these other past political and economic shocks. This is consistent with the idea that what we are capturing is specific to epidemics and not related to other coincident shocks.

\subsection{Changes in actual behaviour}

We ask whether the loss of trust in scientists has implications for actual behavior. We focus on changes in vaccinerelated attitudes and on the tendency for individuals to vacci-

\footnotetext{
${ }^{14}$ In particular, we calculate the average values for each one of these dimensions during the impressionable years of each individual. Including these past experiences as controls naturally makes for smaller samples, since the Cross-National Time-Series Data Archive covers only some of the countries and years in our main sample.
}

nate their own children. Table 4 presents estimates analogous to Model 3 of Table 1, while simultaneously controlling for other past economic and political shocks. Individuals exposed to epidemics in their impressionable years are more likely to have negative attitudes towards vaccination and less likely to vaccinate their children. This suggests that the change in attitudes that we document have consequences for actual behavior.

\subsection{Robustness to omitted variable bias}

One might be concerned that our results are driven by other omitted factors that shape the individuals' trust. We therefore follow the method proposed by Oster (2019) to investigate the importance of unobservables. In Appendix Table A2, we first reproduce the baseline estimates for our main outcomes in the top row. The second row then presents estimation bounds where we define $\mathrm{R}_{\max }$ upper bound as 1.3 times the R-squared in specifications that control for observables. ${ }^{15}$ The bottom row presents Oster's delta, which indicates the degree of selection on unobservables relative to observables that would be needed to fully explain our results by omitted variable bias.

The results show very limited movement in the coefficients. High delta values also indicate that the unobservables have less

\footnotetext{
15 Estimation bounds on the treatment effect range between the coefficient from the main specification and the coefficient estimated under the assumption that observables are as important as unobservables for the level of $R_{\max }$. $R_{\max }$ specifies the maximum R-squared that can be achieved if all unobservables were included in the regression.
} 
Table 3

The Impact of Exposure to Epidemic (18-25) on Confidence in Scientists by the Level of Science Education.

\begin{tabular}{|c|c|c|c|c|c|c|}
\hline Outcome $\rightarrow$ & $\begin{array}{l}(1) \\
\text { Confidence } \\
\text { in scientists }\end{array}$ & $\begin{array}{l}\text { (2) } \\
\text { Scientists working for private } \\
\text { companies benefit the public }\end{array}$ & $\begin{array}{l}\text { (3) } \\
\text { Scientists working for } \\
\text { private companies are } \\
\text { honest }\end{array}$ & $\begin{array}{l}\text { (4) } \\
\text { Scientists working for } \\
\text { universities benefit the } \\
\text { public }\end{array}$ & $\begin{array}{l}\text { (5) } \\
\text { Scientists working for } \\
\text { universities are } \\
\text { honest }\end{array}$ & $\begin{array}{l}\text { (6) } \\
\text { Scientists to find out } \\
\text { accurate } \\
\text { information }\end{array}$ \\
\hline \multicolumn{7}{|c|}{ Sample $\rightarrow$ Respondents learned about science at most at primary school level } \\
\hline \multirow[t]{2}{*}{$\begin{array}{l}\text { Exposure to } \\
\text { Epidemic } \\
(18-25)\end{array}$} & $-4.521^{* * *}$ & $-4.140^{* * *}$ & $-2.443^{* *}$ & 0.186 & -0.891 & -0.253 \\
\hline & $(0.888)$ & $(1.162)$ & $(0.971)$ & $(1.323)$ & $(3.436)$ & $(0.488)$ \\
\hline Observations & 14,434 & 13,984 & 12,931 & 13,752 & 12,668 & 14,300 \\
\hline \multicolumn{7}{|c|}{ Sample $\rightarrow$ Respondents learned about science at least at secondary school level } \\
\hline \multirow{2}{*}{$\begin{array}{l}\text { Exposure to } \\
\text { Epidemic } \\
(18-25)\end{array}$} & 1.332 & $3.270^{* * *}$ & -1.545 & 1.529 & -0.441 & -1.315 \\
\hline & $(2.547)$ & $(0.831)$ & $(2.370)$ & $(1.780)$ & $(1.285)$ & $(1.037)$ \\
\hline Observations & 57,892 & 57,054 & 54,130 & 57,206 & 53,755 & 59,232 \\
\hline $\begin{array}{l}\text { Country fixed } \\
\text { effects }\end{array}$ & Yes & Yes & Yes & Yes & Yes & Yes \\
\hline $\begin{array}{l}\text { Cohort fixed } \\
\text { effects }\end{array}$ & Yes & Yes & Yes & Yes & Yes & Yes \\
\hline Demographic & & characteristics & Yes & Yes & Yes & Yes \\
\hline Yes & Yes & & & & & \\
\hline $\begin{array}{l}\text { Income } \\
\text { quintile } \\
\text { fixed } \\
\text { effects }\end{array}$ & Yes & Yes & Yes & Yes & Yes & Yes \\
\hline $\begin{array}{l}\text { Labour market } \\
\text { controls }\end{array}$ & Yes & Yes & Yes & Yes & Yes & Yes \\
\hline $\begin{array}{l}\text { Country- } \\
\text { specific age } \\
\text { trends }\end{array}$ & Yes & Yes & Yes & Yes & Yes & Yes \\
\hline
\end{tabular}

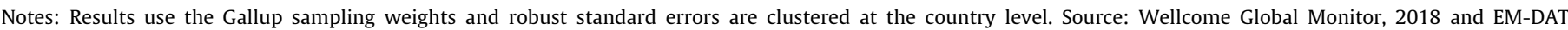
International Disaster Database, 1970-2017. *Significant at 10\%; ${ }^{* *}$ significant at 5\%; ${ }^{* * *}$ significant at $1 \%$.

Table 4

The Impact of Exposure to Epidemic on Attitudes towards Vaccines.

\begin{tabular}{|c|c|c|c|c|c|c|c|c|}
\hline Outcome $\rightarrow$ & $\begin{array}{l}(1) \\
\text { Children } \\
\text { received a } \\
\text { vaccine }\end{array}$ & $\begin{array}{l}(2) \\
\text { Children } \\
\text { received a } \\
\text { vaccine }\end{array}$ & $\begin{array}{l}\text { (3) } \\
\text { Vaccines are important } \\
\text { for children to have }\end{array}$ & $\begin{array}{l}\text { (4) } \\
\text { Vaccines are important } \\
\text { for children to have }\end{array}$ & $\begin{array}{l}(5) \\
\text { Vaccines } \\
\text { are safe }\end{array}$ & $\begin{array}{l}(6) \\
\text { Vaccines } \\
\text { are safe }\end{array}$ & $\begin{array}{l}(7) \\
\text { Vaccines are } \\
\text { effective }\end{array}$ & $\begin{array}{l}(8) \\
\text { Vaccines are } \\
\text { effective }\end{array}$ \\
\hline \multirow{2}{*}{$\begin{array}{l}\text { Exposure to } \\
\text { Epidemic (18- } \\
25)\end{array}$} & $-1.341^{* * *}$ & $-1.479^{* * *}$ & $-1.562^{* * *}$ & $-1.272^{* *}$ & $-4.694^{* * *}$ & $-4.461^{* * *}$ & $-2.446^{* * *}$ & $-1.959 * * *$ \\
\hline & $(0.311)$ & $(0.334)$ & $(0.538)$ & $(0.522)$ & $(0.490)$ & $(0.533)$ & $(0.602)$ & $(0.624)$ \\
\hline Observations & 25,774 & 25,774 & 30,955 & 30,955 & 30,330 & 30,330 & 30,383 & 30,383 \\
\hline $\begin{array}{l}\text { Country fixed } \\
\text { effects }\end{array}$ & Yes & Yes & Yes & Yes & Yes & Yes & Yes & Yes \\
\hline $\begin{array}{l}\text { Cohort fixed } \\
\text { effects }\end{array}$ & Yes & Yes & Yes & Yes & Yes & Yes & Yes & Yes \\
\hline $\begin{array}{l}\text { Demographic } \\
\text { characteristics }\end{array}$ & Yes & Yes & Yes & Yes & Yes & Yes & Yes & Yes \\
\hline $\begin{array}{l}\text { Income quintile } \\
\text { fixed effects }\end{array}$ & Yes & Yes & Yes & Yes & Yes & Yes & Yes & Yes \\
\hline $\begin{array}{l}\text { Labour market } \\
\text { controls }\end{array}$ & Yes & Yes & Yes & Yes & Yes & Yes & Yes & Yes \\
\hline $\begin{array}{l}\text { Country-specific } \\
\text { age trends }\end{array}$ & Yes & Yes & Yes & Yes & Yes & Yes & Yes & Yes \\
\hline $\begin{array}{l}\text { Past controls } \\
\qquad(18-25)\end{array}$ & No & Yes & No & Yes & No & Yes & No & Yes \\
\hline
\end{tabular}

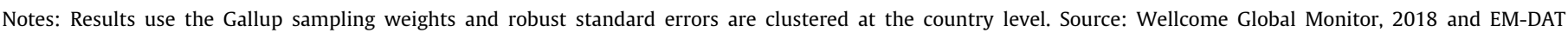
International Disaster Database, 1970-2017. ${ }^{*}$ significant at $10 \% ;{ }^{* *}$ significant at $5 \%$; ${ }^{* * *}$ significant at $1 \%$.

effect on our coefficient of interest than the observables. The value of Oster's delta ranges between 2 and 132 across models, which is reassuring, as it is unlikely that there are unobserved factors that are 2-132 times as important as all observables we include in our preferred specification.

\subsection{Are the results unique to impressionable years?}

The results in Appendix Table A3 suggest that the effect is insignificant when individuals are exposed to epidemics in any stage of life other than when they are between ages 18 and 25 . 
These results are consistent with the idea that there is something special about the late adolescent and early adult years that leaves a long-lasting legacy in beliefs and attitudes.

\subsection{Multiple hypothesis testing}

We also conducted multiple hypothesis testing by employing a randomization inference technique suggested by Young (2019). This helps us establish the robustness of our results for the null that our treatment does not have any effect across any of the outcome variables (i.e., treatment is irrelevant), taking into account the multiplicity of the hypothesis testing procedure. The method essentially builds on repeatedly randomizing the treatment variable in each estimation and comparing the pool of randomized estimates to the estimates derived via the true treatment variable. The results, presented in Appendix Table A4, show that our findings remain robust when evaluated via these joint tests of treatment significance.

\subsection{Robustness to alternative treatment definitions}

In our baseline results, we standardize our treatment variable by dividing the average number of epidemic-affected people with the average population size of the country during one's impressionable years. This standardization is crucial as one would expect that countries with larger populations would naturally have more people infected by an epidemic since viruses are socially transmitted and the eventual toll would depend on how many people live in a country.

Nevertheless, one might be concerned that a small population in a country may increase the intensity of the epidemic as well as the intensity of the epidemic affecting the population counts (through both mortality and immigration). We, therefore, checked the robustness of our results using population unadjusted treatment variable: simply the number of individuals affected by an epidemic averaged over the 8 years when the individual was aged 18-25. The results presented in Appendix Tables A5 and A6 show that our results are robust to this alternative definition.

In addition, in Appendix Tables A7 and A8, we show that our results remain qualitatively identical when we use the treatment variable adjused by a time-invariant population size (that is, using a population measure as of 1970).

\subsection{Heterogeneity by the country characteristics}

We consider the baseline specification (Column 3 of Table 1 ) for two subsamples: (i) countries with below and above median physicians per capita at the time of the epidemic; (ii) low-income countries vs. high-income countries. We report these results in Appendix Table A9, where each cell reports point estimates for a different outcome varible.

The negative impact of epidemic exposure on trust in scientists seems to be driven by countries with below median physicians per capita at the time of the epidemic and low-income countries. This pattern is in line with evidence from Aksoy et al. (2020), who find that people in the low-income countries more likely to see their governments and leaders less trustworthy and unreliable when they are exposed to epidemics during their impressionable years.

\subsection{Are the results driven by the intensive or extensive margin?}

In Appendix Table A10, we distinguish the intensive and extensive margins of the treatment. For the extensive margin, we mean whether the effect is due to any level of epidemic exposure. To capture this, we construct a binary variable based on whether the number of people affected by epidemics during the individual's impressionable years is positive or zero. For the intensive margin, we limit the sample to individuals with positive epidemic exposure in their impressionable years.

Appendix Table A10 shows that the treatment works via the intensive margin. It is not simply being exposed to an epidemic that generates the effect; rather, conditional on being exposed, the severity of the epidemic drives the results.

\subsection{Are large epidemics different?}

As shown in Appendix Table A10, the effects we identify are driven by intensive margin. To further investigate this, in Appendix Table A11, we use indicators for the top $0.5 \%$ of exposures to epidemics, the top $1 \%$, the top $2 \%$, and the top $5 \%$, each in a separate estimation. An epidemic exposure in the scale of top $0.5,1$, or $2 \%$ of all past experiences causes a significant fall in an individual's confidence in scientists. Moreover, the magnitude of the effect tends to increase with more intense experiences.

\subsection{Excluding potential "bad controls"}

One might worry that certain individual characteristics (such as household income) are themselves affected by epidemic related economic shocks. We therefore checked for potential "bad controls" (Angrist and Pischke, 2009) by excluding these individual characterisitics. Doing so does not substantively change the point estimates for our variables of interest (see Appendix Table A12). ${ }^{16}$

\subsection{Robutness to controlling for the number of epidemic experience}

Table A13 shows that our results are robust to controlling for the number of epidemics experienced by individuals over their lifetime.

\subsection{Robustness to excluding most affected countries}

To check whether our results are driven by a small set of countries, we exclude the most affected countries and reestimate our main models. The results presented in Appendix Table A14 show that our results remain robust.

\section{Discussion}

COVID-19 has the potential to reshape every aspect of society, including how science and scientists are perceived. It is not clear, however, whether trust in science and scientists will be enhanced or diminished, or whether such changes will affect mainly science as an endeavor or scientists as individuals.

If past epidemics are a guide, the virus will not have an impact on the regard in which science as an undertaking is held. Members of the public will continue to believe that science has the potential to improve society. However, it will reduce trust in individual scientists, worsen perceptions of their honesty, and weaken the belief that their activities benefit the public. This distinction is consistent with the literatures in psychology and cognitive science on how individuals assign blame in complex, high-stakes social settings and with their tendency to blame individuals rather than institutions (see e.g. Wright, 1993; Wilinson-Ryan, 2020). It is consistent with what we observe in, inter alia, the United States, where politicians and commentators have questioned the value of the publicpolicy recommendations offered by individual scientists (viz. Senator Rand Paul's comment "As much as I respect you, Dr. Fauci, I

\footnotetext{
${ }^{16}$ We therefore keep these controls in our baseline specification to avoid omitted variable bias.
} 
don't think you're the end-all") while at the same time seeking to mobilize all available scientific resources to develop a vaccine (the Trump Administration's “Operation Warp Speed”).

Whether evidence from past epidemics provide an accurate guide to the likely effects on trust in scientists of COVID-19 can be questioned of course. The spread of COVID-19 is global, where some past epidemics were limited to a handful of countries. COVID-19 is arguably the first epidemic to occur in the era of widespread social media, which may have an effect on the spread of misinformation as well as information and on the formulation of opinions. We cannot speak definitively to this question of external validity. Our results in this paper however hold for epidemics that strike multiple countries as well as for those that are limited to a small number of countries.

The State of Science Index (2018) survey suggests that scientists are distrusted because they are seen as members of the elite. It suggests individuals feel that scientists, being self-interested and human, can be unduly influenced by government and corporate agendas, or because they feel that scientists' conclusions are based on personal beliefs and data. Our finding that past epidemic exposure negatively affects views of scientists working for private companies but not as much of scientists working for universities suggests that suspicion of corporate agendas is especially salient in this connection. That epidemic exposure affects views of scientists but not of science is consistent with this emphasis on investigator agendas and beliefs, insofar as bias due to self interest more plausibly skews results when a study is undertaken by an individual than a large team, in the latter case cancelling out individual biases (Dieckmann and Johnson, 2019). Still other surveys find that a significant share of respondents take disagreement among scientists, which is not unlikely in the context of a swiftly unfolding pandemic, as evidence that their conclusions are based on personal belief (rather than on issues of data and methodology), or as simply indicating that the investigators in question are incompetent.

Addressing concerns about corporate agendas, personal bias and disagreement in scientific communication is even more important in this light. Our results suggest that it is especially important to tailor any such response to the concerns expressed by members of the generation ("Generation Z") currently in their impressionable years.

\section{Appendix A}

See Tables A1-A18.

Table A1

Robustness to Controlling for Other Economic, Education Related and Political Shocks.

\begin{tabular}{|c|c|c|}
\hline & $(1)$ & $(2)$ \\
\hline Outcome $\rightarrow$ & Trust in scientists & Trust in scientists \\
\hline \multirow[t]{2}{*}{ Exposure to epidemic (18-25) } & $-1.548^{* * *}$ & $-1.839^{* * *}$ \\
\hline & $(0.528)$ & $(0.570)$ \\
\hline Observations & 30,666 & 30,666 \\
\hline Outcome $\rightarrow$ & Scientists working for private companies benefit the public & Scientists working for private companies benefit the public \\
\hline \multirow{2}{*}{ Exposure to epidemic (18-25) } & -0.738 & -0.837 \\
\hline & $(1.030)$ & $(1.167)$ \\
\hline Observations & 30,273 & 30,273 \\
\hline Outcome $\rightarrow$ & Scientists working for private companies are honest & Scientists working for private companies are honest \\
\hline \multirow[t]{2}{*}{ Exposure to epidemic (18-25) } & $-2.001^{* * *}$ & $-2.465^{* * *}$ \\
\hline & $(0.387)$ & $(0.573)$ \\
\hline Observations & 28,789 & 28,789 \\
\hline Outcome $\rightarrow$ & Scientists working for universities benefit the public & Scientists working for universities benefit the public \\
\hline \multirow[t]{2}{*}{ Exposure to epidemic (18-25) } & $-2.616^{* * *}$ & $-2.684^{* * *}$ \\
\hline & $(0.634)$ & $(0.748)$ \\
\hline Observations & 30,067 & 30,067 \\
\hline Outcome $\rightarrow$ & Scientists working for universities are honest & Scientists working for universities are honest \\
\hline \multirow[t]{2}{*}{ Exposure to epidemic (18-25) } & $-4.007^{* * *}$ & $-3.841^{* * *}$ \\
\hline & $(1.183)$ & $(1.214)$ \\
\hline Observations & 28,437 & 28,437 \\
\hline Outcome $\rightarrow$ & Scientists find out accurate information & Scientists find out accurate information \\
\hline \multirow[t]{2}{*}{ Exposure to epidemic (18-25) } & $-1.551^{* * *}$ & $-0.974^{* *}$ \\
\hline & $(0.373)$ & $(0.456)$ \\
\hline Observations & 30,980 & 30,980 \\
\hline Country fixed effects & Yes & Yes \\
\hline Cohort fixed effects & Yes & Yes \\
\hline Demographic characteristics & Yes & Yes \\
\hline Income quintile fixed effects & Yes & Yes \\
\hline Labour market controls & Yes & Yes \\
\hline Country-specific age trends & Yes & Yes \\
\hline Past controls (18-25) & No & Yes \\
\hline
\end{tabular}

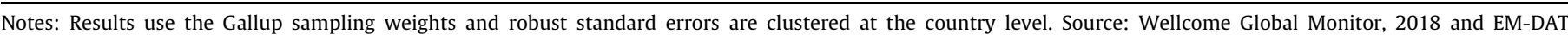
International Disaster Database, 1970-2017.

* significant at $10 \%$; ${ }^{* *}$ significant at $5 \%$; ${ }^{* * *}$ significant at $1 \%$. 
Table A2

Robustness to Omitted Variable Bias.

\begin{tabular}{|c|c|c|c|c|c|c|}
\hline Dependent variable: & $\begin{array}{l}(1) \\
\text { Trust in } \\
\text { scientists }\end{array}$ & $\begin{array}{l}\text { (2) } \\
\text { Scientists working for } \\
\text { private companies benefit } \\
\text { the public }\end{array}$ & $\begin{array}{l}(3) \\
\text { Scientists working for } \\
\text { private companies are } \\
\text { honest }\end{array}$ & $\begin{array}{l}\text { (4) } \\
\text { Scientists working for } \\
\text { universities benefit the } \\
\text { public }\end{array}$ & $\begin{array}{l}\text { (5) } \\
\text { Scientists working } \\
\text { for universities are } \\
\text { honest }\end{array}$ & $\begin{array}{l}\text { (6) } \\
\text { Scientists to find } \\
\text { out accurate } \\
\text { information }\end{array}$ \\
\hline $\begin{array}{l}\text { Exposure to Epidemic } \\
\qquad(18-25)\end{array}$ & $-3.454^{* *}$ & $-1.283^{* * *}$ & $-1.731^{* * *}$ & -0.616 & $-3.330^{* * *}$ & $-1.438^{* *}$ \\
\hline $\begin{array}{l}\text { Bounds on the } \\
\text { treatment effect } \\
\left(\delta=1, \operatorname{Rmax}=1.3^{*} \mathrm{R}\right)\end{array}$ & $\begin{array}{l}(1.330) \\
(-3.454 \\
-3.044)\end{array}$ & $\begin{array}{l}(0.338) \\
(-1.238,-1.134)\end{array}$ & $\begin{array}{l}(0.642) \\
(-1.731,-2.301)\end{array}$ & $\begin{array}{l}(0.478) \\
(-0.616,0.649)\end{array}$ & $\begin{array}{l}(0.446) \\
(-3.330,-2.587)\end{array}$ & $\begin{array}{l}(0.664) \\
(-1.438,-0.827)\end{array}$ \\
\hline $\begin{array}{l}\text { Treatment effect } \\
\text { excludes } 0\end{array}$ & Yes & Yes & Yes & Yes & Yes & Yes \\
\hline Delta $\left(\mathrm{Rmax}=1.3^{*} \mathrm{R}\right)$ & -44.41 & -132.15 & 13.52 & -1.97 & -39.39 & -5.367 \\
\hline
\end{tabular}

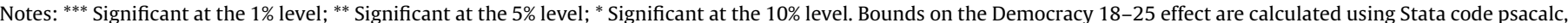

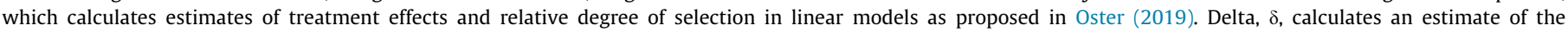

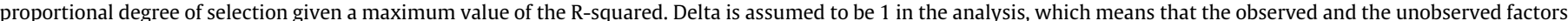

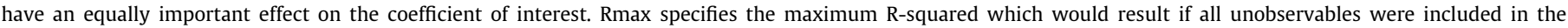
regression. We define Rmax upper bound as 1.3 times the R-squared from the main specification that controls for all observables.

Table A3

The Impact of Exposure to Epidemic on Trust in Scientists During Formative Years (18-25) vs. During Other Years.

\begin{tabular}{|c|c|c|c|c|c|}
\hline Outcome $\rightarrow$ & $\begin{array}{l}\text { (1) } \\
\text { Trust in scientists }\end{array}$ & $\begin{array}{l}\text { (2) } \\
\text { Trust in scientists }\end{array}$ & $\begin{array}{l}\text { (3) } \\
\text { Trust in scientists }\end{array}$ & $\begin{array}{l}\text { (4) } \\
\text { Trust in scientists }\end{array}$ & $\begin{array}{l}\text { (5) } \\
\text { Trust in scientists }\end{array}$ \\
\hline Exposure to Epidemic (18-25) & $\begin{array}{l}-3.454^{* *} \\
(1.330)\end{array}$ & $\begin{array}{l}-4.433^{* *} \\
(1.915)\end{array}$ & $\begin{array}{l}-3.086^{* *} \\
(1.184)\end{array}$ & $\begin{array}{l}-2.361^{* * *} \\
(0.836)\end{array}$ & $\begin{array}{l}-6.326^{* * *} \\
(1.023)\end{array}$ \\
\hline Exposure to Epidemic (2-9) & & $\begin{array}{l}-0.044 \\
(0.990)\end{array}$ & & & \\
\hline Exposure to Epidemic (10-17) & & & $\begin{array}{l}0.078 \\
(0.942)\end{array}$ & & \\
\hline Exposure to Epidemic (26-33) & & & & $\begin{array}{l}-0.753 \\
(1.152)\end{array}$ & \\
\hline Exposure to Epidemic (34-42) & & & & & -0.932 \\
\hline Observations & 82,854 & 58,284 & 71,109 & 60,943 & 42,018 \\
\hline Country fixed effects & Yes & Yes & Yes & Yes & Yes \\
\hline Cohort fixed effects & Yes & Yes & Yes & Yes & Yes \\
\hline Demographic characteristics & Yes & Yes & Yes & Yes & Yes \\
\hline Income quintile fixed effects & Yes & Yes & Yes & Yes & Yes \\
\hline Labour market controls & Yes & Yes & Yes & Yes & Yes \\
\hline Country-specific age trends & Yes & Yes & Yes & Yes & Yes \\
\hline
\end{tabular}

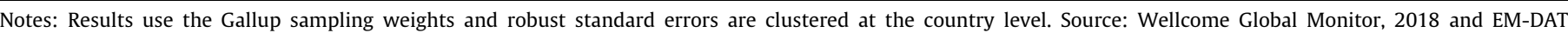
International Disaster Database, $1970-2017 .{ }^{*}$ significant at $10 \% ;{ }^{* *}$ significant at $5 \% ;{ }^{* * *}$ significant at $1 \%$.

Table A4

Multiple Hypothesis Testing on Variables Related to Trust in Scientists.

$\begin{array}{ll}\text { Randomization-c p-values (joint test of treatment significance) } & 0.005^{* * *} \\ \text { Randomization-t p-values (joint test of treatment significance) } & \mathrm{N} / \mathrm{A} \\ \text { Randomization-c p-values (Westfall-Young multiple testing of treatment significance) } & 0.037^{* *} \\ \text { Randomization-t p-values (Westfall-Young multiple testing of treatment significance) } & 0.020^{* *}\end{array}$

Notes: * significant at $10 \% ;{ }^{* *}$ significant at $5 \% ;{ }^{* * *}$ significant at $1 \%$. Randomization-t technique does not produce p-values for the joint test of treatment significance. Results are derived from 100 iterations. Specification is Column 3 of Table 1. Source: Wellcome Global Monitor, 2018 and EM-DAT International Disaster Database, 1970-2017. 
Table A5

Robustness to Using Population Unadjusted Treatment Variable - Trust in Scientists.

\begin{tabular}{|c|c|c|c|c|c|c|}
\hline & $(1)$ & $(2)$ & (3) & $(4)$ & (5) & (6) \\
\hline \multicolumn{7}{|l|}{ Outcome $\rightarrow$ Trust in scientists } \\
\hline \multirow[t]{2}{*}{ Exposure to Epidemic (18-25) nopop. } & -0.067 & -0.060 & $-0.095^{* *}$ & $-0.089^{* *}$ & $-0.079^{*}$ & $-0.093^{* *}$ \\
\hline & $(0.042)$ & $(0.043)$ & $(0.043)$ & $(0.043)$ & $(0.044)$ & $(0.042)$ \\
\hline Observations & 85,746 & 85,586 & 85,586 & 85,586 & 85,586 & 85,586 \\
\hline \multicolumn{7}{|c|}{ Outcome $\rightarrow$ Scientists working for private companies benefit the public } \\
\hline \multirow[t]{2}{*}{ Exposure to Epidemic $(18-25)_{\text {nopop. }}$} & $-0.043^{*}$ & $-0.045^{*}$ & $-0.060^{* * *}$ & $-0.057^{* * *}$ & $-0.048^{* *}$ & $-0.058^{* * *}$ \\
\hline & $(0.026)$ & $(0.024)$ & $(0.017)$ & $(0.020)$ & $(0.021)$ & $(0.017)$ \\
\hline Observations & 84,228 & 84,080 & 84,080 & 84,080 & 84,080 & 84,080 \\
\hline \multicolumn{7}{|c|}{ Outcome $\rightarrow$ Scientists working for private companies are honest } \\
\hline \multirow[t]{2}{*}{ Exposure to Epidemic (18-25) nopop. } & $-0.092^{* * *}$ & $-0.093^{* * *}$ & $-0.096^{* * *}$ & $-0.105^{* * *}$ & $-0.086^{* * *}$ & $-0.091^{* * *}$ \\
\hline & $(0.025)$ & $(0.025)$ & $(0.013)$ & $(0.014)$ & $(0.016)$ & $(0.015)$ \\
\hline Observations & 79,312 & 79,179 & 79,179 & 79,179 & 79,179 & 79,179 \\
\hline \multicolumn{7}{|c|}{ Outcome $\rightarrow$ Scientists working for universities benefit the public } \\
\hline \multirow[t]{2}{*}{ Exposure to Epidemic (18-25) nopop. } & 0.031 & 0.034 & $-0.037^{*}$ & $-0.044^{*}$ & -0.034 & $-0.041^{* *}$ \\
\hline & $(0.024)$ & $(0.024)$ & $(0.022)$ & $(0.023)$ & $(0.024)$ & $(0.020)$ \\
\hline Observations & 83,930 & 83,770 & 83,770 & 83,770 & 83,770 & 83,770 \\
\hline \multicolumn{7}{|c|}{ Outcome $\rightarrow$ Scientists working for universities are honest } \\
\hline \multirow[t]{2}{*}{ Exposure to Epidemic (18-25) nopop. } & $-0.106^{* * *}$ & $-0.101^{* * *}$ & $-0.143^{* * *}$ & $-0.148^{* * *}$ & $-0.139^{* * *}$ & $-0.144^{* * *}$ \\
\hline & $(0.030)$ & $(0.031)$ & $(0.023)$ & $(0.024)$ & $(0.027)$ & $(0.022)$ \\
\hline Observations & 78,540 & 78,409 & 78,409 & 78,409 & 78,409 & 78,409 \\
\hline \multicolumn{7}{|c|}{ Outcome $\rightarrow$ Scientists to find out accurate information } \\
\hline Exposure to Epidemic (18-25) nopop. & $\begin{array}{r}-0.022 \\
(0.040)\end{array}$ & $\begin{array}{l}-0.012 \\
(0.044)\end{array}$ & $\begin{array}{l}-0.060 \\
(0.042)\end{array}$ & $\begin{array}{l}-0.078^{*} \\
(0.042)\end{array}$ & $\begin{array}{l}-0.047 \\
(0.045)\end{array}$ & $\begin{array}{l}-0.066 \\
(0.042)\end{array}$ \\
\hline Observations & 86,857 & 86,692 & 86,692 & 86,692 & 86,692 & 86,692 \\
\hline Country fixed effects & Yes & Yes & Yes & No & No & No \\
\hline Cohort fixed effects & Yes & Yes & Yes & Yes & Yes & Yes \\
\hline Demographic characteristics & No & Yes & Yes & Yes & Yes & Yes \\
\hline Income quintile fixed effects & No & Yes & Yes & No & Yes & Yes \\
\hline Labour market controls & No & Yes & Yes & Yes & No & Yes \\
\hline Country-specific age trends & No & No & Yes & Yes & Yes & Yes \\
\hline Country* Income fixed effects & No & No & No & Yes & No & No \\
\hline Country*Empl. fixed effects & No & No & No & No & Yes & No \\
\hline Country*Educ. fixed effects & No & No & No & No & No & Yes \\
\hline
\end{tabular}

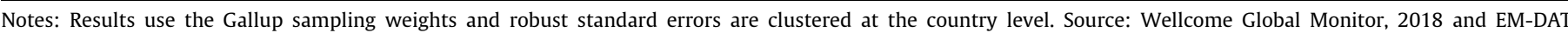
International Disaster Database, 1970-2017. * significant at 10\%; ${ }^{* *}$ significant at 5\%; ${ }^{* * *}$ significant at $1 \%$.

Table A6

Robustness to Using Population Unadjusted Treatment Variable - Trust in Science and Placebo Outcomes.

\begin{tabular}{|c|c|c|c|c|c|c|}
\hline & (1) & $(2)$ & (3) & $(4)$ & (5) & (6) \\
\hline \multicolumn{7}{|l|}{ Outcome $\rightarrow$ Have trust in science } \\
\hline Exposure to Epidemic $(18-25)_{\text {nopop. }}$ & $\begin{array}{l}-0.000 \\
(0.031)\end{array}$ & $\begin{array}{l}0.009 \\
(0.032)\end{array}$ & $\begin{array}{l}-0.025 \\
(0.043)\end{array}$ & $\begin{array}{l}-0.039 \\
(0.040)\end{array}$ & $\begin{array}{l}-0.009 \\
(0.044)\end{array}$ & $\begin{array}{l}-0.028 \\
(0.043)\end{array}$ \\
\hline Observations & 88,129 & 87,960 & 87,960 & 87,960 & 87,960 & 87,960 \\
\hline \multicolumn{7}{|c|}{ Outcome $\rightarrow$ Science and technology will help improve life } \\
\hline Exposure to Epidemic (18-25) nopop. & $\begin{array}{l}0.013 \\
(0.031)\end{array}$ & $\begin{array}{l}0.018 \\
(0.032)\end{array}$ & $\begin{array}{l}-0.004 \\
(0.038)\end{array}$ & $\begin{array}{l}-0.008 \\
(0.037)\end{array}$ & $\begin{array}{l}0.003 \\
(0.041)\end{array}$ & $\begin{array}{l}-0.004 \\
(0.037)\end{array}$ \\
\hline Observations & 89,271 & 89,083 & 89,083 & 89,083 & 89,083 & 89,083 \\
\hline \multicolumn{7}{|c|}{ Outcome $\rightarrow$ Studying diseases is a part of science } \\
\hline Exposure to Epidemic $(18-25)_{\text {nopop. }}$ & $\begin{array}{l}-0.032 \\
(0.026)\end{array}$ & $\begin{array}{l}-0.026 \\
(0.025)\end{array}$ & $\begin{array}{l}0.003 \\
(0.024)\end{array}$ & $\begin{array}{l}-0.005 \\
(0.023)\end{array}$ & $\begin{array}{l}0.007 \\
(0.024)\end{array}$ & $\begin{array}{l}0.008 \\
(0.025)\end{array}$ \\
\hline $\begin{array}{l}\text { Observations } \\
\text { Outcome } \rightarrow \text { Have trust in doctors an }\end{array}$ & 91,104 & 90,916 & 90,916 & 90,916 & 90,916 & 90,916 \\
\hline Exposure to Epidemic (18-25) nopop. & $\begin{array}{l}0.083^{* *} \\
(0.037)\end{array}$ & $\begin{array}{l}0.083^{* *} \\
(0.037)\end{array}$ & $\begin{array}{l}0.079 \\
(0.042)\end{array}$ & $\begin{array}{l}0.076 \\
(0.047)\end{array}$ & $\begin{array}{l}0.073^{*} \\
(0.042)\end{array}$ & $\begin{array}{l}0.073^{*} \\
(0.044)\end{array}$ \\
\hline Observations & 95,061 & 94,870 & 94,870 & 94,870 & 94,870 & 94,870 \\
\hline \multicolumn{7}{|c|}{ Outcome $\rightarrow$ Have trust in hospitals and health clinics } \\
\hline Exposure to Epidemic (18-25) nopop. & $\begin{array}{l}0.077^{* *} \\
(0.036)\end{array}$ & $\begin{array}{l}0.074^{* *} \\
(0.034)\end{array}$ & $\begin{array}{l}0.117^{* * *} \\
(0.022)\end{array}$ & $\begin{array}{l}0.122^{* * *} \\
(0.025)\end{array}$ & $\begin{array}{l}0.104^{* * *} \\
(0.023)\end{array}$ & $\begin{array}{l}0.115^{* * *} \\
(0.023)\end{array}$ \\
\hline Observations & 92,985 & 92,806 & 92,806 & 92,806 & 92,806 & 92,806 \\
\hline $\begin{array}{l}\text { Outcome } \rightarrow \text { Have trust in traditional } \\
\text { Exposure to Epidemic }(18-25)_{\text {nopop. }}\end{array}$ & $\begin{array}{l}0.042 \\
(0.042)\end{array}$ & $\begin{array}{l}0.034 \\
(0.041)\end{array}$ & $\begin{array}{l}-0.010 \\
(0.019)\end{array}$ & $\begin{array}{l}-0.015 \\
(0.025)\end{array}$ & $\begin{array}{l}-0.022 \\
(0.018)\end{array}$ & $\begin{array}{l}-0.008 \\
(0.019)\end{array}$ \\
\hline Observations & 90,775 & 90,594 & 90,594 & 90,594 & 90,594 & 90,594 \\
\hline Country fixed effects & Yes & Yes & Yes & No & No & No \\
\hline Cohort fixed effects & Yes & Yes & Yes & Yes & Yes & Yes \\
\hline Demographic characteristics & No & Yes & Yes & Yes & Yes & Yes \\
\hline Income quintile fixed effects & No & Yes & Yes & No & Yes & Yes \\
\hline Labour market controls & No & Yes & Yes & Yes & No & Yes \\
\hline Country-specific age trends & No & No & Yes & Yes & Yes & Yes \\
\hline Country*Income fixed effects & No & No & No & Yes & No & No \\
\hline Country*Empl. fixed effects & No & No & No & No & Yes & No \\
\hline Country*Educ. fixed effects & No & No & No & No & No & Yes \\
\hline
\end{tabular}

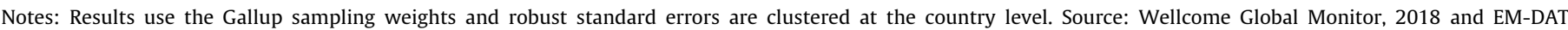
International Disaster Database, 1970-2017. * significant at 10\%; ${ }^{* *}$ significant at $5 \%$; ${ }^{* * *}$ significant at $1 \%$. 
Table A7

Robustness to Using Treatment Variable with a Fixed Population in 1970 - Trust in Scientists.

\begin{tabular}{|c|c|c|c|c|c|c|}
\hline & $(1)$ & $(2)$ & (3) & $(4)$ & $(5)$ & (6) \\
\hline \multicolumn{7}{|l|}{ Outcome $\rightarrow$ Trust in scientists } \\
\hline \multirow{2}{*}{ Exposure to Epidemic (18-25) pop70 } & -1.277 & -1.226 & $-1.546^{* *}$ & $-1.521^{*}$ & $-1.402^{*}$ & $-1.567^{* *}$ \\
\hline & $(0.825)$ & $(0.848)$ & $(0.745)$ & $(0.783)$ & $(0.797)$ & $(0.780)$ \\
\hline Observations & 83,014 & 82,854 & 82,854 & 82,854 & 82,854 & 82,854 \\
\hline \multicolumn{7}{|c|}{ Outcome $\rightarrow$ Scientists working for private companies benefit the public } \\
\hline Exposure to Epidemic (18-25) pop70 & $\begin{array}{l}-0.743^{* * *} \\
(0.173)\end{array}$ & $\begin{array}{l}-0.750^{* * *} \\
(0.177)\end{array}$ & $\begin{array}{l}-0.624^{* * *} \\
(0.156)\end{array}$ & $\begin{array}{l}-0.611^{* * *} \\
(0.194)\end{array}$ & $\begin{array}{l}-0.530^{* *} \\
(0.226)\end{array}$ & $\begin{array}{l}-0.645^{* * *} \\
(0.179)\end{array}$ \\
\hline Observations & 81,554 & 81,406 & 81,406 & 81,406 & 81,406 & 81,406 \\
\hline \multicolumn{7}{|c|}{ Outcome $\rightarrow$ Scientists working for private companies are honest } \\
\hline Exposure to Epidemic $(18-25)_{\text {pop70 }}$ & $\begin{array}{l}-0.989^{* * *} \\
(0.226)\end{array}$ & $\begin{array}{l}-0.996^{* * *} \\
(0.227)\end{array}$ & $\begin{array}{l}-0.811^{\text {**** }} \\
(0.261)\end{array}$ & $\begin{array}{l}-0.895^{* * *} \\
(0.266)\end{array}$ & $\begin{array}{l}-0.716^{* * *} \\
(0.207)\end{array}$ & $\begin{array}{l}-0.820^{* * *} \\
(0.259)\end{array}$ \\
\hline Observations & 76,856 & 76,723 & 76,723 & 76,723 & 76,723 & 76,723 \\
\hline \multicolumn{7}{|c|}{ Outcome $\rightarrow$ Scientists working for universities benefit the public } \\
\hline Exposure to Epidemic $(18-25)_{\text {pop70 }}$ & $\begin{array}{l}0.112 \\
(0.345)\end{array}$ & $\begin{array}{l}0.145 \\
(0.358)\end{array}$ & $\begin{array}{l}-0.261 \\
(0.194)\end{array}$ & $\begin{array}{l}-0.350^{*} \\
(0.192)\end{array}$ & $\begin{array}{l}-0.232 \\
(0.205)\end{array}$ & $\begin{array}{l}-0.347^{*} \\
(0.185)\end{array}$ \\
\hline Observations & 81,307 & 81,147 & 81,147 & 81,147 & 81,147 & 81,147 \\
\hline \multicolumn{7}{|c|}{ Outcome $\rightarrow$ Scientists working for universities are honest } \\
\hline Exposure to Epidemic $(18-25)_{\text {pop70 }}$ & $\begin{array}{l}-1.367^{* * *} \\
(0.260)\end{array}$ & $\begin{array}{l}-1.334^{* * *} \\
(0.279)\end{array}$ & $\begin{array}{l}-1.515^{* * * *} \\
(0.166)\end{array}$ & $\begin{array}{l}-1.563^{* * *} \\
(0.172)\end{array}$ & $\begin{array}{l}-1.455^{* * * *} \\
(0.175)\end{array}$ & $\begin{array}{l}-1.527^{* * *} \\
(0.176)\end{array}$ \\
\hline Observations & 76,123 & 75,992 & 75,992 & 75,992 & 75,992 & 75,992 \\
\hline \multicolumn{7}{|c|}{ Outcome $\rightarrow$ Scientists to find out accurate information } \\
\hline Exposure to Epidemic (18-25) pop70 & $\begin{array}{l}-0.526 \\
(0.487)\end{array}$ & $\begin{array}{l}-0.447 \\
(0.555)\end{array}$ & $\begin{array}{l}-0.581^{*} \\
(0.342)\end{array}$ & $\begin{array}{l}-0.783^{* *} \\
(0.345)\end{array}$ & $\begin{array}{l}-0.455 \\
(0.373)\end{array}$ & $\begin{array}{l}-0.695^{*} \\
(0.376)\end{array}$ \\
\hline Observations & 84,104 & 83,939 & 83,939 & 83,939 & 83,939 & 83,939 \\
\hline Country fixed effects & Yes & Yes & Yes & No & No & No \\
\hline Cohort fixed effects & Yes & Yes & Yes & Yes & Yes & Yes \\
\hline Demographic characteristics & No & Yes & Yes & Yes & Yes & Yes \\
\hline Income quintile fixed effects & No & Yes & Yes & No & Yes & Yes \\
\hline Labour market controls & No & Yes & Yes & Yes & No & Yes \\
\hline Country-specific age trends & No & No & Yes & Yes & Yes & Yes \\
\hline Country*Income fixed effects & No & No & No & Yes & No & No \\
\hline Country*Empl. fixed effects & No & No & No & No & Yes & No \\
\hline Country*Educ. fixed effects & No & No & No & No & No & Yes \\
\hline
\end{tabular}

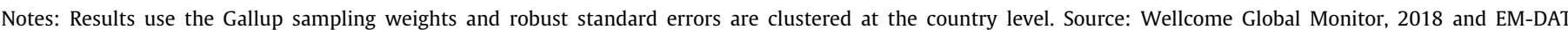
International Disaster Database, 1970-2017. ${ }^{*}$ significant at $10 \% ;{ }^{* *}$ significant at $5 \%$; ${ }^{* * *}$ significant at $1 \%$.

Table A8

Robustness to Using Treatment Variable with a Fixed Population in 1970 - Trust in Science and Placebo Outcomes.

\begin{tabular}{|c|c|c|c|c|c|c|}
\hline & (1) & $(2)$ & (3) & (4) & (5) & (6) \\
\hline \multicolumn{7}{|l|}{ Outcome $\rightarrow$ Have trust in science } \\
\hline Exposure to Epidemic (18-25) pop70 & $\begin{array}{l}0.073 \\
(0.231)\end{array}$ & $\begin{array}{l}0.133 \\
(0.281)\end{array}$ & $\begin{array}{l}0.112 \\
(0.188)\end{array}$ & $\begin{array}{l}-0.036 \\
(0.212)\end{array}$ & $\begin{array}{l}0.255 \\
(0.190)\end{array}$ & $\begin{array}{l}0.069 \\
(0.191)\end{array}$ \\
\hline Observations & 85,368 & 85,199 & 85,199 & 85,199 & 85,199 & 85,199 \\
\hline \multicolumn{7}{|c|}{ Outcome $\rightarrow$ Science and technology will help improve life } \\
\hline Exposure to Epidemic (18-25) pop70 & $\begin{array}{l}0.290^{*} \\
(0.151)\end{array}$ & $\begin{array}{l}0.338^{* *} \\
(0.155)\end{array}$ & $\begin{array}{l}0.360 \\
(0.213)\end{array}$ & $\begin{array}{l}0.334 \\
(0.228)\end{array}$ & $\begin{array}{l}0.398 \\
(0.209)\end{array}$ & $\begin{array}{l}0.345 \\
(0.212)\end{array}$ \\
\hline Observations & 0.041 & 0.049 & 0.052 & 0.064 & 0.067 & 0.060 \\
\hline \multicolumn{7}{|c|}{ Outcome $\rightarrow$ Studying diseases is a part of science } \\
\hline Exposure to Epidemic (18-25) pop70 & $\begin{array}{l}0.005 \\
(0.259)\end{array}$ & $\begin{array}{l}0.043 \\
(0.219)\end{array}$ & $\begin{array}{l}0.139 \\
(0.192)\end{array}$ & $\begin{array}{l}0.040 \\
(0.147)\end{array}$ & $\begin{array}{l}0.184 \\
(0.177)\end{array}$ & $\begin{array}{l}0.167 \\
(0.183)\end{array}$ \\
\hline \multicolumn{6}{|c|}{ Outcome $\rightarrow$ Have trust in doctors and nurses } & 88,138 \\
\hline Exposure to Epidemic $(18-25)_{\text {pop70 }}$ & $\begin{array}{l}0.693 \\
(0.541)\end{array}$ & $\begin{array}{l}0.706 \\
(0.533)\end{array}$ & $\begin{array}{l}0.829^{*} \\
(0.471)\end{array}$ & $\begin{array}{l}0.774 \\
(0.556)\end{array}$ & $\begin{array}{l}0.791^{*} \\
(0.438)\end{array}$ & $\begin{array}{l}0.752 \\
(0.496)\end{array}$ \\
\hline Observations & 92,026 & 91,835 & 91,835 & 91,835 & 91,835 & 91,835 \\
\hline \multicolumn{7}{|c|}{ Outcome $\rightarrow$ Have trust in hospitals and health clinics } \\
\hline Exposure to Epidemic $(18-25)_{\text {pop70 }}$ & $\begin{array}{l}0.421 \\
(0.652)\end{array}$ & $\begin{array}{l}0.435 \\
(0.604)\end{array}$ & $\begin{array}{l}0.714 \\
(0.531)\end{array}$ & $\begin{array}{l}0.793 \\
(0.633)\end{array}$ & $\begin{array}{l}0.607 \\
(0.499)\end{array}$ & $\begin{array}{l}0.678 \\
(0.557)\end{array}$ \\
\hline Observations & 90,030 & 89,851 & 89,851 & 89,851 & 89,851 & 89,851 \\
\hline $\begin{array}{l}\text { Outcome } \rightarrow \text { Have trust in traditiona } \\
\text { Exposure to Epidemic }(18-25)_{\text {pop } 70}\end{array}$ & $\begin{array}{l}0.130 \\
(0.475)\end{array}$ & $\begin{array}{l}0.090 \\
(0.433)\end{array}$ & $\begin{array}{c}-0.294 \\
(0.264)\end{array}$ & $\begin{array}{c}-0.278 \\
(0.250)\end{array}$ & $\begin{array}{l}-0.453^{*} \\
(0.233)\end{array}$ & $\begin{array}{l}-0.271 \\
(0.258)\end{array}$ \\
\hline Observations & 87,942 & 87,761 & 87,761 & 87,761 & 87,761 & 87,761 \\
\hline Country fixed effects & Yes & Yes & Yes & No & No & No \\
\hline Cohort fixed effects & Yes & Yes & Yes & Yes & Yes & Yes \\
\hline Demographic characteristics & No & Yes & Yes & Yes & Yes & Yes \\
\hline Income quintile fixed effects & No & Yes & Yes & No & Yes & Yes \\
\hline Labour market controls & No & Yes & Yes & Yes & No & Yes \\
\hline Country-specific age trends & No & No & Yes & Yes & Yes & Yes \\
\hline
\end{tabular}


Table A8 (continued)

\begin{tabular}{|c|c|c|c|c|c|c|}
\hline & (1) & $(2)$ & (3) & (4) & (5) & (6) \\
\hline Country*Income fixed effects & No & No & No & Yes & No & No \\
\hline Country*Empl. fixed effects & No & No & No & No & Yes & No \\
\hline Country*Educ. fixed effects & No & No & No & No & No & Yes \\
\hline
\end{tabular}

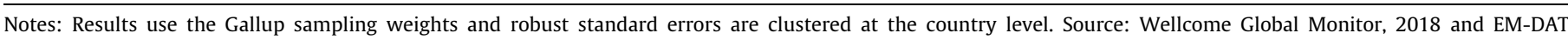
International Disaster Database, $1970-2017 .{ }^{*}$ significant at $10 \% ;{ }^{* *}$ significant at $5 \%$; ${ }^{* * *}$ significant at $1 \%$.

Table A9

The Impact of Exposure to Epidemic (18-25) on Confidence in Scientists - Country Level Heterogeneity.

\begin{tabular}{|c|c|c|c|c|c|c|}
\hline Outcome $\rightarrow$ & $\begin{array}{l}(1) \\
\text { Confidence } \\
\text { in scientists }\end{array}$ & $\begin{array}{l}\text { (2) } \\
\text { Scientists working for private } \\
\text { companies benefit the public }\end{array}$ & $\begin{array}{l}\text { (3) } \\
\text { Scientists working for } \\
\text { private companies are } \\
\text { honest }\end{array}$ & $\begin{array}{l}\text { (4) } \\
\text { Scientists working for } \\
\text { universities benefit the } \\
\text { public }\end{array}$ & $\begin{array}{l}\text { (5) } \\
\text { Scientists working for } \\
\text { universities are } \\
\text { honest }\end{array}$ & $\begin{array}{l}\text { (6) } \\
\text { Scientists to out } \\
\text { accurate } \\
\text { information }\end{array}$ \\
\hline \multicolumn{7}{|c|}{ Sample $\rightarrow$ Countries with below median physicians per capita at the time of the epidemic } \\
\hline \multirow[t]{2}{*}{$\begin{array}{l}\text { Exposure to } \\
\text { Epidemic } \\
(18-25)\end{array}$} & $-2.538^{* *}$ & -0.941 & -1.290 & $-1.480^{* * *}$ & $-3.821^{* * *}$ & $-1.500^{* * *}$ \\
\hline & $(1.198)$ & $(0.704)$ & $(1.880)$ & $(0.477)$ & $(0.920)$ & $(0.389)$ \\
\hline Observations & 23,471 & 22,897 & 21,429 & 22,657 & 21,188 & 23,457 \\
\hline \multicolumn{7}{|c|}{ Sample $\rightarrow$ Countries with above median physicians per capita at the time of the epidemic } \\
\hline \multirow[t]{2}{*}{$\begin{array}{l}\text { Exposure to } \\
\text { Epidemic } \\
(18-25)\end{array}$} & 8.534 & 3.150 & 23.543 & 3.551 & -2.854 & -10.120 \\
\hline & $(8.792)$ & $(19.549)$ & $(19.378)$ & $(17.570)$ & $(20.983)$ & $(15.787)$ \\
\hline Observations & 24,971 & 24,950 & 23,849 & 24,936 & 23,538 & 25,752 \\
\hline \multicolumn{7}{|c|}{ Sample $\rightarrow$ Countries with below median-income at the time of the epidemic } \\
\hline \multirow[t]{2}{*}{$\begin{array}{l}\text { Exposure to } \\
\text { Epidemic } \\
(18-25)\end{array}$} & $-3.385^{* *}$ & $-1.205^{* * *}$ & $-2.169^{* * *}$ & -0.653 & $-3.238^{* * *}$ & -0.833 \\
\hline & $(1.399)$ & $(0.416)$ & $(0.747)$ & $(0.642)$ & $(0.615)$ & $(0.611)$ \\
\hline Observations & 32,979 & 32,195 & 30,127 & 31,915 & 29,857 & 33,153 \\
\hline \multicolumn{7}{|c|}{ Sample $\rightarrow$ Countries with above median-income at the time of the epidemic } \\
\hline \multirow[t]{2}{*}{$\begin{array}{l}\text { Exposure to } \\
\text { Epidemic } \\
(18-25)\end{array}$} & -16.196 & -11.317 & 0.243 & -18.143 & -22.066 & $-26.570^{*}$ \\
\hline & (19.432) & $(20.752)$ & $(16.352)$ & $(11.706)$ & $(12.233)$ & (13.173) \\
\hline Observations & 34,116 & 33,929 & 32,465 & 33,963 & 32,155 & 34,984 \\
\hline
\end{tabular}

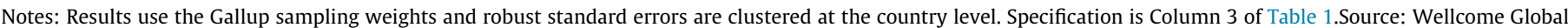
Monitor, 2018 and EM-DAT International Disaster Database, 1970-2017. * significant at 10\%; ${ }^{* *}$ significant at 5\%; ${ }^{* * *}$ significant at $1 \%$.

Table A10

The Impact of Exposure to Epidemic (18-25) on Trust in Scientists - Intensive and Extensive Margins.

\begin{tabular}{|c|c|c|c|c|c|c|}
\hline Outcome $\rightarrow$ & $\begin{array}{l}(1) \\
\text { Confidence } \\
\text { in scientists }\end{array}$ & $\begin{array}{l}(2) \\
\text { Scientists working for } \\
\text { private companies benefit } \\
\text { the public }\end{array}$ & $\begin{array}{l}\text { (3) } \\
\text { Scientists working for } \\
\text { private companies are } \\
\text { honest }\end{array}$ & $\begin{array}{l}\text { (4) } \\
\text { Scientists working for } \\
\text { universities benefit the } \\
\text { public }\end{array}$ & $\begin{array}{l}\text { (5) } \\
\text { Scientists working } \\
\text { for universities are } \\
\text { honest }\end{array}$ & $\begin{array}{l}\text { (6) } \\
\text { Scientists to find } \\
\text { out accurate } \\
\text { information }\end{array}$ \\
\hline \multicolumn{7}{|l|}{ Intensive margin } \\
\hline $\begin{array}{l}\text { Exposure to Epidemic } \\
\quad(18-25)\end{array}$ & $\begin{array}{l}-3.762^{*} \\
(2.233)\end{array}$ & $\begin{array}{l}-1.870^{* * *} \\
(0.389)\end{array}$ & $\begin{array}{l}-2.354^{* *} \\
(0.983)\end{array}$ & $\begin{array}{l}-2.782 \\
(1.986)\end{array}$ & $\begin{array}{l}-4.154^{* * *} \\
(0.916)\end{array}$ & $\begin{array}{l}-1.807^{* * *} \\
(0.348)\end{array}$ \\
\hline Observations & 35,807 & 34,932 & 32,912 & 34,673 & 32,542 & 35,805 \\
\hline \multicolumn{7}{|l|}{ Extensive margin } \\
\hline $\begin{array}{l}\text { Exposure to Epidemic } \\
\quad(18-25)\end{array}$ & $\begin{array}{l}0.001 \\
(0.006)\end{array}$ & $\begin{array}{l}-0.005 \\
(0.006)\end{array}$ & $\begin{array}{l}0.007 \\
(0.006)\end{array}$ & $\begin{array}{l}-0.002 \\
(0.006)\end{array}$ & $\begin{array}{l}0.001 \\
(0.005)\end{array}$ & $\begin{array}{l}-0.003 \\
(0.005)\end{array}$ \\
\hline Observations & 82,854 & 81,406 & 76,723 & 81,147 & 75,992 & 83,939 \\
\hline Country fixed effects & Yes & Yes & Yes & Yes & Yes & Yes \\
\hline Cohort fixed effects & Yes & Yes & Yes & Yes & Yes & Yes \\
\hline $\begin{array}{l}\text { Demographic } \\
\text { characteristics }\end{array}$ & Yes & Yes & Yes & Yes & Yes & Yes \\
\hline $\begin{array}{l}\text { Income quintile fixed } \\
\text { effects }\end{array}$ & Yes & Yes & Yes & Yes & Yes & Yes \\
\hline Labour market controls & Yes & Yes & Yes & Yes & Yes & Yes \\
\hline $\begin{array}{l}\text { Country-specific age } \\
\text { trends }\end{array}$ & Yes & Yes & Yes & Yes & Yes & Yes \\
\hline
\end{tabular}

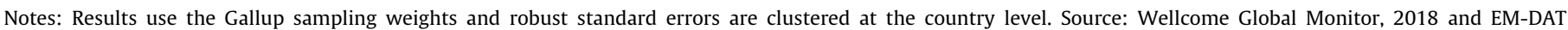
International Disaster Database, 1970-2017. * significant at $10 \% ;{ }^{* *}$ significant at 5\%; ${ }^{* * *}$ significant at $1 \%$. 
Table A11

The Impact of Exposure to Epidemic (18-25) on Trust in Scientists by Exposure Thresholds.

\begin{tabular}{|c|c|c|c|c|c|c|}
\hline Outcome $\rightarrow$ & $\begin{array}{l}(1) \\
\text { Confidence } \\
\text { in scientists }\end{array}$ & $\begin{array}{l}(2) \\
\text { Scientists working for } \\
\text { private companies benefit } \\
\text { the public }\end{array}$ & $\begin{array}{l}\text { (3) } \\
\text { Scientists working for } \\
\text { private companies are } \\
\text { honest }\end{array}$ & $\begin{array}{l}\text { (4) } \\
\text { Scientists working for } \\
\text { universities benefit the } \\
\text { public }\end{array}$ & $\begin{array}{l}(5) \\
\text { Scientists working for } \\
\text { universities are } \\
\text { honest }\end{array}$ & $\begin{array}{l}\text { (6) } \\
\text { Scientists to find out } \\
\text { accurate } \\
\text { information }\end{array}$ \\
\hline $\begin{array}{l}\text { Top } 0.5 \text { per cent } \\
\text { (Exposure to } \\
\text { Epidemic, } \\
18-25 \text { ) }\end{array}$ & $\begin{array}{l}-0.274^{* * *} \\
(0.014)\end{array}$ & $\begin{array}{l}-0.188^{* * *} \\
(0.015)\end{array}$ & $\begin{array}{l}-0.134^{* * *} \\
(0.016)\end{array}$ & $\begin{array}{l}0.008 \\
(0.014)\end{array}$ & $\begin{array}{l}-0.134^{* * *} \\
(0.016)\end{array}$ & $\begin{array}{l}0.008 \\
(0.014)\end{array}$ \\
\hline Observations & 27,212 & 26,639 & 25,102 & 26,644 & 25,102 & 26,644 \\
\hline $\begin{array}{l}\text { Top } 1 \text { per cent } \\
\text { (Exposure to } \\
\text { Epidemic, } \\
18-25 \text { ) }\end{array}$ & $\begin{array}{l}-0.125 \\
(0.085)\end{array}$ & $\begin{array}{l}-0.011 \\
(0.093)\end{array}$ & $\begin{array}{l}-0.136^{* * *} \\
(0.013)\end{array}$ & $\begin{array}{l}-0.018 \\
(0.018)\end{array}$ & $\begin{array}{l}-0.136^{* * *} \\
(0.013)\end{array}$ & $\begin{array}{l}-0.018 \\
(0.018)\end{array}$ \\
\hline Observations & 27,212 & 26,639 & 25,102 & 26,644 & 25,102 & 26,644 \\
\hline $\begin{array}{l}\text { Top } 2 \text { per cent } \\
\text { (Exposure to } \\
\text { Epidemic, } \\
18-25 \text { ) }\end{array}$ & $\begin{array}{l}-0.134^{* *} \\
(0.058)\end{array}$ & $\begin{array}{l}-0.113^{* *} \\
(0.056)\end{array}$ & $\begin{array}{l}-0.089^{*} \\
(0.052)\end{array}$ & $\begin{array}{l}-0.108 \\
(0.066)\end{array}$ & $\begin{array}{l}-0.089 * \\
(0.052)\end{array}$ & $\begin{array}{l}-0.108 \\
(0.066)\end{array}$ \\
\hline Observations & 27,212 & 26,639 & 25,102 & 26,644 & 25,102 & 26,644 \\
\hline $\begin{array}{l}\text { Top } 5 \text { per cent } \\
\text { (Exposure to } \\
\text { Epidemic, } \\
18-25 \text { ) }\end{array}$ & $\begin{array}{l}-0.024 \\
(0.030)\end{array}$ & $\begin{array}{l}0.029 \\
(0.026)\end{array}$ & $\begin{array}{l}0.043 \\
(0.031)\end{array}$ & $\begin{array}{l}0.009 \\
(0.027)\end{array}$ & $\begin{array}{l}0.043 \\
(0.031)\end{array}$ & $\begin{array}{l}0.009 \\
(0.027)\end{array}$ \\
\hline Observations & 27,212 & 26,639 & 25,102 & 26,644 & 25,102 & 26,644 \\
\hline
\end{tabular}

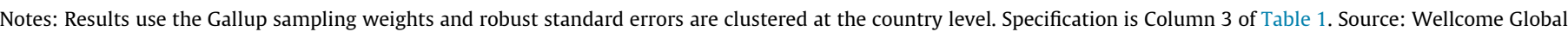
Monitor, 2018 and EM-DAT International Disaster Database, 1970-2017. * significant at 10\%; ${ }^{* *}$ significant at 5\%; ${ }^{* * *}$ significant at $1 \%$.

Table A12

Robutness to Excluding Potentially "Bad Controls"

\begin{tabular}{|c|c|c|c|c|c|c|}
\hline Outcome $\rightarrow$ & $\begin{array}{l}(1) \\
\text { Confidence } \\
\text { in scientists }\end{array}$ & $\begin{array}{l}(2) \\
\text { Scientists working for } \\
\text { private companies benefit } \\
\text { the public }\end{array}$ & $\begin{array}{l}\text { (3) } \\
\text { Scientists working for } \\
\text { private companies are } \\
\text { honest }\end{array}$ & $\begin{array}{l}\text { (4) } \\
\text { Scientists working for } \\
\text { universities benefit the } \\
\text { public }\end{array}$ & $\begin{array}{l}\text { (5) } \\
\text { Scientists working for } \\
\text { universities are } \\
\text { honest }\end{array}$ & $\begin{array}{l}(6) \\
\text { Scientists to find out } \\
\text { accurate } \\
\text { information }\end{array}$ \\
\hline $\begin{array}{l}\text { Exposure to } \\
\text { Epidemic } \\
(18-25)\end{array}$ & $-3.544^{* * *}$ & $-1.296^{* * *}$ & $-1.767^{* * *}$ & -0.703 & $-3.365^{* * *}$ & $-1.626^{* * *}$ \\
\hline Observations & $\begin{array}{l}(1.344) \\
83.014\end{array}$ & $\begin{array}{l}(0.337) \\
81,554\end{array}$ & $\begin{array}{l}(0.601) \\
76856\end{array}$ & $\begin{array}{l}(0.465) \\
81307\end{array}$ & $\begin{array}{l}(0.455) \\
76.123\end{array}$ & $\begin{array}{l}(0.616) \\
84104\end{array}$ \\
\hline Outcome $\rightarrow$ & $\begin{array}{l}(1) \\
\text { Have trust } \\
\text { in science }\end{array}$ & $\begin{array}{l}\text { (2) } \\
\text { Science and technology will } \\
\text { help improve life }\end{array}$ & $\begin{array}{l}\text { (3) } \\
\text { Studying diseases is a } \\
\text { part of science }\end{array}$ & $\begin{array}{l}(4) \\
\text { Have trust in doctors and } \\
\text { nurses }\end{array}$ & $\begin{array}{l}(5) \\
\text { Have trust in } \\
\text { hospitals and health } \\
\text { clinics }\end{array}$ & $\begin{array}{l}\text { (6) } \\
\text { Have trust in } \\
\text { traditional healers }\end{array}$ \\
\hline \multirow[t]{2}{*}{$\begin{array}{l}\text { Exposure to } \\
\text { Epidemic } \\
(18-25)\end{array}$} & 0.114 & 0.561 & 0.247 & 1.557 & 1.314 & -0.615 \\
\hline & $(0.402)$ & $(0.471)$ & $(0.446)$ & $(1.222)$ & (1.389) & $(0.545)$ \\
\hline Observations & 85,368 & 86,585 & 88,326 & 92,026 & 90,030 & 87,942 \\
\hline $\begin{array}{l}\text { Country fixed } \\
\text { effects }\end{array}$ & Yes & Yes & Yes & Yes & Yes & Yes \\
\hline $\begin{array}{l}\text { Cohort fixed } \\
\text { effects }\end{array}$ & Yes & Yes & Yes & Yes & Yes & Yes \\
\hline Male dummy & Yes & Yes & Yes & Yes & Yes & Yes \\
\hline $\begin{array}{l}\text { Country- } \\
\text { specific age } \\
\text { trends }\end{array}$ & Yes & Yes & Yes & Yes & Yes & Yes \\
\hline
\end{tabular}

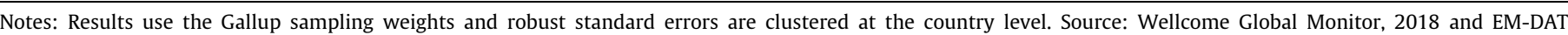
International Disaster Database, $1970-2017 .{ }^{*}$ significant at $10 \% ;{ }^{* *}$ significant at $5 \% ;{ }^{* * *}$ significant at $1 \%$. 
Table A13

Robutness to Controlling for the Number of Epidemic Experience.

\begin{tabular}{|c|c|c|c|c|c|c|}
\hline Outcome $\rightarrow$ & $\begin{array}{l}(1) \\
\text { Confidence } \\
\text { in scientists }\end{array}$ & $\begin{array}{l}(2) \\
\text { Scientists working for } \\
\text { private companies benefit } \\
\text { the public }\end{array}$ & $\begin{array}{l}\text { (3) } \\
\text { Scientists working for } \\
\text { private companies are } \\
\text { honest }\end{array}$ & $\begin{array}{l}\text { (4) } \\
\text { Scientists working for } \\
\text { universities benefit the } \\
\text { public }\end{array}$ & $\begin{array}{l}\text { (5) } \\
\text { Scientists working for } \\
\text { universities are } \\
\text { honest }\end{array}$ & $\begin{array}{l}(6) \\
\text { Scientists to find out } \\
\text { accurate } \\
\text { information }\end{array}$ \\
\hline \multirow[t]{2}{*}{$\begin{array}{l}\text { Exposure to } \\
\text { Epidemic } \\
(18-25)\end{array}$} & $-3.454^{* *}$ & $-1.283^{* * *}$ & $-1.731^{* * *}$ & -0.616 & $-3.330^{* * *}$ & $-1.438^{* *}$ \\
\hline & $(1.330)$ & $(0.338)$ & $(0.642)$ & $(0.478)$ & $(0.446)$ & $(0.664)$ \\
\hline \multirow[t]{2}{*}{$\begin{array}{l}\text { The number of } \\
\text { epidemics } \\
\text { exp. }\end{array}$} & $-0.193^{* * *}$ & $-0.178^{* * *}$ & $-0.146^{* * *}$ & $-0.189^{* * *}$ & $-0.223^{* * *}$ & $-0.297^{* * *}$ \\
\hline & $(0.007)$ & $(0.006)$ & $(0.006)$ & $(0.004)$ & $(0.006)$ & $(0.005)$ \\
\hline Observations & 82,854 & 81,406 & 76,723 & 81,147 & 75,992 & 83,939 \\
\hline
\end{tabular}

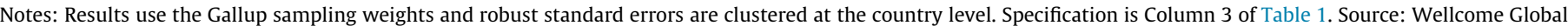
Monitor, 2018 and EM-DAT International Disaster Database, 1970-2017. * significant at 10\%; ${ }^{* *}$ significant at 5\%; *** significant at $1 \%$.

Table A14

Robustness to Excluding Most Affected Countries (i.e. excluding top 5 percentile).

\begin{tabular}{|c|c|c|c|c|c|c|}
\hline Outcome $\rightarrow$ & $\begin{array}{l}(1) \\
\text { Confidence } \\
\text { in scientists }\end{array}$ & $\begin{array}{l}\text { (2) } \\
\text { Scientists working for } \\
\text { private companies benefit } \\
\text { the public }\end{array}$ & $\begin{array}{l}\text { (3) } \\
\text { Scientists working for } \\
\text { private companies are } \\
\text { honest }\end{array}$ & $\begin{array}{l}\text { (4) } \\
\text { Scientists working for } \\
\text { universities benefit the } \\
\text { public }\end{array}$ & $\begin{array}{l}\text { (5) } \\
\text { Scientists working for } \\
\text { universities are } \\
\text { honest }\end{array}$ & $\begin{array}{l}\text { (6) } \\
\text { Scientists to find out } \\
\text { accurate } \\
\text { information }\end{array}$ \\
\hline \multirow[t]{2}{*}{$\begin{array}{l}\text { Exposure to } \\
\text { Epidemic } \\
(18-25)\end{array}$} & $-3.427^{* *}$ & $-1.326^{* * *}$ & $-1.965^{* * *}$ & -0.580 & $-3.269^{* * *}$ & $-1.413^{* *}$ \\
\hline & $(1.351)$ & $(0.313)$ & $(0.489)$ & $(0.463)$ & $(0.451)$ & $(0.667)$ \\
\hline \multirow[t]{2}{*}{ Observations } & 79,223 & 77,719 & 73,214 & 77,537 & 72,531 & 80,286 \\
\hline & (1) & (2) & (3) & (4) & (5) & (6) \\
\hline Outcome $\rightarrow$ & $\begin{array}{l}\text { Have trust } \\
\text { in science }\end{array}$ & $\begin{array}{l}\text { Science and technology will } \\
\text { help improve life }\end{array}$ & $\begin{array}{l}\text { Studying diseases is a } \\
\text { part of science }\end{array}$ & $\begin{array}{l}\text { Have trust in doctors and } \\
\text { nurses }\end{array}$ & $\begin{array}{l}\text { Have trust in } \\
\text { hospitals and health } \\
\text { clinics }\end{array}$ & $\begin{array}{l}\text { Have trust in } \\
\text { traditional healers }\end{array}$ \\
\hline \multirow{2}{*}{$\begin{array}{l}\text { Exposure to } \\
\text { Epidemic } \\
(18-25)\end{array}$} & 0.122 & 0.551 & 0.189 & 1.569 & 1.290 & -0.711 \\
\hline & $(0.468)$ & $(0.473)$ & $(0.364)$ & (1.235) & $(1.360)$ & $(0.528)$ \\
\hline Observations & 81,346 & 82,578 & 84,246 & 87,743 & 85,761 & 83,696 \\
\hline
\end{tabular}

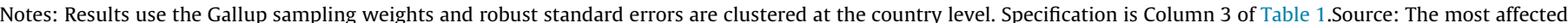

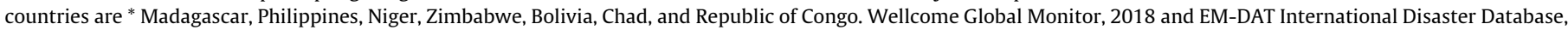
1970-2017. * significant at $10 \%$; ${ }^{* *}$ significant at $5 \%$; ${ }^{* * *}$ significant at $1 \%$.

Table A15

The Impact of Exposure to Epidemic (18-25) on Confidence in Scientists - Exploring the Role of Media.

\begin{tabular}{|c|c|c|c|c|c|c|}
\hline Outcome $\rightarrow$ & $\begin{array}{l}\text { (1) } \\
\text { Confidence } \\
\text { in scientists }\end{array}$ & $\begin{array}{l}(2) \\
\text { Scientists working for } \\
\text { private companies benefit } \\
\text { the public }\end{array}$ & $\begin{array}{l}\text { (3) } \\
\text { Scientists working for } \\
\text { private companies are } \\
\text { honest }\end{array}$ & $\begin{array}{l}\text { (4) } \\
\text { Scientists working for } \\
\text { universities benefit the } \\
\text { public }\end{array}$ & $\begin{array}{l}\text { (5) } \\
\text { Scientists working } \\
\text { for universities are } \\
\text { honest }\end{array}$ & $\begin{array}{l}(6) \\
\text { Scientists to find } \\
\text { out accurate } \\
\text { information }\end{array}$ \\
\hline \multirow[t]{2}{*}{$\begin{array}{l}\text { Exposure to Epidemic } \\
\quad(18-25)\end{array}$} & $-14.230^{* *}$ & $-8.094^{* * *}$ & $-20.589^{* * *}$ & -8.239 & $-22.039^{* *}$ & -3.383 \\
\hline & $(7.009)$ & $(2.589)$ & $(5.054)$ & $(5.618)$ & $(8.671)$ & $(6.349)$ \\
\hline \multirow[t]{2}{*}{$\begin{array}{l}\text { Exposure to Epidemic } \\
(18-25)^{*} \text { TV Per Capita } \\
(18-25)\end{array}$} & -0.002 & 0.001 & -0.000 & 0.000 & -0.002 & -0.001 \\
\hline & $(0.001)$ & $(0.001)$ & $(0.001)$ & $(0.001)$ & $(0.002)$ & $(0.001)$ \\
\hline \multirow[t]{2}{*}{$\begin{array}{l}\text { Exposure to Epidemic } \\
(18-25)^{*} \text { Radio Per } \\
\text { Capita }(18-25)\end{array}$} & 0.012 & 0.001 & 0.007 & -0.000 & 0.013 & 0.004 \\
\hline & $(0.009)$ & $(0.003)$ & $(0.006)$ & $(0.005)$ & $(0.011)$ & $(0.008)$ \\
\hline TV Per Capita (18-25) & $\begin{array}{l}-0.000 \\
(0.000)\end{array}$ & $\begin{array}{l}-0.000 \\
(0.000)\end{array}$ & $\begin{array}{l}0.000 \\
(0.000)\end{array}$ & $\begin{array}{l}0.000 \\
(0.000)\end{array}$ & $\begin{array}{l}-0.000 \\
(0.000)\end{array}$ & $\begin{array}{l}0.000 \\
(0.000)\end{array}$ \\
\hline Radio Per Capita (18-25) & $\begin{array}{l}-0.000 \\
(0.000)\end{array}$ & $\begin{array}{l}-0.000 \\
(0.000)\end{array}$ & $\begin{array}{l}0.000 \\
(0.000)\end{array}$ & $\begin{array}{l}-0.000^{* * *} \\
(0.000)\end{array}$ & $\begin{array}{l}0.000 \\
(0.000)\end{array}$ & $\begin{array}{l}-0.000 \\
(0.000)\end{array}$ \\
\hline Observations & 28,085 & 27,889 & 26,453 & 27,746 & 26,150 & 28,471 \\
\hline
\end{tabular}

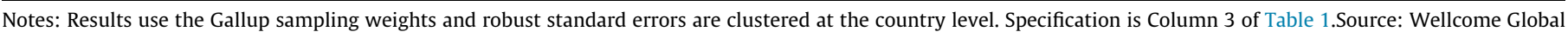
Monitor, 2018 and EM-DAT International Disaster Database, 1970-2017. * significant at 10\%; ${ }^{* *}$ significant at 5\%; ${ }^{* * *}$ significant at 1\%. 
Table A16

Robutness to Ordered Logit Estimation.

\begin{tabular}{|c|c|c|c|c|c|c|}
\hline Outcome $\rightarrow$ & $\begin{array}{l}(1) \\
\text { Confidence } \\
\text { in scientists }\end{array}$ & $\begin{array}{l}(2) \\
\text { Scientists working for } \\
\text { private companies benefit } \\
\text { the public }\end{array}$ & $\begin{array}{l}\text { (3) } \\
\text { Scientists working for } \\
\text { private companies are } \\
\text { honest }\end{array}$ & $\begin{array}{l}\text { (4) } \\
\text { Scientists working for } \\
\text { universities benefit the } \\
\text { public }\end{array}$ & $\begin{array}{l}\text { (5) } \\
\text { Scientists working } \\
\text { for universities are } \\
\text { honest }\end{array}$ & $\begin{array}{l}\text { (6) } \\
\text { Scientists to find } \\
\text { out accurate } \\
\text { information }\end{array}$ \\
\hline \multirow{2}{*}{$\begin{array}{l}\text { Exposure to Epidemic } \\
\quad(18-25)\end{array}$} & $22300^{* * *}$ & $66.00^{* * *}$ & $301.81^{* * *}$ & $104.13^{*}$ & $2646.74^{* * *}$ & $92.46^{* * *}$ \\
\hline & $(95100)$ & $(92.37)$ & $(520.52)$ & $(278.16)$ & (5196.73) & $(416.19)$ \\
\hline \multirow[t]{2}{*}{ Observations } & 82,854 & 81,406 & 76,723 & 81,147 & 75,792 & 83,939 \\
\hline & (1) & $(2)$ & (3) & $(4)$ & (5) & $(6)$ \\
\hline Outcome $\rightarrow$ & $\begin{array}{l}\text { Have trust } \\
\text { in science }\end{array}$ & $\begin{array}{l}\text { Science and technology } \\
\text { will help improve life }\end{array}$ & $\begin{array}{l}\text { Studying diseases is a } \\
\text { part of science }\end{array}$ & $\begin{array}{l}\text { Have trust in doctors } \\
\text { and nurses }\end{array}$ & $\begin{array}{l}\text { Have trust in } \\
\text { hospitals and health } \\
\text { clinics }\end{array}$ & $\begin{array}{l}\text { Have trust in } \\
\text { traditional healers }\end{array}$ \\
\hline \multirow{2}{*}{$\begin{array}{l}\text { Exposure to Epidemic } \\
\qquad(18-25)\end{array}$} & 2.050 & 0.002 & 0.023 & 0.011 & 0.000 & 0.770 \\
\hline & $(6.791)$ & $(0.010)$ & $(0.090)$ & $(0.062)$ & $(0.042)$ & $(6.013)$ \\
\hline Observations & 85,199 & 86,397 & 88,138 & 91,835 & 89,851 & 87,761 \\
\hline Country fixed effects & Yes & Yes & Yes & Yes & Yes & Yes \\
\hline Cohort fixed effects & Yes & Yes & Yes & Yes & Yes & Yes \\
\hline Male dummy & Yes & Yes & Yes & Yes & Yes & Yes \\
\hline $\begin{array}{l}\text { Country-specific age } \\
\text { trends }\end{array}$ & Yes & Yes & Yes & Yes & Yes & Yes \\
\hline
\end{tabular}

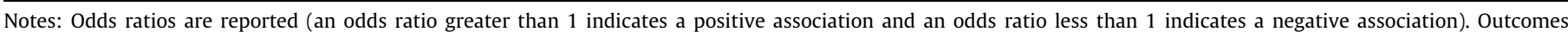

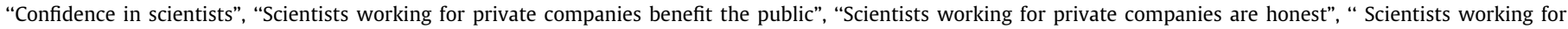

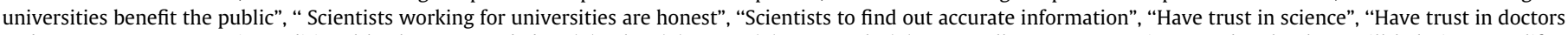

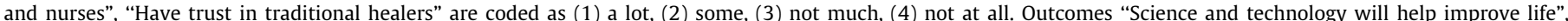

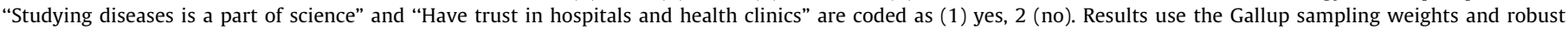

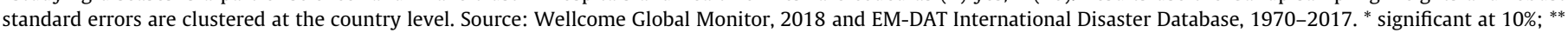
significant at $5 \%$; ${ }^{* * *}$ significant at $1 \%$.

Table A17

Robutness to Multinomial Logit Estimation.

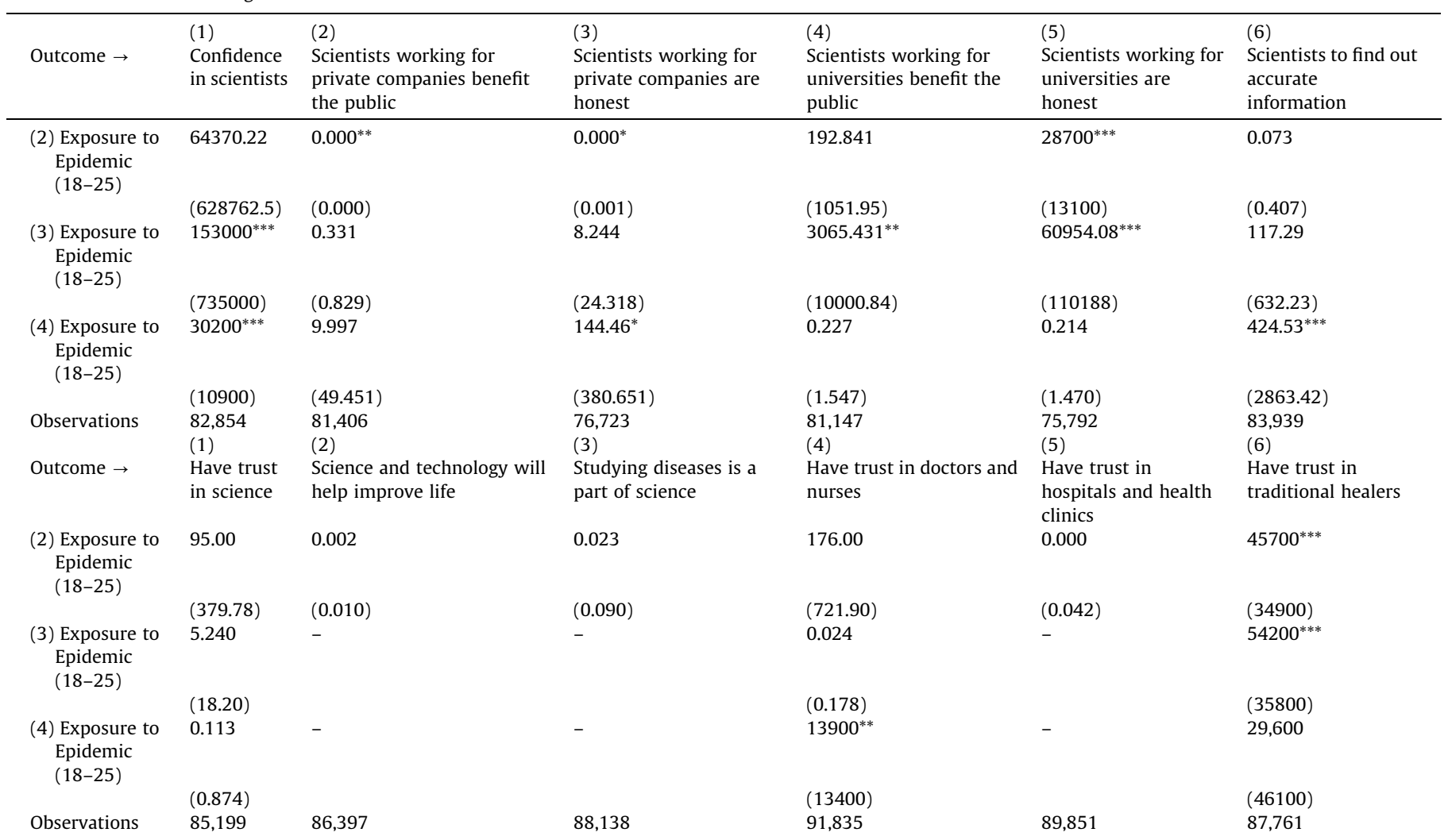

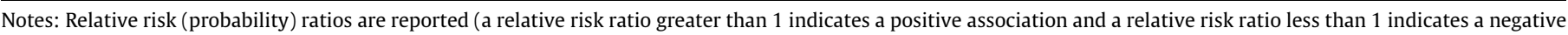

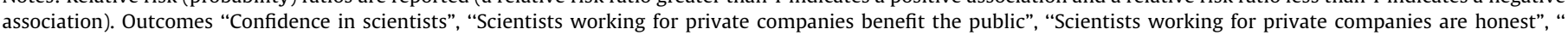

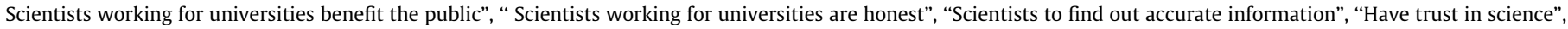

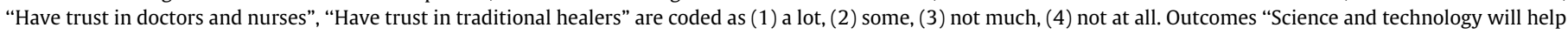

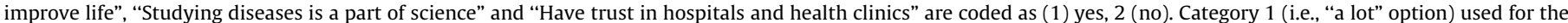

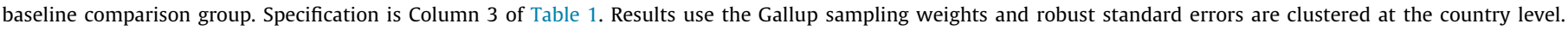
Source: Wellcome Global Monitor, 2018 and EM-DAT International Disaster Database, 1970-2017. ${ }^{*}$ significant at $10 \%$; ${ }^{* *}$ significant at 5\%; ${ }^{* * *}$ significant at 1\%. 
Table A18

Full List of Epidemics from the EM-DAT Database.

\begin{tabular}{|c|c|c|c|c|}
\hline Country & Year & Epidemic & Total no of affected people & Total no of deaths \\
\hline Afghanistan & 1998 & cholera & 15,783 & 185 \\
\hline Afghanistan & 1999 & cholera & 20,702 & 135 \\
\hline Afghanistan & 2000 & cholera & 2228 & 50 \\
\hline Afghanistan & 2001 & cholera & 4425 & 154 \\
\hline Afghanistan & 2002 & leishmaniasis & 206,834 & 102 \\
\hline Afghanistan & 2005 & cholera & 3245 & 0 \\
\hline Afghanistan & 2008 & cholera & 1100 & 17 \\
\hline Albania & 1996 & poliovirus & 66 & 7 \\
\hline Albania & 2002 & unknown & 226 & 0 \\
\hline Algeria & 1991 & typhiod & 204 & 0 \\
\hline Algeria & 1997 & typhiod & 364 & 1 \\
\hline Angola & 1987 & cholera & 673 & 59 \\
\hline Angola & 1989 & cholera & 15,525 & 766 \\
\hline Angola & 1995 & meningitis & 1007 & 0 \\
\hline Angola & 1998 & meningitis & 1113 & 115 \\
\hline Angola & 1999 & poliovirus & 873 & 188 \\
\hline Angola & 2000 & meningitis & 117 & 18 \\
\hline Angola & 2001 & meningitis & 420 & 39 \\
\hline Angola & 2004 & marburg virus & 45 & 329 \\
\hline Angola & 2006 & cholera & 57,570 & 2354 \\
\hline Angola & 2007 & cholera & 18,343 & 515 \\
\hline Angola & 2008 & cholera & 17,437 & 363 \\
\hline Angola & 2009 & diarrhoeal syndrome & 25,938 & 116 \\
\hline Angola & 2015 & yellow fever & 4599 & 384 \\
\hline Angola & 2018 & cholera & 139 & 2 \\
\hline Argentina & 1992 & cholera & 3883 & 67 \\
\hline Argentina & 2009 & dengue and dengue haemorrhagic fever & 13,366 & 6 \\
\hline Australia & 2002 & sars & 6 & 0 \\
\hline Australia & 2016 & dengue and dengue haemorrhagic fever & 2016 & 0 \\
\hline Bangladesh & 1977 & cholera & 10,461 & 260 \\
\hline Bangladesh & 1982 & cholera & 173,460 & 2696 \\
\hline Bangladesh & 1986 & water-borne diseases & 52,000 & 165 \\
\hline Bangladesh & 1987 & & 601,200 & 750 \\
\hline Bangladesh & 1991 & & $1,608,000$ & 2700 \\
\hline Bangladesh & 1993 & & 5660 & 38 \\
\hline Bangladesh & 1995 & & 21,236 & 400 \\
\hline Bangladesh & 1996 & & 10,000 & 20 \\
\hline Bangladesh & 1997 & & 14,330 & 64 \\
\hline Bangladesh & 1998 & & 185,000 & 151 \\
\hline Bangladesh & 2000 & & 26,214 & 31 \\
\hline Bangladesh & 2002 & & 49,904 & 96 \\
\hline Bangladesh & 2004 & nipah viral disease & 54 & 32 \\
\hline Bangladesh & 2007 & cholera & 284,910 & 86 \\
\hline Bangladesh & 2017 & diphteria & 789 & 15 \\
\hline Belarus & 1995 & & 282 & 13 \\
\hline Belarus & 1997 & & 605 & 0 \\
\hline Belgium & 1945 & poliovirus & 104 & 0 \\
\hline Benin & 1976 & poliovirus & 7 & 1 \\
\hline Benin & 1987 & & 403 & 65 \\
\hline Benin & 1989 & & 2411 & 228 \\
\hline Benin & 1996 & yellow fever & 21 & 65 \\
\hline Benin & 1997 & & 226 & 47 \\
\hline Benin & 1998 & & 527 & 78 \\
\hline Benin & 1999 & diarrhoeal syndrome & 241 & 9 \\
\hline Benin & 2000 & meningitis & 7762 & 351 \\
\hline Benin & 2001 & meningitis & 9760 & 378 \\
\hline Benin & 2002 & & 452 & 50 \\
\hline Benin & 2003 & cholera & 265 & 3 \\
\hline Benin & 2005 & cholera & 206 & 4 \\
\hline Benin & 2008 & cholera & 988 & 33 \\
\hline Benin & 2010 & cholera & 1037 & 25 \\
\hline Benin & 2013 & cholera & 486 & 6 \\
\hline Benin & 2016 & cholera & 678 & 13 \\
\hline Benin & 2019 & meningitis & 24 & 13 \\
\hline Bhutan & 1985 & & 247 & 41 \\
\hline Bhutan & 1992 & cholera & 494 & 0 \\
\hline Bolivia & 1969 & poliovirus & 77 & 18 \\
\hline Bolivia & 1989 & yellow fever & 97 & 67 \\
\hline Bolivia & 1991 & cholera & 17,665 & 329 \\
\hline Bolivia & 1997 & cholera & 734 & 18 \\
\hline Bolivia & 1998 & cholera & 165 & 5 \\
\hline Bolivia & 1999 & yellow fever & 68 & 33 \\
\hline Bolivia & 2007 & dengue and dengue haemorrhagic fever & 228 & 1 \\
\hline Bolivia & 2008 & dengue and dengue haemorrhagic fever & 7202 & 27 \\
\hline
\end{tabular}


Table A18 (continued)

\begin{tabular}{|c|c|c|c|c|}
\hline Country & Year & Epidemic & Total no of affected people & Total no of deaths \\
\hline Bolivia & 2010 & dengue and dengue haemorrhagic fever & 25,236 & 29 \\
\hline Bolivia & 2018 & h1n1 & 1428 & 23 \\
\hline Bosnia and Herzegovina & 2000 & hepatitis a & 400 & 0 \\
\hline Botswana & 1988 & & 14,618 & 183 \\
\hline Botswana & 2006 & diarrhoeal syndrome & 22,264 & 470 \\
\hline Botswana & 2008 & cholera & 15 & 2 \\
\hline Brazil & 1974 & & 30,000 & 1500 \\
\hline Brazil & 1975 & & 107 & 0 \\
\hline Brazil & 1986 & dengue and dengue haemorrhagic fever & 34,722 & 0 \\
\hline Brazil & 1988 & & 170 & 0 \\
\hline Brazil & 1991 & cholera & 15,240 & 196 \\
\hline Brazil & 1995 & dengue and dengue haemorrhagic fever & 112,939 & 2 \\
\hline Brazil & 1997 & & 25,900 & 0 \\
\hline Brazil & 1998 & dengue and dengue haemorrhagic fever & 214,340 & 13 \\
\hline Brazil & 1999 & cholera & 235 & 3 \\
\hline Brazil & 2002 & dengue and dengue haemorrhagic fever & 317,730 & 57 \\
\hline Brazil & 2008 & dengue and dengue haemorrhagic fever & 162,701 & 123 \\
\hline Brazil & 2009 & dengue and dengue haemorrhagic fever & 126,139 & 23 \\
\hline Brazil & 2010 & dengue and dengue haemorrhagic fever & 942,153 & 0 \\
\hline Brazil & 2016 & yellow fever & 777 & 261 \\
\hline Brazil & 2017 & yellow fever & 310 & 154 \\
\hline Burkina Faso & 1969 & meningitis & 4550 & 304 \\
\hline Burkina Faso & 1979 & & 1612 & 241 \\
\hline Burkina Faso & 1981 & & 10,013 & 1091 \\
\hline Burkina Faso & 1983 & yellow fever & 386 & 237 \\
\hline Burkina Faso & 1984 & & 1000 & 0 \\
\hline Burkina Faso & 1996 & & 40,967 & 4135 \\
\hline Burkina Faso & 1997 & & 17,996 & 2274 \\
\hline Burkina Faso & 1998 & cholera & 441 & 26 \\
\hline Burkina Faso & 2001 & meningitis & 20,820 & 2978 \\
\hline Burkina Faso & 2003 & meningitis & 7146 & 1058 \\
\hline Burkina Faso & 2004 & meningitis & 2783 & 527 \\
\hline Burkina Faso & 2005 & cholera & 606 & 9 \\
\hline Burkina Faso & 2006 & meningitis & 7402 & 784 \\
\hline Burkina Faso & 2007 & meningitis & 20,765 & 1490 \\
\hline Burkina Faso & 2008 & measles & 53,000 & 550 \\
\hline Burkina Faso & 2009 & meningitis & 2892 & 389 \\
\hline Burkina Faso & 2010 & meningitis & 5960 & 841 \\
\hline Burkina Faso & 2017 & dengue and dengue haemorrhagic fever & 9029 & 18 \\
\hline Burundi & 1978 & cholera & 1530 & 54 \\
\hline Burundi & 1992 & & 2068 & 220 \\
\hline Burundi & 1997 & typhus & 24,350 & 21 \\
\hline Burundi & 1999 & & 616,434 & 80 \\
\hline Burundi & 2000 & & 730,691 & 308 \\
\hline Burundi & 2002 & & 2163 & 87 \\
\hline Burundi & 2003 & cholera & 230 & 6 \\
\hline Burundi & 2011 & cholera & 600 & 12 \\
\hline Burundi & 2016 & cholera & 193 & 1 \\
\hline Cabo Verde & 1994 & cholera & 12,344 & 245 \\
\hline Cabo Verde & 2009 & dengue and dengue haemorrhagic fever & 20,147 & 6 \\
\hline Cambodia & 1992 & & 380,400 & 50 \\
\hline Cambodia & 1997 & dengue and dengue haemorrhagic fever & 227 & 3 \\
\hline Cambodia & 1998 & dengue and dengue haemorrhagic fever & 15,069 & 490 \\
\hline Cambodia & 1999 & cholera & 874 & 56 \\
\hline Cambodia & 2006 & dengue and dengue haemorrhagic fever & 4368 & 0 \\
\hline Cambodia & 2007 & dengue and dengue haemorrhagic fever & 17,000 & 182 \\
\hline Cameroon & 1988 & & 340 & 39 \\
\hline Cameroon & 1989 & & 550 & 100 \\
\hline Cameroon & 1990 & yellow fever & 172 & 118 \\
\hline Cameroon & 1991 & cholera & 1343 & 308 \\
\hline Cameroon & 1992 & & 7865 & 731 \\
\hline Cameroon & 1993 & & 4070 & 513 \\
\hline Cameroon & 1996 & cholera & 2825 & 378 \\
\hline Cameroon & 1997 & shigellosis & 479 & 109 \\
\hline Cameroon & 1998 & cholera & 2086 & 239 \\
\hline Cameroon & 1999 & & 105 & 14 \\
\hline Cameroon & 2000 & meningitis & 65 & 22 \\
\hline Cameroon & 2001 & meningitis & 542 & 31 \\
\hline Cameroon & 2004 & cholera & 2924 & 46 \\
\hline Cameroon & 2005 & cholera & 1400 & 42 \\
\hline Cameroon & 2006 & cholera & 71 & 8 \\
\hline Cameroon & 2009 & cholera & 1456 & 109 \\
\hline Cameroon & 2010 & cholera & 7869 & 515 \\
\hline Cameroon & 2011 & cholera & 16,706 & 639 \\
\hline Cameroon & 2014 & cholera & 2056 & 111 \\
\hline
\end{tabular}


Table A18 (continued)

\begin{tabular}{|c|c|c|c|c|}
\hline Country & Year & Epidemic & Total no of affected people & Total no of deaths \\
\hline Cameroon & 2015 & measles & 858 & 0 \\
\hline Cameroon & 2018 & cholera & 942 & 57 \\
\hline Canada & 1918 & h1n1 & $2,000,000$ & 50,000 \\
\hline Canada & 1953 & poliovirus & 8000 & 481 \\
\hline Canada & 1991 & & 171 & 18 \\
\hline Canada & 2001 & cryptosporidiosis & 399 & 1 \\
\hline Canada & 2002 & sars & 347 & 45 \\
\hline Central African Republic & 1992 & & 418 & 56 \\
\hline Central African Republic & 1999 & & 86 & 14 \\
\hline Central African Republic & 2000 & & 2572 & 448 \\
\hline Central African Republic & 2001 & meningitis & 1473 & 343 \\
\hline Central African Republic & 2002 & hepatitis e & 727 & 6 \\
\hline Central African Republic & 2003 & shigellosis & 379 & 23 \\
\hline Central African Republic & 2011 & cholera & 172 & 16 \\
\hline Central African Republic & 2013 & measles & 63 & 0 \\
\hline Central African Republic & 2016 & cholera & 266 & 21 \\
\hline Central African Republic & 2018 & hepatitis e & 119 & 1 \\
\hline Central African Republic & 2019 & measles & 3600 & 53 \\
\hline Chad & 1971 & cholera & 7476 & 2312 \\
\hline Chad & 1988 & & 6794 & 433 \\
\hline Chad & 1991 & cholera & 12,204 & 1262 \\
\hline Chad & 1996 & cholera & 1317 & 94 \\
\hline Chad & 1997 & & 2835 & 239 \\
\hline Chad & 2000 & meningitis & 9673 & 1209 \\
\hline Chad & 2001 & cholera & 3444 & 113 \\
\hline Chad & 2003 & cholera & 131 & 11 \\
\hline Chad & 2004 & cholera & 3567 & 144 \\
\hline Chad & 2005 & & 6000 & 115 \\
\hline Chad & 2006 & cholera & 216 & 20 \\
\hline Chad & 2008 & hepatitis e & 1755 & 22 \\
\hline Chad & 2009 & meningitis & 871 & 102 \\
\hline Chad & 2010 & measles & 5319 & 239 \\
\hline Chad & 2011 & cholera & 18,123 & 557 \\
\hline Chad & 2012 & meningitis & 1708 & 88 \\
\hline Chad & 2017 & cholera & 652 & 58 \\
\hline Chad & 2018 & measles & 4227 & 90 \\
\hline Chile & 1991 & cholera & 40 & 1 \\
\hline China & 1987 & rotavirus & 1000 & 0 \\
\hline China & 1988 & & 2000 & 0 \\
\hline China & 2002 & sars & 6652 & 369 \\
\hline China & 2004 & h5n1 & 9 & 16 \\
\hline China & 2005 & septicaemia & 168 & 38 \\
\hline Colombia & 1991 & cholera & 14,137 & 350 \\
\hline Colombia & 1996 & cholera & 3000 & 62 \\
\hline Colombia & 2012 & dengue and dengue haemorrhagic fever & 23,235 & 0 \\
\hline Colombia & 2013 & dengue and dengue haemorrhagic fever & 1171 & 91 \\
\hline Colombia & 2016 & yellow fever & 12 & 0 \\
\hline Colombia & 2019 & dengue and dengue haemorrhagic fever & 79,639 & 169 \\
\hline Comoros (the) & 1989 & typhiod & 450 & 3 \\
\hline Comoros (the) & 1998 & cholera & 3200 & 40 \\
\hline Comoros (the) & 1999 & cholera & 140 & 14 \\
\hline Comoros (the) & 2005 & chikungunya & 2282 & 0 \\
\hline Comoros (the) & 2007 & cholera & 1490 & 29 \\
\hline Congo (the Dem.Rep.) & 1976 & ebola & 262 & 245 \\
\hline Congo (the Dem.Rep.) & 1996 & cholera & 1954 & 202 \\
\hline Congo (the Dem.Rep.) & 1997 & cholera & 1411 & 54 \\
\hline Congo (the Dem.Rep.) & 1998 & cholera & 13,884 & 972 \\
\hline Congo (the Dem.Rep.) & 1999 & marburg virus & 72 & 3 \\
\hline Congo (the Dem.Rep.) & 2000 & & 63 & 26 \\
\hline Congo (the Dem.Rep.) & 2001 & cholera & 11,094 & 838 \\
\hline Congo (the Dem.Rep.) & 2002 & h1n1 & 539,375 & 2502 \\
\hline Congo (the Dem.Rep.) & 2003 & cholera & 20,401 & 786 \\
\hline Congo (the Dem.Rep.) & 2004 & typhiod & 46,220 & 406 \\
\hline Congo (the Dem.Rep.) & 2005 & cholera & 4872 & 101 \\
\hline Congo (the Dem.Rep.) & 2006 & cholera & 2986 & 151 \\
\hline Congo (the Dem.Rep.) & 2007 & ebola & 419 & 172 \\
\hline Congo (the Dem.Rep.) & 2009 & cholera & 15,909 & 209 \\
\hline Congo (the Dem.Rep.) & 2010 & cholera & 4342 & 56 \\
\hline Congo (the Dem.Rep.) & 2011 & cholera & 28,757 & 636 \\
\hline Congo (the Dem.Rep.) & 2012 & cholera & 23,626 & 608 \\
\hline Congo (the Dem.Rep.) & 2014 & ebola & 17 & 49 \\
\hline Congo (the Dem.Rep.) & 2016 & measles & 2638 & 55 \\
\hline Congo (the Dem.Rep.) & 2017 & cholera & 1022 & 43 \\
\hline Congo (the Dem.Rep.) & 2018 & ebola & 3454 & 2297 \\
\hline Congo (the Dem.Rep.) & 2019 & measles & 277,000 & 5872 \\
\hline
\end{tabular}


Table A18 (continued)

\begin{tabular}{|c|c|c|c|c|}
\hline Country & Year & Epidemic & Total no of affected people & Total no of deaths \\
\hline Congo (the) & 1997 & cholera & 485 & 83 \\
\hline Congo (the) & 1999 & cholera & 99 & 15 \\
\hline Congo (the) & 2001 & ebola & 13 & 19 \\
\hline Congo (the) & 2002 & ebola & 15 & 128 \\
\hline Congo (the) & 2003 & ebola & 2 & 29 \\
\hline Congo (the) & 2005 & ebola & 2 & 10 \\
\hline Congo (the) & 2006 & cholera & 3030 & 50 \\
\hline Congo (the) & 2008 & cholera & 630 & 26 \\
\hline Congo (the) & 2010 & poliovirus & 524 & 219 \\
\hline Congo (the) & 2011 & chikungunya & 10,819 & 65 \\
\hline Congo (the) & 2012 & & 57 & 5 \\
\hline Congo (the) & 2013 & cholera & 1071 & 16 \\
\hline Congo (the) & 2019 & measles & 208,246 & 3819 \\
\hline Costa Rica & 1995 & dengue and dengue haemorrhagic fever & 4786 & 0 \\
\hline Costa Rica & 2013 & dengue and dengue haemorrhagic fever & 12,000 & 3 \\
\hline Costa Rica & 2019 & dengue and dengue haemorrhagic fever & 4852 & 0 \\
\hline Cuba & 1993 & neuromyelopathy & 49,358 & 0 \\
\hline Cuba & 1997 & dengue and dengue haemorrhagic fever & 823 & 3 \\
\hline Cyprus & 1996 & meningitis & 280 & 0 \\
\hline Côte d'Ivoire & 1970 & cholera & 1500 & 120 \\
\hline Côte d'Ivoire & 1991 & cholera & 50 & 16 \\
\hline Côte d'Ivoire & 1995 & cholera & 2027 & 150 \\
\hline Côte d'Ivoire & 2001 & cholera & 3180 & 196 \\
\hline Côte d'Ivoire & 2002 & cholera & 861 & 77 \\
\hline Côte d'Ivoire & 2005 & & 210 & 40 \\
\hline Côte d'Ivoire & 2006 & cholera & 451 & 42 \\
\hline Côte d'Ivoire & 2007 & meningitis & 150 & 30 \\
\hline Côte d'Ivoire & 2017 & dengue and dengue haemorrhagic fever & 621 & 2 \\
\hline Djibouti & 1994 & cholera & 239 & 10 \\
\hline Djibouti & 1997 & cholera & 827 & 29 \\
\hline Djibouti & 1998 & & 2000 & 43 \\
\hline Djibouti & 2000 & cholera & 419 & 4 \\
\hline Djibouti & 2007 & cholera & 562 & 6 \\
\hline Dominican Republic (the) & 1995 & dengue and dengue haemorrhagic fever & 1252 & 2 \\
\hline Dominican Republic (the) & 2009 & dengue and dengue haemorrhagic fever & 3270 & 25 \\
\hline Dominican Republic (the) & 2010 & cholera & 17,321 & 130 \\
\hline Dominican Republic (the) & 2011 & cholera & 220 & 1 \\
\hline Dominican Republic (the) & 2012 & cholera & 26,090 & 167 \\
\hline Dominican Republic (the) & 2019 & dengue and dengue haemorrhagic fever & 16,907 & 34 \\
\hline Ecuador & 1967 & poliovirus & 528 & 36 \\
\hline Ecuador & 1969 & encephalitis syndrome (aes) & 40,000 & 400 \\
\hline Ecuador & 1977 & typhiod & 300 & 0 \\
\hline Ecuador & 1991 & cholera & 15,131 & 343 \\
\hline Ecuador & 1995 & dengue and dengue haemorrhagic fever & 3399 & 0 \\
\hline Ecuador & 1998 & cholera & 11 & 1 \\
\hline Ecuador & 2000 & & 100,220 & 8 \\
\hline Ecuador & 2002 & unknown & 100 & 0 \\
\hline Ecuador & 2010 & dengue and dengue haemorrhagic fever & 4000 & 4 \\
\hline Ecuador & 2012 & dengue and dengue haemorrhagic fever & 6967 & 11 \\
\hline Egypt & 2004 & hepatitis a & 143 & 15 \\
\hline El Salvador & 1969 & encephalitis syndrome (aes) & 19 & 12 \\
\hline El Salvador & 1991 & cholera & 5625 & 155 \\
\hline El Salvador & 1992 & cholera & 350 & 0 \\
\hline El Salvador & 1995 & dengue and dengue haemorrhagic fever & 9296 & 5 \\
\hline El Salvador & 1998 & dengue and dengue haemorrhagic fever & 1670 & 0 \\
\hline El Salvador & 2000 & dengue and dengue haemorrhagic fever & 211 & 24 \\
\hline El Salvador & 2002 & dengue and dengue haemorrhagic fever & 2399 & 6 \\
\hline El Salvador & 2003 & pneumonia & 50,000 & 304 \\
\hline El Salvador & 2009 & dengue and dengue haemorrhagic fever & 4598 & 7 \\
\hline El Salvador & 2014 & dengue and dengue haemorrhagic fever & 12,783 & 4 \\
\hline El Salvador & 2019 & dengue and dengue haemorrhagic fever & 16,573 & 5 \\
\hline Equatorial Guinea & 2004 & & 946 & 15 \\
\hline Ethiopia & 1970 & cholera & 4000 & 500 \\
\hline Ethiopia & 1980 & dysentery & 25,000 & 157 \\
\hline Ethiopia & 1981 & & 50,000 & 990 \\
\hline Ethiopia & 1985 & cholera & 4815 & 1101 \\
\hline Ethiopia & 1988 & & 41,304 & 7400 \\
\hline Ethiopia & 1999 & & 276 & 9 \\
\hline Ethiopia & 2000 & meningitis & 7033 & 371 \\
\hline Ethiopia & 2001 & meningitis & 8166 & 429 \\
\hline Ethiopia & 2005 & & 964 & 74 \\
\hline Ethiopia & 2006 & diarrhoeal syndrome & 32,848 & 351 \\
\hline Ethiopia & 2008 & diarrhoeal syndrome & 3134 & 20 \\
\hline Ethiopia & 2009 & cholera & 13,652 & 135 \\
\hline Ethiopia & 2010 & diarrhoeal syndrome & 967 & 16 \\
\hline
\end{tabular}


Table A18 (continued)

\begin{tabular}{|c|c|c|c|c|}
\hline Country & Year & Epidemic & Total no of affected people & Total no of deaths \\
\hline Ethiopia & 2013 & yellow fever & 288 & 110 \\
\hline Ethiopia & 2018 & measles & 4000 & 0 \\
\hline Ethiopia & 2019 & cholera & 1916 & 39 \\
\hline Fiji & 2019 & measles & 14 & 0 \\
\hline France & 2002 & sars & 6 & 1 \\
\hline Gabon & 1988 & cholera & 132 & 0 \\
\hline Gabon & 1996 & ebola & 15 & 45 \\
\hline Gabon & 2001 & ebola & 10 & 50 \\
\hline Gabon & 2004 & typhiod & 100 & 1 \\
\hline Gabon & 2007 & chikungunya & 17,900 & 0 \\
\hline Gabon & 2010 & chikungunya & 551 & 0 \\
\hline Gambia (the) & 1997 & & 793 & 120 \\
\hline Gambia (the) & 2000 & meningitis & 116 & 21 \\
\hline Germany & 2002 & & 609 & 0 \\
\hline Ghana & 1977 & cholera & 6558 & 0 \\
\hline Ghana & 1984 & & 1500 & 103 \\
\hline Ghana & 1988 & & 138 & 15 \\
\hline Ghana & 1989 & & 19 & 0 \\
\hline Ghana & 1996 & & 3757 & 411 \\
\hline Ghana & 1997 & & 159 & 26 \\
\hline Ghana & 1998 & cholera & 1546 & 67 \\
\hline Ghana & 1999 & diarrhoeal syndrome & 1196 & 24 \\
\hline Ghana & 2001 & & 1141 & 12 \\
\hline Ghana & 2005 & cholera & 2248 & 40 \\
\hline Ghana & 2010 & meningitis & 100 & 27 \\
\hline Ghana & 2011 & cholera & 10,002 & 101 \\
\hline Ghana & 2012 & cholera & 5441 & 76 \\
\hline Ghana & 2013 & cholera & 560 & 18 \\
\hline Ghana & 2014 & cholera & 56,469 & 249 \\
\hline Ghana & 2015 & meningitis & 465 & 85 \\
\hline Ghana & 2016 & cholera & 172 & 0 \\
\hline Guatemala & 1969 & encephalitis syndrome (aes) & 8 & 4 \\
\hline Guatemala & 1991 & cholera & 26,800 & 180 \\
\hline Guatemala & 1995 & dengue and dengue haemorrhagic fever & 3402 & 0 \\
\hline Guatemala & 1998 & cholera & 1345 & 17 \\
\hline Guatemala & 2002 & dengue and dengue haemorrhagic fever & 2042 & 1 \\
\hline Guatemala & 2013 & dengue and dengue haemorrhagic fever & 1977 & 8 \\
\hline Guatemala & 2015 & chikungunya & 15,211 & 0 \\
\hline Guatemala & 2019 & dengue and dengue haemorrhagic fever & 6264 & 17 \\
\hline Guinea & 1987 & & 30 & 18 \\
\hline Guinea & 1999 & cholera & 123 & 12 \\
\hline Guinea & 2000 & yellow fever & 322 & 190 \\
\hline Guinea & 2001 & cholera & 143 & 12 \\
\hline Guinea & 2002 & & 123 & 23 \\
\hline Guinea & 2003 & yellow fever & 43 & 24 \\
\hline Guinea & 2006 & cholera & 298 & 129 \\
\hline Guinea & 2007 & cholera & 2410 & 90 \\
\hline Guinea & 2012 & cholera & 5523 & 105 \\
\hline Guinea & 2013 & measles & 143 & 0 \\
\hline Guinea & 2014 & ebola & 3814 & 2544 \\
\hline Guinea & 2017 & measles & 122 & 0 \\
\hline Guinea-Bissau & 1987 & cholera & 6000 & 68 \\
\hline Guinea-Bissau & 1996 & cholera & 26,967 & 961 \\
\hline Guinea-Bissau & 1997 & cholera & 22,299 & 781 \\
\hline Guinea-Bissau & 1999 & & 2169 & 404 \\
\hline Guinea-Bissau & 2008 & cholera & 14,004 & 221 \\
\hline Haiti & 1963 & & 2724 & 0 \\
\hline Haiti & 2003 & typhiod & 200 & 40 \\
\hline Haiti & 2010 & cholera & 513,997 & 6908 \\
\hline Haiti & 2012 & cholera & 5817 & 50 \\
\hline Haiti & 2014 & chikungunya & 39,343 & 0 \\
\hline Haiti & 2015 & cholera & 20,000 & 170 \\
\hline Haiti & 2016 & cholera & 6096 & 0 \\
\hline Honduras & 1965 & poliovirus & 170 & 7 \\
\hline Honduras & 1995 & dengue and dengue haemorrhagic fever & 15,998 & 5 \\
\hline Honduras & 1998 & cholera & 2452 & 17 \\
\hline Honduras & 2002 & dengue and dengue haemorrhagic fever & 4530 & 8 \\
\hline Honduras & 2009 & dengue and dengue haemorrhagic fever & 11,771 & 7 \\
\hline Honduras & 2010 & dengue and dengue haemorrhagic fever & 27,000 & 67 \\
\hline Honduras & 2013 & dengue and dengue haemorrhagic fever & 34,128 & 27 \\
\hline Honduras & 2019 & dengue and dengue haemorrhagic fever & 71,216 & 128 \\
\hline Hong Kong & 2002 & sars & 1456 & 299 \\
\hline India & 1967 & & 13,576 & 3029 \\
\hline India & 1977 & cholera & 9091 & 0 \\
\hline India & 1978 & & 1000 & 48 \\
\hline
\end{tabular}


Table A18 (continued)

\begin{tabular}{|c|c|c|c|c|}
\hline Country & Year & Epidemic & Total no of affected people & Total no of deaths \\
\hline India & 1984 & dysentery & 27,000 & 3290 \\
\hline India & 1985 & & 6589 & 854 \\
\hline India & 1986 & & 11,600 & 265 \\
\hline India & 1990 & diarrhoeal syndrome & 18,000 & 90 \\
\hline India & 1994 & pneumonia & 5150 & 53 \\
\hline India & 1996 & dengue and dengue haemorrhagic fever & 8423 & 354 \\
\hline India & 1997 & & 890 & 80 \\
\hline India & 1998 & cholera & 15,238 & 807 \\
\hline India & 1999 & & 79,504 & 281 \\
\hline India & 2000 & & 1851 & 191 \\
\hline India & 2001 & cholera & 58,889 & 89 \\
\hline India & 2002 & & 5153 & 50 \\
\hline India & 2003 & dengue and dengue haemorrhagic fever & 2185 & 0 \\
\hline India & 2005 & chikungunya & 155,813 & 640 \\
\hline India & 2009 & encephalitis syndrome (aes) & 1521 & 311 \\
\hline India & 2019 & dengue and dengue haemorrhagic fever & 1318 & 121 \\
\hline Indonesia & 1968 & bubonic & 94 & 40 \\
\hline Indonesia & 1977 & cholera & 29,942 & 37 \\
\hline Indonesia & 1978 & cholera & 70 & 11 \\
\hline Indonesia & 1982 & cholera & 200 & 39 \\
\hline Indonesia & 1984 & & 4000 & 105 \\
\hline Indonesia & 1986 & & 500,700 & 59 \\
\hline Indonesia & 1991 & & 15,000 & 170 \\
\hline Indonesia & 1996 & dengue and dengue haemorrhagic fever & 5373 & 117 \\
\hline Indonesia & 1998 & dengue and dengue haemorrhagic fever & 32,665 & 777 \\
\hline Indonesia & 1999 & dengue and dengue haemorrhagic fever & 4645 & 56 \\
\hline Indonesia & 2000 & dengue and dengue haemorrhagic fever & 1719 & 25 \\
\hline Indonesia & 2002 & shigellosis & 759 & 17 \\
\hline Indonesia & 2004 & dengue and dengue haemorrhagic fever & 58,322 & 745 \\
\hline Indonesia & 2005 & poliovirus & 329 & 0 \\
\hline Indonesia & 2007 & dengue and dengue haemorrhagic fever & 35,211 & 403 \\
\hline Iran (Islamic Republic of) & 1965 & cholera & 2500 & 288 \\
\hline Iraq & 1978 & cholera & 51 & 1 \\
\hline Iraq & 1997 & & 185 & 0 \\
\hline Iraq & 2007 & cholera & 4696 & 24 \\
\hline Iraq & 2008 & cholera & 892 & 11 \\
\hline Iraq & 2015 & cholera & 2217 & 0 \\
\hline Ireland & 2000 & & 1374 & 2 \\
\hline Ireland & 2002 & sars & 1 & 0 \\
\hline Israel & 2000 & west nile fever & 139 & 12 \\
\hline Italy & 2002 & & 10,001 & 3 \\
\hline Jamaica & 1990 & typhiod & 300 & 0 \\
\hline Jamaica & 2006 & & 280 & 3 \\
\hline Japan & 1977 & cholera & 74 & 1 \\
\hline Japan & 1978 & h1n1 & $2,000,000$ & 0 \\
\hline Japan & 1997 & campylobacter & 460 & 0 \\
\hline Jordan & 1981 & cholera & 715 & 4 \\
\hline Kazakhstan & 1998 & & 593 & 7 \\
\hline Kazakhstan & 1999 & typhus & 166 & 0 \\
\hline Kazakhstan & 2000 & typhus & 114 & 0 \\
\hline Kenya & 1991 & & 200 & 26 \\
\hline Kenya & 1994 & & $6,500,000$ & 1000 \\
\hline Kenya & 1997 & cholera & 33,036 & 932 \\
\hline Kenya & 1998 & cholera & 1025 & 27 \\
\hline Kenya & 1999 & & 329,570 & 1814 \\
\hline Kenya & 2000 & cholera & 721 & 50 \\
\hline Kenya & 2001 & & 743 & 40 \\
\hline Kenya & 2004 & & 141 & 8 \\
\hline Kenya & 2005 & & 1645 & 53 \\
\hline Kenya & 2006 & rift valley fever & 588 & 170 \\
\hline Kenya & 2009 & cholera & 10,446 & 251 \\
\hline Kenya & 2010 & cholera & 3880 & 57 \\
\hline Kenya & 2014 & cholera & 3459 & 72 \\
\hline Kenya & 2017 & cholera & 4421 & 76 \\
\hline Kenya & 2019 & cholera & 3847 & 26 \\
\hline Korea (the Republic of) & 1969 & cholera & 1538 & 137 \\
\hline Korea (the Republic of) & 1998 & shigellosis & 350 & 0 \\
\hline Korea (the Republic of) & 2000 & & 39,531 & 6 \\
\hline Korea (the Republic of) & 2002 & sars & 3 & 0 \\
\hline Korea (the Republic of) & 2015 & mers & 185 & 36 \\
\hline Kuwait & 2002 & sars & 1 & 0 \\
\hline Kyrgyzstan & 1997 & & 336 & 22 \\
\hline Kyrgyzstan & 1998 & typhiod & 458 & 0 \\
\hline Kyrgyzstan & 2010 & poliovirus & 141 & 0 \\
\hline Lao People's Dem. Rep. & 1987 & dengue and dengue haemorrhagic fever & 2000 & 63 \\
\hline
\end{tabular}


Table A18 (continued)

\begin{tabular}{|c|c|c|c|c|}
\hline Country & Year & Epidemic & Total no of affected people & Total no of deaths \\
\hline Lao People's Dem. Rep. & 1994 & cholera & 8000 & 500 \\
\hline Lao People's Dem. Rep. & 1995 & cholera & 244 & 34 \\
\hline Lao People's Dem. Rep. & 2000 & & 9685 & 0 \\
\hline Lao People’s Dem. Rep. & 2013 & dengue and dengue haemorrhagic fever & 36,000 & 77 \\
\hline Latvia & 2000 & diphteria & 102 & 0 \\
\hline Lesotho & 1974 & typhiod & 500 & 0 \\
\hline Lesotho & 1999 & dysentery & 1862 & 28 \\
\hline Lesotho & 2000 & & 1834 & 28 \\
\hline Liberia & 1980 & cholera & 1887 & 466 \\
\hline Liberia & 1995 & yellow fever & 359 & 9 \\
\hline Liberia & 1998 & diarrhoeal syndrome & 560 & 12 \\
\hline Liberia & 2000 & cholera & 112 & 3 \\
\hline Liberia & 2002 & diarrhoeal syndrome & 661 & 0 \\
\hline Liberia & 2003 & cholera & 19,418 & 0 \\
\hline Liberia & 2005 & cholera & 674 & 29 \\
\hline Liberia & 2014 & ebola & 10,682 & 4810 \\
\hline Macao & 2002 & sars & 1 & 0 \\
\hline Macedonia FYR & 2002 & unknown & 200 & 0 \\
\hline Madagascar & 1999 & cholera & 18,228 & 981 \\
\hline Madagascar & 2002 & h1n1 & 21,975 & 671 \\
\hline Madagascar & 2008 & rift valley fever & 520 & 20 \\
\hline Madagascar & 2009 & chikungunya & 702 & 0 \\
\hline Madagascar & 2013 & pneumonia & 660 & 113 \\
\hline Madagascar & 2017 & plague & 2384 & 207 \\
\hline Madagascar & 2018 & measles & 98,415 & 0 \\
\hline Malawi & 1989 & & 444 & 35 \\
\hline Malawi & 1997 & & 622 & 10 \\
\hline Malawi & 2000 & cholera & 3323 & 83 \\
\hline Malawi & 2001 & cholera & 40,266 & 1131 \\
\hline Malawi & 2002 & cholera & 773 & 41 \\
\hline Malawi & 2006 & cholera & 852 & 20 \\
\hline Malawi & 2008 & cholera & 5269 & 113 \\
\hline Malawi & 2009 & measles & 11,461 & 62 \\
\hline Malawi & 2014 & cholera & 693 & 11 \\
\hline Malawi & 2017 & cholera & 450 & 6 \\
\hline Malaysia & 1968 & cholera & 5 & 2 \\
\hline Malaysia & 1977 & typhiod & 50 & 0 \\
\hline Malaysia & 1991 & dengue and dengue haemorrhagic fever & 3750 & 263 \\
\hline Malaysia & 1996 & dengue and dengue haemorrhagic fever & 5407 & 13 \\
\hline Malaysia & 1997 & dengue and dengue haemorrhagic fever & 21,684 & 78 \\
\hline Malaysia & 1998 & encephalitis syndrome (aes) & 160 & 105 \\
\hline Malaysia & 2000 & enterovirus & 988 & 4 \\
\hline Malaysia & 2002 & sars & 3 & 2 \\
\hline Maldives & 1978 & cholera & 11,258 & 219 \\
\hline Maldives & 2011 & dengue and dengue haemorrhagic fever & 1289 & 4 \\
\hline Mali & 1969 & & 4023 & 513 \\
\hline Mali & 1979 & & 80 & 30 \\
\hline Mali & 1981 & & 4153 & 412 \\
\hline Mali & 1984 & cholera & 4502 & 1022 \\
\hline Mali & 1987 & yellow fever & 305 & 145 \\
\hline Mali & 1988 & & 159 & 47 \\
\hline Mali & 1996 & meningitis & 2208 & 345 \\
\hline Mali & 1997 & & 9666 & 1098 \\
\hline Mali & 2002 & & 282 & 33 \\
\hline Mali & 2003 & cholera & 1216 & 106 \\
\hline Mali & 2005 & cholera & 168 & 43 \\
\hline Mali & 2006 & & 151 & 9 \\
\hline Mali & 2009 & meningitis & 86 & 10 \\
\hline Mali & 2011 & cholera & 1190 & 49 \\
\hline Mali & 2014 & ebola & 7 & 6 \\
\hline Mauritania & 1982 & & 12 & 5 \\
\hline Mauritania & 1987 & yellow fever & 178 & 35 \\
\hline Mauritania & 1988 & cholera & 575 & 38 \\
\hline Mauritania & 1998 & rift valley fever & 344 & 6 \\
\hline Mauritania & 2005 & cholera & 2585 & 55 \\
\hline Mauritius & 1980 & typhiod & 108 & 0 \\
\hline Mauritius & 2005 & chikungunya & 2553 & 0 \\
\hline Mexico & 1991 & cholera & 5000 & 52 \\
\hline Mexico & 1995 & dengue and dengue haemorrhagic fever & 6525 & 16 \\
\hline Mexico & 2009 & dengue and dengue haemorrhagic fever & 41,687 & 0 \\
\hline Moldova & 1999 & & 1647 & 0 \\
\hline Mongolia & 1996 & cholera & 108 & 8 \\
\hline Mongolia & 2002 & sars & 9 & 0 \\
\hline Mongolia & 2008 & enterovirus & 3151 & 0 \\
\hline Morocco & 1966 & meningitis & 2942 & 200 \\
\hline
\end{tabular}


Table A18 (continued)

\begin{tabular}{|c|c|c|c|c|}
\hline Country & Year & Epidemic & Total no of affected people & Total no of deaths \\
\hline Mozambique & 1980 & cholera & 200 & 10 \\
\hline Mozambique & 1983 & cholera & 5679 & 189 \\
\hline Mozambique & 1990 & cholera & 4000 & 588 \\
\hline Mozambique & 1992 & cholera & 225,673 & 587 \\
\hline Mozambique & 1997 & cholera & 27,201 & 637 \\
\hline Mozambique & 1998 & cholera & 2600 & 209 \\
\hline Mozambique & 2000 & & 18,583 & 11 \\
\hline Mozambique & 2001 & cholera & 611 & 7 \\
\hline Mozambique & 2002 & cholera & 2028 & 17 \\
\hline Mozambique & 2003 & cholera & 24,134 & 159 \\
\hline Mozambique & 2006 & cholera & 5692 & 27 \\
\hline Mozambique & 2007 & cholera & 7547 & 78 \\
\hline Mozambique & 2008 & cholera & 19,310 & 155 \\
\hline Mozambique & 2009 & cholera & 19,776 & 198 \\
\hline Mozambique & 2010 & cholera & 3188 & 44 \\
\hline Mozambique & 2011 & cholera & 325 & 13 \\
\hline Mozambique & 2013 & cholera & 317 & 2 \\
\hline Mozambique & 2014 & cholera & 5118 & 43 \\
\hline Mozambique & 2017 & cholera & 1799 & 1 \\
\hline Mozambique & 2019 & cholera & 3577 & 0 \\
\hline Myanmar & 1983 & & 800 & 10 \\
\hline Namibia & 2000 & meningitis & 58 & 14 \\
\hline Namibia & 2001 & & 12,098 & 134 \\
\hline Namibia & 2006 & poliovirus & 47 & 10 \\
\hline Namibia & 2007 & cholera & 250 & 7 \\
\hline Namibia & 2008 & cholera & 203 & 9 \\
\hline Namibia & 2013 & cholera & 518 & 17 \\
\hline Nepal & 1963 & & 5000 & 1000 \\
\hline Nepal & 1967 & bubonic & 24 & 17 \\
\hline Nepal & 1982 & & 1475 & 0 \\
\hline Nepal & 1990 & cholera & 3800 & 150 \\
\hline Nepal & 1991 & diarrhoeal syndrome & 45,341 & 1334 \\
\hline Nepal & 1992 & diarrhoeal syndrome & 50,000 & 640 \\
\hline Nepal & 1995 & encephalitis syndrome (aes) & 772 & 126 \\
\hline Nepal & 1996 & encephalitis syndrome (aes) & 697 & 118 \\
\hline Nepal & 1997 & encephalitis syndrome (aes) & 1364 & 84 \\
\hline Nepal & 1998 & encephalitis syndrome (aes) & 300 & 52 \\
\hline Nepal & 1999 & encephalitis syndrome (aes) & 944 & 150 \\
\hline Nepal & 2000 & encephalitis syndrome (aes) & 592 & 69 \\
\hline Nepal & 2001 & diarrhoeal syndrome & 242 & 13 \\
\hline Nepal & 2009 & diarrhoeal syndrome & 58,874 & 314 \\
\hline Nepal & 2010 & diarrhoeal syndrome & 5372 & 73 \\
\hline Netherlands (the) & 1999 & legionellosis & 200 & 13 \\
\hline New Zealand & 2002 & sars & 1 & 0 \\
\hline Nicaragua & 1967 & & 444 & 53 \\
\hline Nicaragua & 1991 & cholera & 381 & 2 \\
\hline Nicaragua & 1995 & dengue and dengue haemorrhagic fever & 13,406 & 18 \\
\hline Nicaragua & 1998 & cholera & 3356 & 7 \\
\hline Nicaragua & 2009 & dengue and dengue haemorrhagic fever & 2050 & 8 \\
\hline Nicaragua & 2010 & leptospirosis & 395 & 16 \\
\hline Nicaragua & 2013 & dengue and dengue haemorrhagic fever & 1310 & 3 \\
\hline Nicaragua & 2019 & dengue and dengue haemorrhagic fever & 94,513 & 15 \\
\hline Niger (the) & 1969 & yellow fever & 5 & 2 \\
\hline Niger (the) & 1970 & & 2677 & 319 \\
\hline Niger (the) & 1989 & & 1785 & 186 \\
\hline Niger (the) & 1991 & & 90,147 & 2842 \\
\hline Niger (the) & 1995 & & 63,691 & 3022 \\
\hline Niger (the) & 1996 & & 10,475 & 882 \\
\hline Niger (the) & 1997 & & 2156 & 262 \\
\hline Niger (the) & 1999 & & 741 & 49 \\
\hline Niger (the) & 2000 & & 1151 & 190 \\
\hline Niger (the) & 2001 & & 48,067 & 573 \\
\hline Niger (the) & 2002 & meningitis & 3306 & 316 \\
\hline Niger (the) & 2003 & & 1861 & 195 \\
\hline Niger (the) & 2004 & & 20,132 & 154 \\
\hline Niger (the) & 2005 & cholera & 387 & 44 \\
\hline Niger (the) & 2006 & meningitis & 784 & 62 \\
\hline Niger (the) & 2008 & meningitis & 2805 & 173 \\
\hline Niger (the) & 2009 & meningitis & 4513 & 169 \\
\hline Niger (the) & 2010 & meningitis & 1217 & 103 \\
\hline Niger (the) & 2011 & cholera & 2130 & 48 \\
\hline Niger (the) & 2012 & cholera & 4874 & 97 \\
\hline Niger (the) & 2014 & meningitis & 1639 & 153 \\
\hline Niger (the) & 2015 & measles & 3370 & 6 \\
\hline Niger (the) & 2016 & rift valley fever & 78 & 23 \\
\hline
\end{tabular}


Table A18 (continued)

\begin{tabular}{|c|c|c|c|c|}
\hline Country & Year & Epidemic & Total no of affected people & Total no of deaths \\
\hline Niger (the) & 2017 & meningitis & 2390 & 118 \\
\hline Niger (the) & 2018 & cholera & 3824 & 78 \\
\hline Nigeria & 1969 & yellow fever & 80,000 & 2000 \\
\hline Nigeria & 1986 & yellow fever & 1400 & 1073 \\
\hline Nigeria & 1987 & & 120 & 100 \\
\hline Nigeria & 1989 & haemorrhagic fever syndrome & 41 & 29 \\
\hline Nigeria & 1991 & cholera & 11,200 & 7689 \\
\hline Nigeria & 1996 & cerebro spinal & 42,586 & 5539 \\
\hline Nigeria & 1998 & acute neurological syndrome & 211 & 39 \\
\hline Nigeria & 1999 & diarrhoeal syndrome & 2977 & 486 \\
\hline Nigeria & 2000 & cholera & 1255 & 87 \\
\hline Nigeria & 2001 & cholera & 2636 & 204 \\
\hline Nigeria & 2002 & diarrhoeal syndrome & 3903 & 229 \\
\hline Nigeria & 2004 & cholera & 1897 & 172 \\
\hline Nigeria & 2005 & & 23,873 & 619 \\
\hline Nigeria & 2008 & unknown & 66 & 46 \\
\hline Nigeria & 2009 & meningitis & 35,255 & 1701 \\
\hline Nigeria & 2010 & cholera & 43,287 & 1872 \\
\hline Nigeria & 2011 & cholera & 21,382 & 694 \\
\hline Nigeria & 2012 & haemorrhagic fever syndrome & 29 & 10 \\
\hline Nigeria & 2014 & cholera & 36,017 & 763 \\
\hline Nigeria & 2015 & cholera & 2108 & 97 \\
\hline Nigeria & 2016 & meningitis & 15,432 & 1287 \\
\hline Nigeria & 2017 & cholera & 1704 & 11 \\
\hline Nigeria & 2018 & haemorrhagic fever syndrome & 1081 & 90 \\
\hline Nigeria & 2019 & measles & 22,834 & 98 \\
\hline Nigeria & 2020 & haemorrhagic fever syndrome & 365 & 47 \\
\hline Pakistan & 1968 & cholera & 1075 & 37 \\
\hline Pakistan & 1998 & cholera & 9917 & 83 \\
\hline Pakistan & 2000 & diarrhoeal syndrome & 258 & 14 \\
\hline Pakistan & 2001 & leishmaniasis & 5000 & 0 \\
\hline Pakistan & 2002 & unknown & 25 & 10 \\
\hline Pakistan & 2004 & & 100 & 2 \\
\hline Pakistan & 2005 & tetanos & 111 & 22 \\
\hline Pakistan & 2017 & dengue and dengue haemorrhagic fever & 2492 & 25 \\
\hline Pakistan & 2019 & dengue and dengue haemorrhagic fever & 53,834 & 95 \\
\hline Palestine, State of & 1983 & & 943 & 0 \\
\hline Panama & 1964 & & 1200 & 0 \\
\hline Panama & 1991 & cholera & 2057 & 43 \\
\hline Panama & 1995 & dengue and dengue haemorrhagic fever & 2124 & 1 \\
\hline Panama & 2002 & meningitis & 173 & 0 \\
\hline Papua New Guinea & 2001 & & 1395 & 0 \\
\hline Papua New Guinea & 2002 & & 2215 & 122 \\
\hline Papua New Guinea & 2009 & h1n1 & 7391 & 192 \\
\hline Paraguay & 1999 & dengue and dengue haemorrhagic fever & 2273 & 0 \\
\hline Paraguay & 2006 & dengue and dengue haemorrhagic fever & 100,000 & 17 \\
\hline Paraguay & 2008 & dengue and dengue haemorrhagic fever & 5957 & 8 \\
\hline Paraguay & 2009 & dengue and dengue haemorrhagic fever & 24 & 8 \\
\hline Paraguay & 2010 & dengue and dengue haemorrhagic fever & 13,681 & 0 \\
\hline Paraguay & 2011 & dengue and dengue haemorrhagic fever & 16,264 & 44 \\
\hline Paraguay & 2020 & dengue and dengue haemorrhagic fever & 106,127 & 20 \\
\hline Peru & 1991 & cholera & 283,353 & 1726 \\
\hline Peru & 1997 & cholera & 174 & 1 \\
\hline Peru & 1998 & cholera & 33,763 & 16 \\
\hline Peru & 2009 & dengue and dengue haemorrhagic fever & 14,151 & 0 \\
\hline Peru & 2010 & dengue and dengue haemorrhagic fever & 31,703 & 13 \\
\hline Peru & 2012 & dengue and dengue haemorrhagic fever & 20,106 & 11 \\
\hline Peru & 2016 & yellow fever & 54 & 26 \\
\hline Philippines (the) & 1977 & & 681 & 57 \\
\hline Philippines (the) & 1990 & & 200 & 21 \\
\hline Philippines (the) & 1996 & dengue and dengue haemorrhagic fever & 1673 & 30 \\
\hline Philippines (the) & 1998 & dengue and dengue haemorrhagic fever & 11,000 & 202 \\
\hline Philippines (the) & 1999 & dengue and dengue haemorrhagic fever & 402 & 10 \\
\hline Philippines (the) & 2000 & diarrhoeal syndrome & 664 & 1 \\
\hline Philippines (the) & 2002 & sars & 12 & 2 \\
\hline Philippines (the) & 2004 & meningitis & 98 & 32 \\
\hline Philippines (the) & 2010 & dengue and dengue haemorrhagic fever & 123,939 & 737 \\
\hline Philippines (the) & 2011 & dengue and dengue haemorrhagic fever & 7595 & 56 \\
\hline Philippines (the) & 2012 & cholera & 3158 & 30 \\
\hline Philippines (the) & 2018 & dengue and dengue haemorrhagic fever & 79,376 & 519 \\
\hline Philippines (the) & 2019 & dengue and dengue haemorrhagic fever & 129,597 & 825 \\
\hline Romania & 1996 & & 527 & 0 \\
\hline Romania & 1999 & & 4743 & 0 \\
\hline Romania & 2002 & sars & 1 & 0 \\
\hline Russian Federation & 1995 & & 150,000 & 0 \\
\hline
\end{tabular}


Table A18 (continued)

\begin{tabular}{|c|c|c|c|c|}
\hline Country & Year & Epidemic & Total no of affected people & Total no of deaths \\
\hline Russian Federation & 1997 & haemorrhagic fever syndrome & 4538 & 0 \\
\hline Russian Federation & 1999 & west nile fever & 765 & 33 \\
\hline Russian Federation & 2000 & acute jaundice syndrome & 2942 & 0 \\
\hline Russian Federation & 2002 & sars & 1 & 0 \\
\hline Rwanda & 1978 & cholera & 2000 & 0 \\
\hline Rwanda & 1991 & & 214 & 32 \\
\hline Rwanda & 1996 & cholera & 106 & 10 \\
\hline Rwanda & 1998 & cholera & 2951 & 55 \\
\hline Rwanda & 1999 & & 488 & 76 \\
\hline Rwanda & 2000 & meningitis & 164 & 10 \\
\hline Rwanda & 2002 & meningitis & 636 & 83 \\
\hline Rwanda & 2004 & typhiod & 540 & 4 \\
\hline Rwanda & 2006 & cholera & 300 & 35 \\
\hline Sao Tome and Principe & 1989 & cholera & 1063 & 31 \\
\hline Sao Tome and Principe & 2005 & cholera & 1349 & 25 \\
\hline Saudi Arabia & 2000 & rift valley fever & 497 & 133 \\
\hline Saudi Arabia & 2001 & meningitis & 74 & 35 \\
\hline Senegal & 1965 & yellow fever & 150 & 60 \\
\hline Senegal & 1978 & cholera & 298 & 5 \\
\hline Senegal & 1985 & cholera & 3100 & 300 \\
\hline Senegal & 1995 & cholera & 3031 & 188 \\
\hline Senegal & 1998 & & 2709 & 372 \\
\hline Senegal & 2002 & & 181 & 18 \\
\hline Senegal & 2004 & cholera & 861 & 6 \\
\hline Senegal & 2005 & cholera & 23,022 & 303 \\
\hline Senegal & 2007 & cholera & 2825 & 16 \\
\hline Senegal & 2014 & ebola & 1 & 0 \\
\hline Seychelles & 2005 & chikungunya & 5461 & 0 \\
\hline Seychelles & 2016 & dengue and dengue haemorrhagic fever & 253 & 0 \\
\hline Sierra Leone & 1985 & cholera & 3000 & 352 \\
\hline Sierra Leone & 1996 & haemorrhagic fever syndrome & 953 & 226 \\
\hline Sierra Leone & 1997 & h1n1 & 2024 & 51 \\
\hline Sierra Leone & 1998 & cholera & 1770 & 55 \\
\hline Sierra Leone & 1999 & dysentery & 3228 & 133 \\
\hline Sierra Leone & 2001 & meningitis & 3 & 12 \\
\hline Sierra Leone & 2003 & yellow fever & 90 & 10 \\
\hline Sierra Leone & 2004 & cholera & 633 & 56 \\
\hline Sierra Leone & 2008 & cholera & 1746 & 170 \\
\hline Sierra Leone & 2012 & cholera & 23,009 & 300 \\
\hline Sierra Leone & 2014 & ebola & 14,124 & 3956 \\
\hline Singapore & 1998 & encephalitis syndrome (aes) & 11 & 1 \\
\hline Singapore & 2000 & enterovirus & 2022 & 2 \\
\hline Singapore & 2002 & sars & 205 & 33 \\
\hline Singapore & 2016 & dengue and dengue haemorrhagic fever & 13,051 & 0 \\
\hline Solomon Islands & 2013 & dengue and dengue haemorrhagic fever & 6700 & 8 \\
\hline Solomon Islands & 2016 & dengue and dengue haemorrhagic fever & 1212 & 0 \\
\hline Somalia & 1977 & & 2671 & 0 \\
\hline Somalia & 1985 & cholera & 4815 & 1262 \\
\hline Somalia & 1986 & cholera & 7093 & 1307 \\
\hline Somalia & 1994 & & 17,000 & 100 \\
\hline Somalia & 1996 & cholera & 5557 & 247 \\
\hline Somalia & 1997 & cholera & 1044 & 0 \\
\hline Somalia & 1998 & cholera & 14,564 & 481 \\
\hline Somalia & 1999 & cholera & 175 & 15 \\
\hline Somalia & 2000 & cholera & 2490 & 244 \\
\hline Somalia & 2001 & meningitis & 111 & 33 \\
\hline Somalia & 2002 & cholera & 1191 & 63 \\
\hline Somalia & 2005 & poliovirus & 199 & 0 \\
\hline Somalia & 2006 & & 5876 & 103 \\
\hline Somalia & 2007 & cholera & 35,687 & 1133 \\
\hline Somalia & 2008 & cholera & 663 & 13 \\
\hline Somalia & 2016 & cholera & 14,165 & 497 \\
\hline Somalia & 2017 & cholera & 13,126 & 302 \\
\hline South Africa & 2000 & cholera & 86,107 & 181 \\
\hline South Africa & 2002 & cholera & 13,352 & 84 \\
\hline South Africa & 2004 & cholera & 174 & 5 \\
\hline South Africa & 2008 & cholera & 12,752 & 65 \\
\hline South Sudan & 2013 & poliovirus & 3 & 0 \\
\hline South Sudan & 2014 & cholera & 6486 & 149 \\
\hline South Sudan & 2015 & cholera & 1818 & 47 \\
\hline South Sudan & 2016 & cholera & 3826 & 68 \\
\hline South Sudan & 2019 & measles & 937 & 7 \\
\hline Spain & 1997 & meningitis & 1383 & 0 \\
\hline Spain & 2001 & legionellosis & 751 & 2 \\
\hline Spain & 2002 & sars & 1 & 0 \\
\hline
\end{tabular}


Table A18 (continued)

\begin{tabular}{|c|c|c|c|c|}
\hline Country & Year & Epidemic & Total no of affected people & Total no of deaths \\
\hline Sri Lanka & 1967 & & 200,000 & 2 \\
\hline Sri Lanka & 1977 & cholera & 728 & 0 \\
\hline Sri Lanka & 1997 & cholera & 1695 & 36 \\
\hline Sri Lanka & 1999 & & 5936 & 1 \\
\hline Sri Lanka & 2000 & dengue and dengue haemorrhagic fever & 113 & 2 \\
\hline Sri Lanka & 2004 & dengue and dengue haemorrhagic fever & 15,000 & 88 \\
\hline Sri Lanka & 2009 & dengue and dengue haemorrhagic fever & 35,007 & 346 \\
\hline Sri Lanka & 2011 & dengue and dengue haemorrhagic fever & 26,343 & 167 \\
\hline Sri Lanka & 2017 & dengue and dengue haemorrhagic fever & 155,715 & 320 \\
\hline Sri Lanka & 2019 & dengue and dengue haemorrhagic fever & 18,760 & 28 \\
\hline Sudan (the) & 1940 & yellow fever & 15,000 & 1500 \\
\hline Sudan (the) & 1950 & & 72,162 & 0 \\
\hline Sudan (the) & 1965 & & 2300 & 0 \\
\hline Sudan (the) & 1976 & ebola & 299 & 150 \\
\hline Sudan (the) & 1988 & & 38,805 & 2770 \\
\hline Sudan (the) & 1996 & cholera & 1800 & 700 \\
\hline Sudan (the) & 1998 & meningitis & 22,403 & 1746 \\
\hline Sudan (the) & 1999 & cholera & 3959 & 357 \\
\hline Sudan (the) & 2000 & & 2363 & 186 \\
\hline Sudan (the) & 2002 & leishmaniasis & 1281 & 49 \\
\hline Sudan (the) & 2003 & yellow fever & 178 & 27 \\
\hline Sudan (the) & 2004 & hepatitis e & 8114 & 98 \\
\hline Sudan (the) & 2005 & meningitis & 7454 & 650 \\
\hline Sudan (the) & 2006 & cholera & 28,769 & 1142 \\
\hline Sudan (the) & 2007 & meningitis & 7639 & 584 \\
\hline Sudan (the) & 2008 & diarrhoeal syndrome & 212 & 15 \\
\hline Sudan (the) & 2012 & yellow fever & 678 & 171 \\
\hline Sudan (the) & 2016 & & 632 & 19 \\
\hline Sudan (the) & 2017 & diarrhoeal syndrome & 30,762 & 657 \\
\hline Sudan (the) & 2019 & cholera & 510 & 24 \\
\hline Swaziland & 1992 & cholera & 2228 & 30 \\
\hline Swaziland & 2000 & cholera & 1449 & 32 \\
\hline Sweden & 2002 & diarrhoeal syndrome & 350 & 0 \\
\hline Switzerland & 2002 & sars & 1 & 0 \\
\hline Syrian Arab Rep. & 1977 & cholera & 4165 & 88 \\
\hline Taiwan (Prov. of China) & 1998 & encephalitis syndrome (aes) & 250,000 & 54 \\
\hline Taiwan (Prov. of China) & 2002 & sars & 309 & 37 \\
\hline Tajikistan & 1996 & typhiod & 7516 & 0 \\
\hline Tajikistan & 1997 & typhiod & 15,618 & 168 \\
\hline Tajikistan & 1999 & typhiod & 200 & 3 \\
\hline Tajikistan & 2003 & typhiod & 256 & 0 \\
\hline Tajikistan & 2010 & poliovirus & 456 & 21 \\
\hline Tanzania & 1977 & cholera & 6050 & 500 \\
\hline Tanzania & 1985 & bubonic & 118 & 10 \\
\hline Tanzania & 1987 & cholera & 500 & 90 \\
\hline Tanzania & 1991 & & 1733 & 284 \\
\hline Tanzania & 1992 & cholera & 40,249 & 2231 \\
\hline Tanzania & 1997 & cholera & 42,350 & 2329 \\
\hline Tanzania & 1998 & cholera & 40,677 & 2461 \\
\hline Tanzania & 1999 & diarrhoeal syndrome & 529 & 56 \\
\hline Tanzania & 2000 & & 898 & 37 \\
\hline Tanzania & 2001 & diarrhoeal syndrome & 515 & 25 \\
\hline Tanzania & 2002 & meningitis & 149 & 9 \\
\hline Tanzania & 2005 & cholera & 576 & 6 \\
\hline Tanzania & 2006 & cholera & 1410 & 70 \\
\hline Tanzania & 2007 & rift valley fever & 284 & 119 \\
\hline Tanzania & 2009 & cholera & 600 & 12 \\
\hline Tanzania & 2015 & cholera & 37,712 & 582 \\
\hline Tanzania & 2019 & cholera & 216 & 3 \\
\hline Thailand & 1977 & cholera & 2800 & 100 \\
\hline Thailand & 2000 & & 1946 & 89 \\
\hline Thailand & 2002 & sars & 7 & 2 \\
\hline Thailand & 2003 & h5n1 & 4 & 7 \\
\hline Thailand & 2004 & h5n1 & 8 & 14 \\
\hline Thailand & 2010 & dengue and dengue haemorrhagic fever & 880 & 2 \\
\hline Thailand & 2011 & dengue and dengue haemorrhagic fever & 37,728 & 27 \\
\hline Timor-Leste & 2005 & dengue and dengue haemorrhagic fever & 336 & 22 \\
\hline Timor-Leste & 2014 & dengue and dengue haemorrhagic fever & 197 & 2 \\
\hline Togo & 1988 & & 1617 & 50 \\
\hline Togo & 1996 & & 2619 & 360 \\
\hline Togo & 1998 & cholera & 3669 & 239 \\
\hline Togo & 2001 & meningitis & 1567 & 235 \\
\hline Togo & 2002 & & 494 & 95 \\
\hline Togo & 2003 & cholera & 790 & 40 \\
\hline Togo & 2008 & cholera & 686 & 6 \\
\hline
\end{tabular}


Table A18 (continued)

\begin{tabular}{|c|c|c|c|c|}
\hline Country & Year & Epidemic & Total no of affected people & Total no of deaths \\
\hline Togo & 2010 & meningitis & 236 & 60 \\
\hline Togo & 2013 & cholera & 168 & 7 \\
\hline Togo & 2015 & meningitis & 324 & 24 \\
\hline Turkey & 1964 & & 2500 & 19 \\
\hline Turkey & 1965 & & 100,000 & 461 \\
\hline Turkey & 1968 & poliovirus & 1975 & 98 \\
\hline Turkey & 1977 & & 100,000 & 0 \\
\hline Turkey & 1987 & cholera & 150 & 11 \\
\hline Turkey & 2004 & h5n1 & 8 & 4 \\
\hline Turkey & 2006 & haemorrhagic fever syndrome & 222 & 20 \\
\hline Uganda & 1982 & plague & 153 & 3 \\
\hline Uganda & 1986 & plague & 340 & 27 \\
\hline Uganda & 1989 & meningitis & 961 & 156 \\
\hline Uganda & 1990 & meningitis & 1170 & 197 \\
\hline Uganda & 1997 & o'nyongnyong fever & 100,300 & 0 \\
\hline Uganda & 1998 & cholera & 600 & 30 \\
\hline Uganda & 1999 & cholera & 2205 & 122 \\
\hline Uganda & 2000 & ebola & 723 & 259 \\
\hline Uganda & 2001 & & 9 & 14 \\
\hline Uganda & 2003 & cholera & 242 & 35 \\
\hline Uganda & 2004 & cholera & 53 & 3 \\
\hline Uganda & 2005 & cholera & 726 & 21 \\
\hline Uganda & 2006 & meningitis & 5702 & 203 \\
\hline Uganda & 2007 & hepatitis e & 5937 & 132 \\
\hline Uganda & 2008 & cholera & 388 & 28 \\
\hline Uganda & 2009 & cholera & 544 & 17 \\
\hline Uganda & 2010 & yellow fever & 190 & 48 \\
\hline Uganda & 2012 & cholera & 5980 & 156 \\
\hline Uganda & 2013 & cholera & 218,497 & 28 \\
\hline Uganda & 2018 & cholera & 1000 & 31 \\
\hline Ukraine & 1994 & cholera & 1333 & 71 \\
\hline Ukraine & 1995 & & 5336 & 204 \\
\hline Ukraine & 1997 & & 102 & 0 \\
\hline United Kingdom & 1984 & salmonella & 16 & 26 \\
\hline United Kingdom & 1985 & legionellosis & 144 & 34 \\
\hline United Kingdom & 2001 & meningitis & 30 & 11 \\
\hline United Kingdom & 2002 & sars & 4 & 0 \\
\hline USA & 1990 & encephalitis syndrome (aes) & 50 & 3 \\
\hline USA & 1993 & cryptosporidiosis & 403,000 & 100 \\
\hline USA & 2002 & west nile fever & 3653 & 214 \\
\hline Uzbekistan & 1998 & & 148 & 40 \\
\hline Venezuela & 1990 & dengue and dengue haemorrhagic fever & 9506 & 74 \\
\hline Venezuela & 1991 & cholera & 967 & 18 \\
\hline Venezuela & 1995 & dengue and dengue haemorrhagic fever & 32,280 & 0 \\
\hline Venezuela & 2010 & cholera & 118 & 0 \\
\hline Viet Nam & 1964 & cholera & 10,848 & 598 \\
\hline Viet Nam & 1996 & dengue and dengue haemorrhagic fever & 9706 & 45 \\
\hline Viet Nam & 1998 & dengue and dengue haemorrhagic fever & 8000 & 214 \\
\hline Viet Nam & 2002 & sars & 58 & 5 \\
\hline Viet Nam & 2003 & h5n1 & 8 & 15 \\
\hline Viet Nam & 2004 & h5n1 & 51 & 42 \\
\hline Viet Nam & 2005 & acute neurological syndrome & 83 & 16 \\
\hline Viet Nam & 2016 & dengue and dengue haemorrhagic fever & 79,204 & 27 \\
\hline Yemen & 2000 & rift valley fever & 289 & 32 \\
\hline Yemen & 2005 & poliovirus & 179 & 0 \\
\hline Yemen & 2015 & & 3026 & 3 \\
\hline Yemen & 2016 & cholera & 180 & 11 \\
\hline Yemen & 2017 & diphteria & 298 & 35 \\
\hline Yemen & 2019 & cholera & 521,028 & 932 \\
\hline Zambia & 1990 & yellow fever & 667 & 85 \\
\hline Zambia & 1991 & cholera & 13,154 & 0 \\
\hline Zambia & 1992 & cholera & 11,659 & 0 \\
\hline Zambia & 1999 & cholera & 13,083 & 462 \\
\hline Zambia & 2000 & cholera & 1224 & 163 \\
\hline Zambia & 2001 & plague & 425 & 11 \\
\hline Zambia & 2003 & cholera & 3835 & 179 \\
\hline Zambia & 2005 & cholera & 7615 & 21 \\
\hline Zambia & 2006 & cholera & 105 & 5 \\
\hline Zambia & 2007 & cholera & 115 & 5 \\
\hline Zambia & 2008 & cholera & 8312 & 173 \\
\hline Zambia & 2009 & cholera & 5198 & 87 \\
\hline Zambia & 2012 & cholera & 153 & 2 \\
\hline Zambia & 2017 & cholera & 4371 & 89 \\
\hline Zimbabwe & 1992 & cholera & 5649 & 258 \\
\hline Zimbabwe & 1996 & & 500,000 & 1311 \\
\hline
\end{tabular}


Table A18 (continued)

\begin{tabular}{|c|c|c|c|c|}
\hline Country & Year & Epidemic & Total no of affected people & Total no of deaths \\
\hline Zimbabwe & 1998 & cholera & 377 & 22 \\
\hline Zimbabwe & 1999 & cholera & 462 & 52 \\
\hline Zimbabwe & 2000 & cholera & 2812 & 112 \\
\hline Zimbabwe & 2002 & cholera & 452 & 4 \\
\hline Zimbabwe & 2003 & cholera & 750 & 40 \\
\hline Zimbabwe & 2005 & cholera & 1183 & 87 \\
\hline Zimbabwe & 2007 & & 10,000 & 67 \\
\hline Zimbabwe & 2008 & cholera & 98,349 & 4276 \\
\hline Zimbabwe & 2009 & measles & 1346 & 55 \\
\hline Zimbabwe & 2010 & typhiod & 258 & 8 \\
\hline Zimbabwe & 2011 & cholera & 1140 & 45 \\
\hline Zimbabwe & 2014 & cholera & 11 & 0 \\
\hline Zimbabwe & 2018 & typhiod & 5164 & 12 \\
\hline
\end{tabular}

\section{References}

Aassve, A., Alfani, G., Gandolfi, F., Le Moglie, M., 2020. Epidemics and trust: the case of the spanish flu. Mimeo.

Angrist, J.D., Pischke, J.-S., 2009. Mostly Harmless Econometrics: An Empiricist's Companion. Princeton University Press.

Agley, J., 2020. Assessing changes in US public trust in science amid the Covid-19 pandemic. Public Health 183, 122-125.

Aksoy, C.G., Eichengreen, B., Saka, O., 2020. The Political Scar of Epidemics. NBER Working Paper No. 27401.

Bol, D., Giani, M., Blais, A.A., Loewen, P.J., 2020. The effect of COVID-19 lockdowns on political support: Some good news for democracy? Eur. J. Polit. Res. In press.

Converse, P.E., 1976. The Dynamics of Party Support: Cohort-Analyzing Party Identification. Sage, Beverly Hills, CA.

Dawson, R., Prewitt, K., 1969. Political Socialization. Little, Brown \& Co, Boston.

Dieckmann, N.F., Johnson, B.B., 2019. Why do scientists disagree? Explaining and improving measures of the perceived causes of scientific disputes. PloS One 14 (2), e0211269.

Drummond, C., Fischhoff, B., 2017. Individuals with greater science literacy and education have more polarized beliefs on controversial science topics. Proc. Natl. Acad. Sci. 114 (36), 9587-9592.

Erikson, E., 1968. Identity, Youth and Crisis. Norton, New York.

Etchegaray, N., Scherman, A., Valenzuela, S., 2018. Testing the hypothesis of 'impressionable years' with willingness to self-sensor in Chile. Int. J. Public Opin. Res. 31, 331-348.

Farzanegan, M.R., Fereidouni, H.G., 2019. Growing up in the Iran-Iraq war and preferences for strong defense, No. 07-2019. MAGKS Joint Discussion Paper Series in Economics.

Fiske, S.T., Dupree, C., 2014. Gaining trust as well as respect in communicating to motivated audiences about science topics. Proc. Natl. Acad. Sci. 111 (Supplement 4), 13593-13597.

Fluckiger, M., Ludwig, M., Sina Onder, A., 2019. Ebola and State Legitimacy. Econ. J. 129, 2064-2089.

Friedman, L., Plumer, B., 2020. Trump's Response to Virus Reflects a Long Disregard for Science. New York Times (28 April). Available at: https://www.nytimes.com/ 2020/04/28/climate/trump-coronavirus-climate-science.html (accessed 18 May 2020).
Gauchat, G., 2012. Politicization of science in the public sphere: A study of public trust in the United States, 1974 to 2010 . Am. Sociol. Rev. 77 (2), 167-187.

Giuliano, P., Spilimbergo, A., 2013. Growing up in a recession. Rev. Econ. Stud. 81 (2), 787-817.

IFPRI, 2020. Trust in science and in government plays a crucial role in COVID-19 response. Available at: https://www.ifpri.org/blog/trust-science-andgovernment-plays-crucial-role-covid-19-response.

Krosnick, J., Alwin, D., 1989. Aging and susceptibility to attitude change. J. Personal. Soc. Psychol. 57, 416-425.

Newcomb, T., 1943. Personality and Social Change: Attitude Formation in a Student Community. Dryden, New York.

Newcomb, T., Koenig, K., Flacks, R., Warwick, D., 1967. Persistence and Change: Bennington College and Its Students After 25 Years. Wiley, New York.

Niemi, R., Sobieszek, B., 1977. Political Socialization. Annu. Rev. Sociol. 3, 209-233.

Oster, E., 2019. Unobservable selection and coefficient stability: Theory and evidence. J. Bus. Econ. Stat. 37 (2), 187-204.

Sapienza, P., Zingales, L., 2013. Economic experts versus average Americans. Am. Econ. Rev. 103 (3), 636-642.

Scheufele, D.A., 2013. Communicating science in social settings. Proc. Natl. Acad. Sci. $110,14040-14047$.

Scientists for Science-Based Policy, 2020. Statement to Restore Science-Based Policy in Government. Concerned Members of the U.S. National Academy of Sciences: Available at: https://scientistsforsciencebasedpolicy.org/.

Spear, L., 2000. Neurobehavioral changes in adolescence. Curr. Direct. Psychol. Sci. 9 (4), 111-114.

State of Science Index Survey, 2018. Available at: https://www.3m.com/3M/en_US/ state-of-science-index-survey/.

Van Der Bles, A.M., van der Linden, S., Freeman, A.L., Spiegelhalter, D.J., 2020. The effects of communicating uncertainty on public trust in facts and numbers. Proc. Natl. Acad. Sci. 117 (14), 7672-7683.

Wilinson-Ryan, T., 2020. Our Minds aren't Equipped for This Kind of Reopening. The Atlantic (6 July), https://www.theatlantic.com/ideas/archive/2020/07/ reopening-psychological-morass/613858/.

Wright, S.E., 1993. Blaming the victim, blaming society or blaming the discipline: fixing responsibility for poverty and homelessness. Sociol. Quart. 34, 1-16.

Young, A., 2019. Channeling fisher: Randomization tests and the statistical insignificance of seemingly significant experimental results. Q. J. Econ. 134 (2), 557-598. 